Portland State University

PDXScholar

Winter 3-4-2016

\title{
On the Poverty, Rise, and Demise of International Criminal Law
}

Tiphaine Dickson

Portland State University

Follow this and additional works at: https://pdxscholar.library.pdx.edu/open_access_etds

Part of the History Commons, International Law Commons, and the International Relations Commons Let us know how access to this document benefits you.

\section{Recommended Citation}

Dickson, Tiphaine, "On the Poverty, Rise, and Demise of International Criminal Law" (2016). Dissertations and Theses. Paper 2707.

https://doi.org/10.15760/etd.2703

This Dissertation is brought to you for free and open access. It has been accepted for inclusion in Dissertations and Theses by an authorized administrator of PDXScholar. Please contact us if we can make this document more accessible: pdxscholar@pdx.edu. 
On the Poverty, Rise, and Demise of International Criminal Law

by

Tiphaine Dickson

A dissertation submitted in partial fulfillment of the requirements for the degree of

Doctor of Philosophy

in

Public Affairs and Policy

Dissertation Committee:

David Kinsella, Chair

Birol Yesilada

Christopher Shortell

Victoria Belco

Portland State University

2016 


\begin{abstract}
This dissertation in four essays critically examines the emergence of international criminal courts: their international political underpinnings, context, and the impact of their political production in relation to liberal legalism, liberal political theory, and history. The essays conceive of international criminal legal bodies both as political projects at their inception and as institutions that deny their own political provenance. The work is primarily one of political theory at the intersection of history, international relations, international criminal law, and the politics of memory. The first essay questions Nuremberg's legacy on the United States' exceptionalist view of international law and its deviant practice, while the second essay explores the relationship between exploding inequality and the triumph of the human rights movement as well as the costs of international prosecutions to the detriment of transformative politics. The third essay explores the relationship between history and international criminal courts, as well as the limits of their engagement, while the fourth examines the idea of legalism-rule following as a moral ethos-in the context of real political trials.
\end{abstract}


Pour Papa et pour Georges Rutaganda 


\section{Acknowledgments}

I wish to thank my committee members for their unwavering and unobtrusive intellectual support over the years. I have benefitted tremendously from the rigorous expectations Dr. Birol Yeşilada, but also from his unfailing kindness. He rekindled the flame of my passion for political economy. Dr. Christopher Shortell's pragmatism, humor and common sense helped me to avoid flights of intellectual fancy that would have made this dissertation impossible to complete. I am grateful for the discovery of Dr. Victoria Belco, a kindred spirit and veteran of the defense bar: she helped remind me that injustice is not limited to international tribunals, and opened a window into the magnificent self-reflexive craft of history. Dr. David Kinsella, my committee's chair, was an early champion of my work, providing me with the opportunity to develop and teach unconventional courses, and at all times treating me with often surprising collegial respect.

Thank you to Dr. Melody Rose for her salutary mentorship and support in this program when it was needed the most. Dr. Melchior Mbonimpa, a.k.a. "tonton" has played an essential role in the maintenance of my intellectual sanity and confidence, and has filled the huge gap left by my father's passing. Phil Taylor, principal investigator in the Rutaganda case, shaped my thinking about the trials and tribulations of international criminal justice, and has kept me engaged-often over my objections-with the plight of the people who suffer the most from its carelessness and cruelty. 
I am grateful for the intellectual mentors whose books have left a lasting mark on my thinking about what it means to be a scholar: Raul Hilberg, Judith Shklar, Hans Morgenthau, and Franz Neumann.

I thank my late father, Robert Dickson, for his trust, his love, and his support for my endeavors even though his paternal instincts often thought better of them.

Thanks to my children, Zoé, Mateia, Nikola, and Devon for their encouragement and for generally putting up with this project for so long. Thank you, Nona, for your patience. Хвала Бако и Деко на свему! Thank you to Agence France Presse for its erroneous wire story that prompted Dr. Aleksandar Jokić, then assistant professor of philosophy at Portland State University, to write me an email bravely attempting to correct a point in an article that I had written. Our conversation has been ongoing ever since. Sasha, my intellectual and life partner, has shown unflagging support for my work and boundless confidence in me. This dissertation would not exist without him. 


\section{Table of Contents}

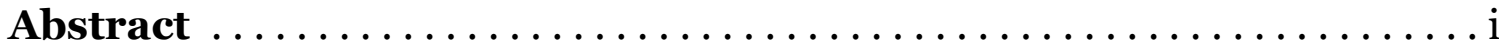

Dedication .................................. . ii

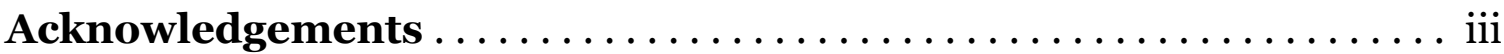

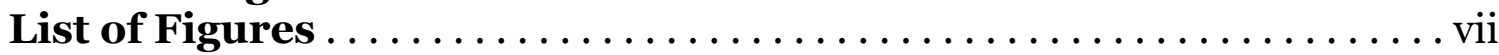

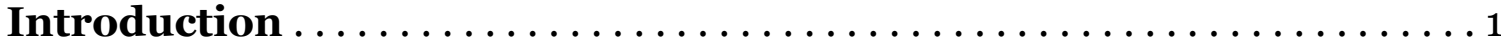

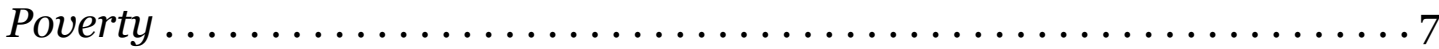

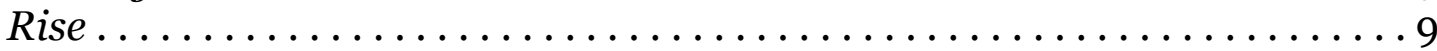

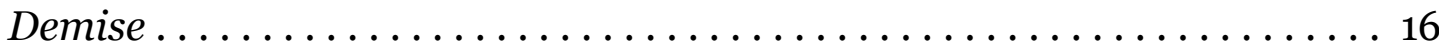

Essay 1: Reason's Tribute to Power:

International Criminal Law and International Relations . . . . . . . . 19

Flushed With Victory and Stung With Injury . . . . . . . . . . . . . . . 19

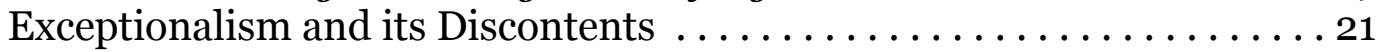

Stay the Hand of Vengeance? . . . . . . . . . . . . . . . . . 26

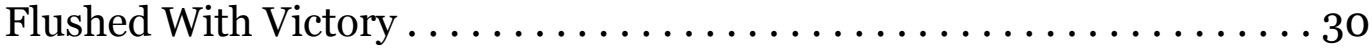

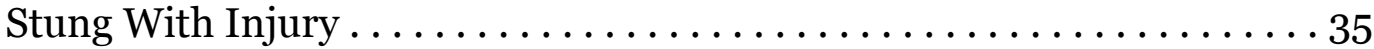

Power and Law: Pessimism of the Intellect, Optimism of the Will . . . . . 45 We, the People and the World: American Liberalism's

Troubled Relationship with International Law . . . . . . . . . . . . . . 61

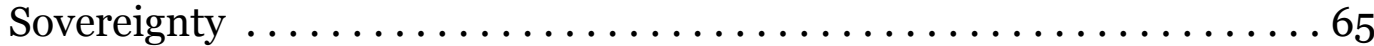

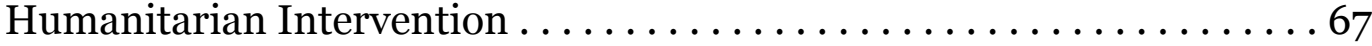

The Problem of Legalism . . . . . . . . . . . . . . . . . . . 73

Essay 2: The Costs of International Criminal Law . . . . . . . . . 75

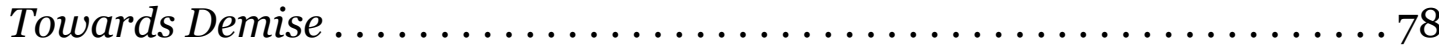

The Politics of Human Rights . . . . . . . . . . . . . . . 86

Holocaust Memory in America . . . . . . . . . . . . . . . . . . . 94

Neoliberalism, Human Rights, and International Criminal Law . . . . . . 101

(A) Economics and Inequality in American Intellectual History . . . . . 104

(B) Powerless Companions and Neoliberal Stooges . . . . . . . . . . . . . 109

(C) Crafting a Via Media: Reckless Opportunists . . . . . . . . . . . . 112

(D) Schindler's Social Darwinism . . . . . . . . . . . . . . . . . . 119

Essay 3: "The World's Court of Justice":

A Historiography of War Crimes Prosecutions . . . . . . . . . . . . 129

The Gavel of History . . . . . . . . . . . . . . . . . . . . . . . . . 129

Law in History . . . . . . . . . . . . . . . . . . . . . . . . 131

History in Law . . . . . . . . . . . . . . . . . . . . . . . . 135

A Brief History of the ICTY . . . . . . . . . . . . . . . . . 137

Trying History . . . . . . . . . . . . . . . . . . . . . . . . 143

The Political Quality of History in International War Crimes Trials . . . . 160 History in International Relations and Academic International

Criminal Law . . . . . . . . . . . . . . . . . . . . . . . . . . . . . . . . 174 
The Dangers of Obiter Dicta ........................... 181

Essay 4: Shklar's Legalism and the Liberal Paradox ............ 184

Legalism's Interdisciplinary Promise . ......................184

Shklar and the Nouveaux Legalists . . . . . . . . . . . . . . . . . . 195

Legalism in the Trenches ...........................204

Legalism and the Emergence of International Criminal Law ......... . 217

Legalism, International Politics, and the Politics of Memory . . . . . . . . . 222

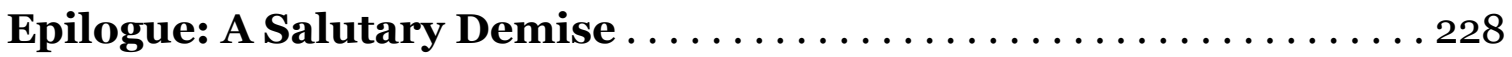

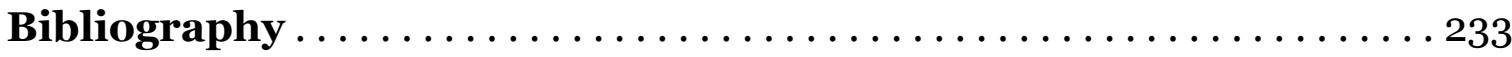




\section{List of Figures}

Figure 1: Unions and Shared Prosperity $\ldots \ldots \ldots \ldots \ldots \ldots \ldots \ldots \ldots . \ldots . \ldots$ 


\section{Introduction}

"To persons of a more skeptical turn of mind, honest criticism is not a form of destructiveness. On the contrary, it is the natural form of intellectual discourse, seen as a shared enterprise of argument and counter-argument." 1

The four essays that follow critically examine the emergence of international criminal courts: their international political underpinnings, context, and the impact of their political production in relation to liberal legalism, liberal political theory, and history. The essays conceive of international criminal legal bodies both as political projects at their inception (at least) and as institutions that deny their own political provenance. The work is one of political theory at the intersection of international relations, international criminal law, history, and the politics of memory that explores the political nature and effects of these prosecutions in their historical context.

Political theory can, and perhaps indeed it should, provide unsettling insights into and mount uncomfortable challenges against conventional wisdom. These essays certainly reflect the disposition of a skeptic, and do not hesitate to critically examine entrenched ideas, ideologies, and in some cases, dogma contained in the academic-as well as judicial, middlebrow and activistproduction in international criminal law and what I argue are its necessary corollaries, human rights, international relations and the new and perplexing conduct of war. These themes are obviously quite broad, but if any overarching

${ }_{1}^{1}$ Judith Shklar, Legalism : Law, Morals, and Political Trials, (Boston : Harvard University Press, 1986), 222. 
strands can be found in these essays it is first a concern for epistemic integrity, as well as an examination across broader issues with the way the concept of justice is understood, deployed, argued, and the validity of those facts employed to support it. Justice is one of those capacious and bedeviling political concepts, debated from (at least as far as the Western World is concerned) classical antiquity to the current time, without any resolution of the main controversies anywhere in sight. These essays will not flatter themselves with any claim to originality where the definition of justice is concerned. Rather, they question what actually existing international justice is, what it does, and how it does it, and critically examine what is meant when the concept is used as part of a political claim. Is justice a procedural matter, like the establishment of Western-style legalist war crimes tribunals in the wake of Word War II; is it economic justice; is it the justice of the execution of a big name terrorist; and do judicial institutions, when trying international criminal cases enjoy a much wider jurisdiction than domestic courts, with the felt duty to write a definitive history of the nations and conflicts that generated the crimes for which individual defendants who stand before them are accused? Do these initiatives help or hinder economic justice and solidarity at home and abroad?

The question of justice, in particular when viewed from the perspective of American foreign policy, or the Anglo-American legal model that roughly governs the new institutions of international criminal law, inevitably leads to an encounter with liberalism, a strain of political theory that has known, even in its narrower focus on the law, many variants since as early as the $17^{\text {th }}$ century when 
Hobbes and Locke presented it with such eloquence and urgency. The idea of law-the rules, the judge, the enforcement of legal sanctions-has been a central part of liberalism from the start. For liberals, political power, distrusted, and viewed as arbitrary, ought to be fenced in, and dissolved into legal relationships. In the political sphere, and perhaps even more so in the actual practice of law, this may constitute an ideology that prevents the search for the actual locus of political power-as it continues to exist, notwithstanding a constitution or a statute adopted by a Security Council resolution-thus rendering more secure its actual holders. Power, as Franz Neumann argues, "cannot be dissolved in law.”2 In classical liberalism, law stands of course for life, for liberty, and for property (even in the French Revolution), but it also stands-though often quite hypocritically in practice-for equality. If power is not equally shared as a result of the establishment of law, what of the legitimate expectation of equality, both in the conduct of international relations through majoritarian institutions and in the trials of individuals deprived of hearings in their own sovereign states?

Post-cold war liberalism emerged triumphant in the 1990s, offering the peace dividend, greater freedom and prosperity, as well as various sanguine conceptions of international law to be enjoyed in a world of liberal states. Among the most successful exponents of such ideas were scholars like Anne-Marie Slaughter who to her credit anticipated a critique of her distinction between liberal and illiberal states as reminiscent of $19^{\text {th }}$ century distinctions between

\footnotetext{
${ }^{2}$ Franz Neumann, The Democratic and Authoritarian State : Essays in Political and Legal Theory, Herbert Marcuse, ed., (Glencoe, IL : The Free Press, 1957), 7.
} 
civilized and uncivilized nations. ${ }^{3}$ She admitted that time would tell whether the distinction might be abused. Ostensibly liberal institutions such as international criminal courts, or other kinds of human rights regimes and advocacy, in their single-minded prosecutorial determination to put an end to some other kind of injustice, failed to understand, or perhaps simply discarded "for the sake of cause," basic liberal underpinnings of justice. Thus, they rode roughshod over those very cornerstone liberal principles flowing from the commitment to individual freedom: the presumption of innocence, the principle of legality, the right to fair trials, or something like due process, such as the equality of arms, leading to a state of affairs where liberal intentions, backed by the power of liberal states, led to quite illiberal proceedings and illiberal results.

Inspired by Robert Jackson's opening statement at the Nuremberg trial, the first essay, “Reason's Tribute to Power: International Criminal Law and International Relations" examines what is left, in the U.S. conduct of war, international relations and its conception of justice, of that magnificent oratory. Could power pay tribute to reason, by a nation stung with injury, in the wake of the terrorist attacks of September $11^{\text {th }}$ 2001? The focus of the inquiry is the manner in which the killing of Osama bin Laden or drone strikes against American citizens are carried out: is the appropriate realm of justification morality or legality, and what kind of law for what kind of target? This new warand perhaps also the phenomenon of American exceptionalism-has blurred the

\footnotetext{
${ }^{3}$ Anne-Marie Slaughter, "International Law in a World of Liberal States" European Journal of International Law, 6(1995): 503-538, 506.
} 
distinction between criminal and enemy leading to an uncomfortable normative position that sits uneasily with liberal principles.

The second essay, "The Costs of International Criminal Law" introduces the current gloomy state of scholarship on the phenomenon of international criminal law-a Götterdämmerung slash hangover after the jubilant years of ad hoc court establishment and the creation of the International Criminal Court (ICC). The analysis of an exemplar of the current disaffected mood, Mark Osiel, known for his work on memory of atrocities, leads to a discussion of both the historical rise of the human rights movement, as well as the coincidence of the rise of inequality in the U.S. at the same time. The human rights movement has been unable or unwilling to tackle poverty and economic injustice and instead has devoted its energy to the pursuit of streamlined, minimal issues, primarily in the prevention and punishment of atrocities. While the human rights and international criminal law movements have had some modest successes in this fight against summum malum, they have failed in articulating and much less advocating wider collective projects of solidarity. Some prominent rights activists have argued that economic rights undermine more important rights, such as political, or negative, or "first-generation rights," yet they have failed to defend those very rights in practice, and in particular in institutions of international criminal law.

The International Criminal Tribunal for the former Yugoslavia (ICTY), and the International Criminal Tribunal for Rwanda (ICTR), established by the Security Council of the United Nations in 1993 and 1994, respectively, faced the 
already daunting task of carrying out complex criminal prosecutions, with little jurisprudential guidance, in often extremely unfavorable conditions. Despite the innumerable practical, legal, financial and political challenges these institutions faced, they chose to take on an additional and unnecessary responsibility for which they were woefully ill-equipped: writing history. The third essay, "The World's Court of Justice: A Historiography of War Crimes Prosecutions" explores the incompatibility between the craft of history and institutions of international criminal law, and argues that court written history degrades both. Moreover, contrary to the tribunals' claims that their writing history in the context of the criminal prosecution of individuals serves to combat denial, the ICTY in particular contribute to precisely such historical distortions in the context of World War II atrocities.

The fourth essay, "Shklar's Legalism and the Liberal Paradox" examines Judith Shklar's Legalism in light of the paradox that emerges clearly from a lawbased approach to international crises that ought to be evaluated on the basis of whether the judicial initiative-the cases examined are primarily drawn from ad hoc U.N. Security Council tribunals-promote, in Shklar's words, “decent politics". The question of whether this notion is exclusively related to liberalism, and whether it may run contrary to the role of defense counsel in such trialsdeeply anchored in the liberal tradition of the protection of individual liberty, and yet confronted to the politics of international criminal law and international relations, however theorized-is fundamental, as "decent politics" compete with the legalistic imperatives of the defense, and the liberal foundation of the legal 
systems from which U.N. trials have emerged. Legalism provides a theoretical thread to examine the emergence of international criminal trials as well as the relation between the universality of law and history and the politics of memory, which figure prominently as political phenomena in these trials, but which may run contrary to the liberalism inherent in the legalist form.

\section{Poverty}

A note on the title of this dissertation in four essays On the Poverty, Rise and Demise of International Criminal Law is in order. "Poverty" is of course a nod to Karl Marx's retort to anarchist Pierre-Joseph Proudhon's The System of Economic Contradictions: The Philosophy of Poverty, cleverly titled The Poverty of Philosophy. As Marx contests Proudhon's abilities both in philosophy and in economics, so too I argue that the philosophical and economic bases of the broader human rights movement and institutions of international criminal law are less compelling, brilliant and hopeful than their proponents would have us believe. Proudhon's anti-statism makes him a useful foil for my own Poverty, as the phenomena under study have challenged, and for a time, at least, prevailed over the idea of sovereignty (of some states) through the creation of international or hybrid institutions that prosecute individual citizens of sovereign states, humanitarian intervention, or even drone strikes. Marx’s original “mercilessly sarcastic" 4 critique of Proudhon's work was written in French to ensure the target

\footnotetext{
4 Leszek Kolakowsi, Main Currents of Marxism, (New York: Norton, 2005), 172.
} 
of his ire would readily comprehend his acid "observations." 5 At the risk of appearing to indulge in playful, almost post-modern etymological fancy, I point out that Marx's French title is "Misère de la philosophie," where "misery" (or "miserable" or "wretched") was a synonym of "miser" until the $16^{\text {th }}$ century, when the meaning shifted to account for the presumed unhappiness of those who hoard wealth. International criminal law has been miserly, delivering surprisingly little for any of its constituencies. Those of a pro-prosecution bent will bemoan the (low) single digit conviction rate before the International Criminal Court, others may be concerned by the International Criminal Tribunal for the former Yugoslavia's carving out exceptionally liberal standards of intent for a crime as stigmatizing as genocide, while still others may wonder, more broadly, whether the turn to international human rights and international criminal law has not adversely impacted previously held projects of transformative politics.

The title also reflects three tenses of my own intellectual life. I began to think of these issues in the early 1990 os while still in law school at the Université du Québec à Montréal. An ambitious new hire, who defended his Ph.D while I was his student, hired me as a research assistant. He was, at least for me, the future criminal defense lawyer, distressingly enthusiastic about something called "international human rights," and tried to get me interested in the not-yetexisting "field" of international criminal law. I resisted, not seeing anything that could usefully be written or argued about what seemed like a quasi-legal regime with apparently no enforceable rights for defendants. Then the ICTY was

\footnotetext{
5 David McLellan, Karl Marx : Selected Writings, (Oxford: Oxford, 1977), 195-213.
} 
established, and my well-connected professor, who had studied law after a career in journalism and political engagement, received some sort of contract to contribute to deliberations about the rules of evidence and procedure from the perspective of the defense. After carrying out research on the Nuremberg trial, I met with him to discuss my findings, as well as my concerns. The presumption of innocence would be difficult to ensure, I thought, and I expressed concern that rules of evidence ought not be relaxed for charges of sexual violence, in particular as the war had already generated incredible resentments, causing me to fear the potential of unreliable testimony in exactly those instances where rapes had been committed, to avenge the crimes of-not necessarily the accused-but any other soldier, militiaman, or guard of the same ethnic group as the rapist(s). The response I received was surprising: I was told by one who identified himself as being on the defense side of things, not to be imposing Western common law on an international proceeding, as if I had been promoting some Anglo-American legalistic imperialism against the wretched of the earth. His statement shocked me by the way it was framed and I realized that this portended quite poorly for the new tribunal, especially from the perspective of individual rights. I witnessed the poverty of international criminal law at the creation.

\section{Rise}

As for the rise of international criminal law, suffice it to say that I did go on to become a busy criminal defense lawyer in the trenches, writing articles for 
my Bar colleagues when time permitted, while my professor, William Schabas, ascended the Olympus of human rights and genocide scholarship, as his 30 page curriculum vitae and half dozen honoris causae can attest. I was content in my practice, and planned not only to return to school to deepen my study of legal theory, but held the ambition of one day being named a judge. Circumstances, however, upended these plans as I was recruited to the defense team on one of the first ever cases prosecuting genocide as a result of my published work on the disclosure of evidence. Thus, I became in January 1997 co-counsel for Georges Rutaganda before the International Criminal Tribunal for Rwanda, in Arusha, Tanzania, and was appointed lead counsel in September of that year after his Belgian counsel essentially disappeared. This was the first year that individuals were charged with genocide; this was the rise of international criminal law. There is much that I could catalogue of my experience, from the humorous-being prevented from returning to the courtroom after a break by Hillary Clinton's Secret Service detail and taking an unguarded back entrance instead-to the daily Kafkaesque violations of the rights of my client. I wish instead to relate the issue of how international criminal law, during its ascent, blocked the investigation of one of the most causally significant events in 1994 Rwanda.

The consensus view is that the spark that set off the explosion in Rwanda in 1994 was the shooting down of the plane carrying presidents Habyarimana of Rwanda and Ntaryamira of Burundi, the Rwandan Army chief of staff, officials close to the presidents and the entire French crew. 
More than twenty years after the catastrophic shoot-down of April 6th 1994, there have been no criminal prosecution, no civil sanctions, and no diplomatic consequences to speak of in relation to this crime. It is as if the airplane had simply crashed by itself, while the killings then started. As cruel as this declaration may appear, it conforms exactly to the thesis adopted by the Prosecutor at the ICTR in the charges brought against Georges Rutaganda, my client:

The 6th of April 1994, an airplane carrying President Juvenal Habyarimana of Rwanda, and President Cyprien Ntaryamira of Burundi crashed at the Kigali airport killing all aboard. Following the deaths of the two presidents, the generalized political and ethnic killings began in Kigali and then spread to other parts of Rwanda. ${ }^{6}$

The vocabulary of the ICTR Prosecutor does not indicate a great desire to see things as they are: the plane "crashed". Two presidents of two countries so torn by wars and coups d'états, likely to return to a bloody war, were "dead," as simple as that. It is not inaccurate to assert that the plane crashed. It is, however, quite incredible that an institution described as judicial and established by the Security Council of the United Nations would neglect to mention that before the plane crashed, it was blown out of the sky by two SAM-16 missiles.

The ICTR had all the judicial power and technical means required to initiate and carry out a thorough investigation of this terrorist act that triggered such nightmarish consequences. Yet its causes seem to be of astonishingly little interest to this organ of the UNSC, which was also responsible for the UNAMIR

\footnotetext{
${ }_{6}$ Prosecutor v. Georges Anderson Nderubumwe Rutaganda, ICTR 96-3-I, Indictment.
} 
force in Kigali at the time of the attack, present on the ground in Kigali at the time of the shoot-down. The importance of the shoot-down had not, however, escaped my attention. Already on the 7th of February 1997, I argued before Chamber I of the ICTR for the disclosure of all evidence obtained by Prosecution investigations into the shoot-down of the presidential plane or, alternatively, in the event that no such investigation had taken place, to order that the Prosecution proceed immediately to initiate such an investigation. The response by the Deputy Prosecutor was surprising:

Our responsibility and mandate is not to investigate plane crashes. That's not really our function. Therefore, I would categorically answer this question by saying that, first, we don't have any such investigation. We have not made any such investigation and we don't have any reports. And, secondly, it is not our function, it is not our mandate, to investigate plane crashes or presidents, vice-presidents, or whoever it is. And, therefore, this is really a matter not within our province. 7

That was in February 1997. On the 1st of March 2000, the Canadian daily, National Post, revealed that investigations into the shoot-down had been carried out by the Prosecution starting in $1996,{ }^{8}$ that is, before the Prosecutor had denied it, categorically and on his oath of office, during the trial of Georges Rutaganda. The information obtained by The Post showed that investigations had in fact been fruitful: two witnesses from Kagame's elite unit, “The Network," had been located and they affirmed that the shoot-down was the work of the RPF, in collaboration with a foreign country. The journalist from The Post had acquired two

7 Prosecutor $v$. Rutaganda, ICTR 96-3-T, translated from French language transcripts of February $7^{\text {th }}, 1997$, pp. 44-5.

8 “Explosive Leak on Rwanda Genocide," Steven Edwards, National Post, March 1st 2000, page 1. 
documents: the so-called "Hourigan Report," as well as an unsigned letter, detailing the testimonies of the members of "The Network".

The first confidential report was written for the Office of Internal Investigations of the United Nations by a former investigator for the Prosecutor's Office 9 expressing frustration with the fact that he was prohibited from continuing the investigation into the shoot-down, despite the fact that it was progressing well and following Prosecutor Arbour's initial enthusiasm about the new developments. Suddenly, however, she brutally shut down the investigation. It had been closed just as it was gathering credible evidence about the perpetrators of the shoot-down.

Thus, investigation was shut down, despite it having located new witnesses who were ready to talk. Their testimony would have completely overturned the conventional narrative regarding the shoot-down as an act perpetrated by "extremist Hutus" to liquidate a too-moderate Habyarimana whose plans were to establish the institutions set forth in the Arusha Accords. Instead, his assassination would trigger a pre-planned genocide against the Tutsi people of Rwanda.

What if the investigation that was shut down had revealed that the RPF had brought down the presidential plane? What would have been the political consequences? In his testimony in the case Prosecutor $v$ Rutaganda, Belgian

\footnotetext{
9 Michael Hourigan, Australian lawyer, employed by the Prosecution of the ICTR in the first years of operation of the Tribunal. Barrie Collins, Rwanda 1994: The Myth of the Akazu Genocide Conspiracy and its Consequences, London, Palgrave MacMillan, 2014, 30-32.
} 
Professor and Rwanda specialist Filip Reyntjens, called by the prosecution as an expert witness, conceded during the cross examination that:

The Arusha Accords gave a great deal to the RPF. They could have clearly gained even more if they had carried on with the war to its end, which in the end they did, but which they certainly could not have done if they had no good pretext.

Now, I am not at all suggesting that the RPF had been looking for this pretext, because this pretext would have meant shooting down of the presidential plane and we do not know, today, who carried out this shoot down." (emphasis added) ${ }^{10}$

We now know that at the time Professor Reyntjens was testifying, the Prosecutor was indeed in possession of evidence pointing to the RPF as the responsible party for the shoot-down. In light of Reyntjens' reasoning, serious problems emerge.

First, contrary to the assertion by the Deputy Prosecutor in February 1997, the identity of the perpetrators of the shoot-down was relevant. More significantly, the Prosecution's fundamental thesis-that President Habyarimana, the MRND, the general staff of the Rwandan Armed Forces and other Hutu "extremists," failed to negotiate for peace in good faith, because they did not want to share power with the RPF-collapses completely. In place of this entrenched conventional account, a competing theory emerges as plausible. The RPF may have shot down the plane in order to create a pretext for breaking the ceasefire, continuing armed hostilities, and take advantage of the predictable chaos

1o Prosecutor v. Rutaganda, ICTR 96-3-T, French language transcripts of November 24th 1997, pages 19-20. 
following the shock created by the President's assassination to take over the entire country militarily.

And so the massacres began. We know what then unfurled, and how these killings continued across a macabre path towards the Congo. Five million, six million human lives were lost since the invasion of Rwanda in 1990. Where is the Tribunal for the Congolese victims, for the Hutus slaughtered in the refugee camps in the ex-Zaire? What then would be the legal consequences to be drawn from the fact that the Prosecutor's investigations revealed that the presidential plane was shot down by the RPF? Professor Reyntjens again gives us a line of thinking that is of essential importance for understanding not only the Rwandan catastrophe, but also the real reasons why an investigation that may have begun in good faith could end up so bungled:

But there would also exists a legal interest. Those who brought down this plane knew very well what the consequences of this shoot-down would be and in this case they would bear a legal responsibility, and I'm not saying political, now, but legal, for the genocide. Because they, knowing full well what the consequences are, would have unleashed a genocide. ${ }^{11}$

Despite this evidence presented at his trial, the judgment condemning Georges Rutaganda made note only of a "plane crash". The shoot-down is invisible, its victims are demonized, and the fact of the shoot-down would only serve as a point of reference, in time, marking the beginning of the genocide.

${ }^{11}$ Prosecutor $v$. Rutaganda, ICTR 96-3-T, French language transcripts of the $24^{\text {th }}$ of November 1997, pp. 113-114. 


\section{Demise}

Thus, perhaps understandably, began my struggle with legalism confronted to the astonishing-and too often cynical, dishonest and unfairrealpolitik in and outside the courtroom. In 2004, the Security Council of the United Nations announced its completion strategy for the two ad hoc courts; the new International Criminal Court would now carry the weight of international prosecutions.

The legacy of the ICTR, in particular, is marred by the shocking fact that eleven acquitted defendants remain in a safe house in Arusha, Tanzania, as the institution has proven itself unwilling or unable to secure the kind of arrangements with U.N. member states that it had succeeded in doing to house the convicted. It is impossible for these individuals to return to Rwanda without being prosecuted anew, ${ }^{12}$ and many states where their families reside legally have refused to grant visas for these people. One acquitted man has been living in the safe house since 2004. It is as if no thought was given to the eventuality of acquittals. ${ }^{13}$

The ICTR heard its last appeal in December 2015. The electronic archives are scandalously incomplete, particularly in the case of my client. There is tremendous concern that the record of the proceedings of this now defunct body is not kept with anything resembling archival integrity.

\footnotetext{
12 James Karuhanga, "ICTR Can Return To Rwanda But May Still Be Charged: RPF," New Times, Kigali, January $18^{\text {th }}, 2016$.

13 Caroline Buisman and Kate Gibson, "Acquitted by Law, Prosecuted by Propaganda," Justice in Conflict http://justiceinconflict.org/2014/o3/31/acquitted-by-law-prosecuted-by-propaganda/.
} 
In the wake of September $11^{\text {th }}$ 2001, it was clear that a serious challenge to the ICC's legitimacy had been presented by the "unsigning" of the Rome Statute by President George W. Bush. State members of the ICC could not agree on a definition of the crime of aggression-the supreme international crime, as per the Nuremberg tribunal-until 2010, but even then, with the influence of the U.S. "observer" delegation, it became possible for states to "opt out" of jurisdiction over the offence. The ICC appeared to have regained prestige and importance in 2011 when it issued indictments against Muammar Gaddafi, but the fact and the manner of his subsequent murder, as well as the deterioration of the security situation and state apparatus in Libya left a bitter, decidedly non-Nuremberg-like taste. Grumbling about the ICC's outcomes-and exclusive prosecution of Africans-has grown louder. In a late 2014 New York Times debate, Professor Daniel Abebe calculated that the ICC's budget $-\$ 1$ billion since 2002-could have fed 600 million people or vaccinated 1.7 billion. He makes the following politically decent point:

Pouring more money into the I.C.C. or expanding its powers won't overcome the constraints of international politics. Investing in education and health care in Africa is a better use of limited resources. In the end, if the supporters of the I.C.C. really think it is necessary, they have the burden of explaining why two convictions from a flawed court are worth $\$ 1$ billion. ${ }^{14}$

\footnotetext{
14 Daniel Abebe, “I.C.C.'s Dismal Record Comes at Too High a Price,” The New York Times, December 11 ${ }^{\text {th }}, 2014$, http://www.nytimes.com/roomfordebate/2014/12/11/do-we-need-theinternational-criminal-court/iccs-dismal-record-comes-at-too-high-a-price
} 
The false dichotomy between basic human needs and the quest for the prosecution of atrocity crimes and the most egregious human rights violators has hindered not only the proper conduct of criminal justice and achieved illiberal results, but has also degraded concrete solidarity projects at home and abroad. Perhaps then, as these essays explore, the prospect of international criminal law's demise is not such a dire prospect, after all. 


\title{
Essay 1: Reason's Tribute to Power: International Criminal Law and International Relations
}

\author{
"If you doubt America's commitment-or mine-to see that justice is done, just \\ ask Osama bin Laden. (Applause.)"15
}

Flushed With Victory and Stung With Injury

Four decades after their accomplishment, it seemed that the revolutionary prosecutions of individuals under international law at Nuremberg and Tokyo would, in the end, remain historical aberrations. Described variously as forms of victor's justice, ${ }^{16}$ or sui generis political trials-for late political theorist Judith Shklar, writing about Nuremberg, they were acceptable to the extent that they might bring about "decent politics," 17 while for Tokyo Judge Rahabinod Pal, they were means to curtail and contain self-determination and decolonialization ${ }^{18}-$ over time, and with the cold war unable to produce anything like the precedent of Nuremberg, "growing” as Geoffrey Best put it, "ever fainter,"19 it appeared that the revolution of post World War II trials would remain childless. Ethiopia's 1949 attempt to extradite Italian marshals Pietro Badiglio and Rodolfo Graziani for

\footnotetext{
15 "Remarks of President Barack Obama-State of the Union Address as Delivered," January $12^{\text {th }}$, 2016, https://www.whitehouse.gov/the-press-office/2016/01/12/remarks-president-barackobama-\%E2\%80\%93-prepared-delivery-state-union-address

${ }^{16}$ Danilo Zolo, Victors' Justice: From Nuremberg to Baghdad, (London: Verso, 2009) 27-29.

${ }_{17}$ Judith N. Shklar, Legalism, (Cambridge: Harvard University Press, 1964), 145.

${ }^{18}$ Kirsten Sellars, "Imperfect Justice at Nuremberg and Tokyo," EJIL (2010), Vol. 21 No. 4, 10851102, 1096.

19 Geoffrey Best, cited in Sellars, "Imperfect Justice at Nuremberg and Tokyo," 1086.
} 
war crimes before an international court governed by the Nuremberg principles ${ }^{20}$ failed, ${ }^{21}$ while Hans Kelsen expressed the hope that Nuremberg would not create a precedent. ${ }^{22}$ Hedley Bull argued that the selectivity of the war crimes courts would cloud their symbolic value, and that it would be best to refrain from creating bodies that would "reflect the values of the presently prevailing great powers" ${ }^{23}$ without necessarily corresponding to a moral order yet to be built. ${ }^{24}$

Once the Security Council established the International Criminal Tribunal for the Former Yugoslavia (ICTY), shortly followed by the creation of the International Criminal Tribunal for Rwanda (ICTR), unthinkable during the cold war, but suddenly possible as a result of the radically different political conditions that emerged after its end, enthusiasm and support for international criminal tribunals and prosecutions of individuals under international law became ubiquitous in the scholarly literature. The disciplines from which this praise emanated were not limited to international law: historians, political scientists, political theorists, ethnographers, as well as large swaths of the humanities had something to contribute to the discourse of virtuous triumph. Finally civilization had reached, if not Fukuyama's End of History, at least a

\footnotetext{
${ }^{20}$ Charter of the International Military Tribunal, in Agreement for the Prosecution and Punishment of the Major War Criminals of the European Axis, Aug. 8, 1945, 59 Stat. 1544, 82 UNTS 279.

${ }^{21}$ Zolo, Victors' Justice: From Nuremberg to Baghdad, 27.

${ }_{22}$ Hans Kelsen, "Will the Judgment in the Nuremberg Trial Constitute a Precedent in International Law?” International Law Quarterly 1 (2), 1947; Zolo, 18.

23 Hedley Bull, The Anarchical Society: A Study of Order in World Politics (New York, NY: Columbia University Press, 1977), 304; Justice in International Relations. 1983-84 Hagey Lectures, University of Waterloo (Waterloo, Australia: University of Waterloo Press); Jonathan Graubart (2010), "Rendering Global Criminal Law an Instrument of Power: Pragmatic Legalism and Global Tribunals" Journal of Human Rights, 9:4, 409-426, 411. 24 Ibid.
} 
promise of previously unattainable universal justice, and barring that, personal meaning for the romantics who'd finally found their academic Spanish Civil

War. ${ }^{25}$

\section{Exceptionalism and its Discontents}

What is to be done with a project that seeks to engage with the politics of international criminal law and that does not assume that the normative enthusiasm, claims to institutional legitimacy, or policy positions expressed by much of the scholarly literature ${ }^{26}$ are unproblematic? A first question concerns the nature of what is being analyzed: international law, though a legal project, and accordingly susceptible to being studied strictly as such, is also undeniably the result of politics. Historically, the theoretical study of law has always been closely associated to philosophy and political theory, and from Plato's Laws to contemporary critical legal theory, it has been clear, for the most part, that the study of the law has not been the study of just one thing, but is rather, as writes Ian Ward, “a critical and an interdisciplinary exercise.”27 Critical legal scholarship, according to Ward, disputes "the assertion that law can be

25 Corey Robin, Fear: The History of a Political Idea, (New York: Oxford University Press, 2004) 147-148. See, too, Carl Schmitt's Political Romanticism, in particular as the idea is applied to contemporaries such as the late Christopher Hitchens by David Runciman, "It's Been a Lot of Fun," London Review of Books, 24 June 2010, <http://www.lrb.co.uk/v32/n12/davidrunciman/its-been-a-lot-of-fun>.

${ }^{26}$ See, inter alia: K. Abbott, Robert Keohane, Andrew Moravscik A, et al. (2000) "The concept of legalization," International Organization 54(3): 401-419; Yves Beigbeder, (2002) Judging Criminal Leaders: The Slow Erosion of Impunity. The Hague: Kluwer Law International; AnneMarie Slaughter, (1995) "International law in a world of liberal states," European Journal of International Law 6(4): 503-538; (2003) A global community of courts. Harvard International Law Journal 44(1): 191-220; (2004) A New World Order. Princeton, NJ: Princeton University Press; (2007) The Idea that is America: Keeping Faith with Our Values in a Dangerous World. New York: Basic Books.

27 Ian Ward, Introduction to Critical Legal Theory, (London: Cavendish Publishing, 1998), v. 
understood, that it can be founded, in one particular theory or one particular discipline or methodology." ${ }^{28}$ This view takes the position that law is not a science (or at least not just a science), a stance that critical approaches are hardly alone in defending. As a recent symposium on the methodology of international law, edited by Steven R. Ratner and Anne-Marie Slaughter ${ }^{29}$ in the American Journal of International Law illustrates, "mainstream” legal scholarship has all but abandoned the exclusive theoretical commitment to a scientific study of law, opting instead for policy relevance, $3^{30}$ affecting the conduct of international decision makers, ${ }^{31}$ and studying the intersection of international relations and international law (or international law as a subset of international relations). 32

While "mainstream" approaches to international law have heeded Hans Morgenthau's 1940 call for a closer connection between the "science" of international law and its subject matter,33 its approach to the examination and analysis of international criminal law is largely rooted in a faith that liberal judicial models produce justice. 34 As questioning faith generated the ability to develop scientific enquiry in the Enlightenment, so, too, has the abandonment of the scientific approach to law apparently favored the conditions for a return to

\footnotetext{
28 Ibid.

29 Steven R. Ratner and Anne-Marie Slaughter, "Appraising the Methods of International Law: a Prospectus for Readers," The American Journal of International Law, Vol. 93, No. 2 (Apr., 1999), pp. 291-302

$3^{30}$ See the New Haven School, Ratner and Slaughter, "Appraising the Methods of International Law: a Prospectus for Readers,"293.

${ }^{31}$ Ibid., as in the International Legal Process School, 294.

$3^{2}$ Ibid.

33 Hans J. Morgenthau, "Positivism, Functionalism, and International Law," 34 AJIL 260, 261 (1940).

34 Graubart, "Rendering Global Criminal Law an Instrument of Power: Pragmatic Legalism and Global Tribunals," 411.
} 
faith, ideology, and the cloaking of power with the discourse and vocabulary of justice.

Anne-Marie Slaughter's A New World Order displays the kind of optimism towards post-cold war international law, and its potential to universalize American judicial values, that deserves further investigation. ${ }^{35}$ At the heart of her project, first introduced in "International Law in a World of Liberal States," is the idea that American judicial governance-in the tradition of Marbury v. Madison-is not only desirable at an international level, but that it has already taken root as an international "community of courts" that act to limit centralized authority. It is as powerful a suggestion as it is provocative, and indeed curious: the legal (and symbolic) power of Marbury is predicated on a central, hierarchically superior legal text, the U.S. Constitution, yet no such document, or constitutional regime exists internationally. ${ }^{36}$ As Nikolas Rajkovic notes, the symbolic force of the American constitutional order is fully deployed within the "proliferation of powerful international courts," while the "rule of no one," the rule of higher law establishing a system of judicial review (and referring to the idea that no one is above the law, as well as to the concept of a government of laws, not men), is exposed,37 or to reformulate more strongly, empty.

The strength of Marbury cannot be divorced from the culturally-specific and distinctly American attachment to the U.S. Constitution, one that, as Paul W.

\footnotetext{
35 Nikolas M. Rajkovic, “'Global law' and Governmentality: Reconceptualizing the 'Rule of Law' as Rule 'Through' Law,” European Journal of International Relations, 20 (10),(2010) 1-24. ${ }^{36}$ Ibid., 9 .

37 Ibid.
} 
Kahn has argued over the years, is spiritual in nature, $3^{8}$ and results from the constitution's embodiment of the popular sovereign's act of will.39 "Not coincidentally," writes Kahn, it is precisely the belief that the constitution is a product of the sovereign will that "supports what is commonly called 'American exceptionalism."'4o Further, it is this very exceptionalism that justifies the U.S. reluctance to join international treaties, human rights conventions, to agree to the jurisdiction of international or translational courts, and to abide by their rulings. ${ }^{11}$ And yet, the Marbury ideal is the foundation upon which Slaughter's New World Order is built, one in which American values radiate outward-such as with Gary Jonathan Bass's peculiar suggestion that the American Declaration of Independence ought to apply to Bosnians ${ }^{42}$-but are not, once they are projected back through any kind of remotely functional international legal structure, accepted or welcome. And this is possible because contrary to law's rule in the United States, there is no international constitutional system in place internationally, and no enforcement beyond what states accept. That many of these treaties and international agreements are the results of successful U.S.

\footnotetext{
${ }^{8} 8$ Paul W. Kahn, The Reign of Law: Marbury $v$. Madison and the Constitution of America, (New Haven, CT: Yale University Press, 2000); The Cultural Study of Law: Reconstructing Legal Scholarship, (Chicago: University of Chicago Press: 1999); Sacred Violence: Torture, Terror, and Sovereignty, 2008; Out of Eden: Adam and Eve and the Problem of Evil, 2006; Putting Liberalism in its Place, Princeton University Press, 2004. Paul W. Kahn, Political Theology, (New York: Columbia University Press, 2011); "Criminal and Enemy in the Political Imagination," 99 The Yale Review, 2010; "Philosophy and the Politics of Unreason, 97 California Law Review, 2009; "Justice or Legitimacy," 68 Journal of Asian Studies, 2009; "Speaking Law to Power: Popular Sovereignty, Human Rights, and the New International Order," Chicago Journal of International Law, Spring 2000.

39 Paul W. Kahn, Political Theology (New York: Columbia University Press, 2011), 9.

$4^{40}$ Ibid.

${ }^{41}$ Ibid.

42 Gary Jonathan Bass, Stay the Hand of Justice: The Politics of War Crimes Tribunals

(Princeton: Princeton University Press, 2000), 22.
} 
foreign policy, and that Americans do not disagree, according to Kahn, with the substance of international human rights law, appears less paradoxical when viewed in light of the American inability to see law outside the expression of the sovereign. Absent an international sovereign-or perhaps in the presence of another sovereign, a "them" to whom "we" are related only imperfectly-the American political imagination does not see law. 43 Since the initial expression of popular sovereignty is a result of revolution, law is linked to exception. 44 American exceptionalism, for Kahn, is best understood as a variation on the theme of Carl Schmitt's exception: "Sovereign is he who decides on the exception."45

Slaughter's optimism thus seems premature, or more precisely misplaced, if the exercise is meant to construct a system of international law that applies equally to all. And perhaps, in fairness, that was not what the project sought to accomplish. While the "new world order" was witness to the emergence of lawlike bodies (the expression is Judith Shklar's) ${ }^{46}$ constraining the sovereignty of some states, the one state that predominantly decides whose sovereignty will be overridden is an exception to the universal regime as it is not held by it (though it is not, in this respect, alone). This one state, too, decides on the exception: those extreme cases of use of force and the establishment of judicial institutions governing exceptional cases arising from exceptional events. Because they are exceptional, international judicial bodies are not always created to deal with

43 Kahn, Political Theology, 10.

44 Ibid.

45 Id., 30

${ }^{46}$ Shklar, Legalism, 156. 
exceptional events; they may or may not be, in accordance with the decision of the sovereign. Schmitt was not a liberal, of course, but assuming for the sake of argument that liberal states, as conceived of in Slaughter's 1995 disclaimer regarding the manner in which her argument might be received, are in fact embodied by the U.S., it is instructive to take note of the potential for anachronistic adventurism that she makes explicit:

The very idea of a division between liberal and non-liberal States may prove distasteful to many. It is likely to recall 19th century distinctions between 'civilized' and 'uncivilized' States, rewrapped in the rhetoric of Western political values and institutions. Such distinctions summon images of an exclusive club created by the powerful to justify their dominion over the weak. Whether a liberal/non-liberal distinction is used or abused for similar purposes depends on the normative system developed to govern a world of liberal and non-liberal States. 47

And what normative system has been established that we might begin to evaluate whether distasteful $19^{\text {th }}$ century distinctions between civilized and uncivilized states, "rewrapped in the rhetoric of Western political values" have emerged? The case of international criminal law is most instructive in this respect.

Stay the Hand of Vengeance?

Scholarship on international criminal courts described previously as belonging to the "mainstream," and displaying unusual commitment and

47 Anne-Marie Slaughter, "International Law in a World of Liberal States" European Journal of International Law, 6(1995): 503-538, 506. 
optimism for a policy project (as opposed to, say, determination to understand or explain a given phenomenon) has been largely supportive of the drive toward international criminal law. Gary Jonathan Bass exemplifies this tendency in his book, Stay the Hand of Vengeance, published in 2000, in which he insists that only liberal nations adhering to due process establish war crimes trials, and insists, in particular, on American leadership-as well as, in an odd throwback to cold-war rivalry-Soviet bad faith, if not perfidy. Bass is explicit in identifying his theoretical opponents, the realists, who "argue that international relations differ from domestic politics in the lack of ruler among self-interested states." 48 Realists are in turn "mystified" by international moralizing and "contemptuous" of "utopianism."49 Bass acknowledges the many historical failures of Western states to achieve war crimes trials-this is the term he uses, though his descriptions of offences lean towards extreme acts closer in nature to crimes against humanity and genocide-on the basis of state interests, but posits that there is something distinctly legalistic about these trials, something that realism cannot grasp or account for. They are not mere purges, he states, they do not aim to dispose of enemies but to try criminals "deserving of just punishment," something realists, he writes, would be baffled by or deplore. $5^{0}$

For all his sense of justice, however, Bass repeatedly indulges in formulations that support the justness of killing without recourse to trial, whose great virtue is in not some abstract due process, and much less a vague liberal

\footnotetext{
${ }^{48}$ Bass, Stay the Hand of Vengeance, 9.

49 Ibid.

5o Ibid., 12.
} 
morality, but rather in performing the epistemic exercise that consists in evaluating actual evidence instead of determining that some individuals' lives can be expended extra-judicially: "Today, who could really say that it would be totally unjust to shoot thugs like Théoneste Bagosora or Ratko Mladic?,”51 “[Milosevic] "could have wound up like Romanian President Nicolae Ceausescu,"52 "These leaders ...are lucky to be alive.” ${ }_{53}$

Bass may be reasoning counterfactually in reference to Robert Jackson's opening statement at Nuremberg, and referring to the stirring oratory that unforgettably intoned:

That four great nations, flushed with victory and stung with injury stay the hand of vengeance and voluntarily submit their captive enemies to the judgment of the law is one of the most significant tributes that Power ever has paid to Reason. 54

Bass makes a compelling case that the views of Western leaders, in particular those of Churchill and Roosevelt, were, at least initially, strongly in favor of executing the Nazi leadership. But this is not the same as saying that Power's only means (and here, one would be well advised to read "realism") are vengeance and killing, nor that realism, or power, or even liberalism, or reason, ever considered it "just" to kill extrajudicially. That type of political theory can be found in the

${ }^{51}$ Ibid., 13.

$5^{2}$ Gary J. Bass, "Victor's Justice, Selfish Justice,” Social Research 69 (4) (2002) 1035-1044, 1039. 53 Gary Jonathan Bass, "War Crimes Tribunals," The Oxford Handbook of Law and Politics, Kenneth Whittington, R. Daniel Keleman, and Gregory A. Caldeira, eds., (Oxford: Oxford University Press, 2008), 238.

54 "Second Day, Wednesday, 11/21/1945, Part 04", in Trial of the Major War Criminals before the International Military Tribunal. Volume II. Proceedings: 11/14/1945-11/30/1945. [Official text in the English language.] Nuremberg: IMT, 1947, 98. 
Medieval just war theory, or its successor versions in those thinkers Kant called "miserable comforters" in Perpetual Peace, or finally in its contemporary exponents such as Michael Walzer. Power does not cloak its killings under the mantle of justice, as Thucydides-upon whom Bass does not hesitate to rely to show the historical reality of reprisal killings and the exterminations that the Greek wars of antiquity visited upon defeated enemies55-but on the assertion of raw power. The Melian dialogue, the most oft-cited of Thucydides' moralistic passages, shows that Athens did not consider that it possessed any claim or right or just cause over the lives of the citizens of Melos in the event of their defeat: only that they would, in the event of war, be powerless to resist mass murder and enslavement, and thus would be well advised to respond positively to Athens' request that they no longer declare neutrality, and instead join them in the Delian League. This was by all means a threat, but what it certainly was not was a realist claim that killing was right. Not right, only possible (and indeed likely), and therefore expedient. What we remember from the Melian dialogues is that the Melians made a moral-and consequentialist-case for decency in war. Today, we would describe the Melian argument as consistent with the rules of jus in bello, but at that time, and as told by Thucydides, the Melians were arguing that perhaps Athens would not forever be as powerful as it was then, and that decency in combat might eventually appear to be a custom they would be grateful to see

\footnotetext{
55 Gary Jonathan Bass, "War Crimes Tribunals," The Oxford Handbook of Law and Politics, Kenneth Whittington, R. Daniel Keleman, and Gregory A. Caldeira, eds., (Oxford: Oxford University Press, 2008), 229-230.
} 
observed by all56.

\section{Flushed With Victory}

The discursive origins of international criminal law were auspicious enough. Robert Jackson's opening statement at the Nuremberg Trial of the Major War Criminals, artfully balanced in perfect proportion the rhetorical ingredients of logos, pathos, and ethos, and memorably cast the undertaking as exceptional. It bears repeating: "That four nations, flushed with victory and stung with injury," Jackson said, "stay the hand of vengeance and voluntarily submit their captive enemies to the judgment of the law is one of the most significant tributes that Power ever has paid to Reason.” And to an important extent, it was. The allies could have followed historical precedent and inflicted a wide array of extrajudicial punishment on the vanquished. Yet for the first time, as Justice Jackson framed it, power paid tribute to reason. "Tribute," of course, in its original Latin form incarnation designated a tax, then a form of subjugation. Roman and Greek tributes were habitually paid by defeated or vassal nations to the victors or the imperial capital.57 Power, which in the case of Justice Jackson's Nuremberg oratory, represented military victory over the Axis states in World War II, would pay tribute, or choose to subordinate itself, to reason, represented by the model of a courtroom. The opposition of the courtroom to the idea of vengeance is not new, as Justice Stephen Breyer, in a keynote address to mark Yom Hashoah at

\footnotetext{
${ }^{6}$ Thucydides, History of the Peloponnesian War, trans. Rex Warner, (Harmondsworth: Penguin Books, 1972), 5.90-5.104. 57 Russell Meiggs, Review of Benjamin Dean Meritt, H. T. Wade-Gery, and Malcolm Francis McGregor 'The Athenian Tribute Lists' (1952),The Classical Review (New Series), 2 , pp 97-100 .
} 
the Capitol Rotunda in 1996, evoked Aeschylus' The Eumenides, ${ }^{8}$-in which the vengeance of the furies is thwarted by Athena's decision to hold Athens' first mythical trial for murder-as a precedent to Nuremberg's pioneering judgment of crimes against humanity. Breyer sees in Nuremberg an ending of the "Holocaust story with a fair trial, an emblem of that justice" that echoes Aeschylus: a perfect justice that is the best in the land, a "bulwark of salvation" across the empire, the mightiest in the habitable world.59 The reference hardly seems accidental. In The Eumenides, it is not, however, justice, but the goddess Athena who creates a criminal court, and it is in fact her power and authority that allows reason to displace vengeance as a preferred social solution for Athens, perhaps much as it was the power of Allied occupation, in Nuremberg, that allowed the allies to decide that reason, rather than vengeance, was the preferred international solution, in what had already become a significantly altered state of relations between major powers.

The Eumenides has also, however, been interpreted as reflecting a "dark side" of Athens, in particular in its imperial designs and practices. ${ }^{60}$ Justice Breyer, in introducing the link between Jackson's contribution to Nuremberg and Aeschylus' justice (or Athena's, in fact), does not hesitate to include her claim that the seat of justice "shall be a wall, a bulwark of salvation, wide as your land,

\footnotetext{
${ }^{8}$ Stephen Breyer, “Crimes Against Humanity: Nuremberg, 1946” (1996) 71 N.Y.U.L. Rev. 1161, 1164. 59 Id.

6o Rebecca Futo Kennedy, Athena's Justice, (New York: Peter Lang, 2008), 5-11.
} 
as your imperial state; none mightier in the habitable world." ${ }^{61}$ Here, in Breyer's oratory, Jackson represents American aspirations for international criminal law, and The Eumenides provides support for the notion that it is desirable to spread the democratic brand of justice (whether Athenian or American) abroad, as these values are inherently universal, radiating outward, as with Slaughter and Bass. That the U.S., like Athens, might be an empire, and how this relates to justice when carried out internationally, is worth examining.

Rebecca Futo Kennedy, in her study of several Greek tragedies, traces the changes in the portrayal of Athena's position on justice over a fairly short period of history (roughly of the existence of the Delian League, in the $5^{\text {th }}$ century BCE), and in relation to Athens' relations with its allies. ${ }^{62}$ She first notes the peculiar fact that The Eumenides describes the trial of Orestes, who is a summachos, translated as a non-Athenian military ally. ${ }^{63}$ At the time the play was first presented to Athenians, the only murder trials held in the Areopagus-where The Eumenides takes place-were of Athenians, and this is significant for Kennedy as the portrayal of the trial of a non-Athenian ally represents Athenian judicial hegemony in the Empire. ${ }^{64}$ Alliances in Athens required having the same friends and enemies; here Carl Schmitt looms large again. ${ }^{65}$ From The Eumenides' portrayal of the Athenian justice of 460-45o BCE, Kennedy shifts her attention to the portrayal of justice and its relation to the increasing toll that war has taken on

${ }^{61}$ I have been unable to find the translation relied upon by Justice Breyer; other translations differ somewhat, and some do not include the term (or idea of) empire.

62 Ibid.

63 Ibid., 27.

64 Ibid.

65 Ibid., 29. 
Athens, her allies, as well as her enemies, as portrayed in Sophocles' Ajax, ${ }^{66}$ set in the period of the Peloponnesian wars, and in the context of increasingly oppressive domestic rule in the years 429-412 BCE, some two decades later. Kennedy compares Thucydides' Melian dialogue-written a decade later-to the type of discourse Athena now holds in Ajax: no longer eschewing violence and vengeance, but instead demanding them, yet directing Athenians, as citizens, to show "moderation."

Accounting for the change in the Athena of The Eumenides to the Athena who drives her former ally and Greek hero, Ajax, to madness, then suicide, Kennedy points to the toll that war and imperialism have taken on Athenian democracy, ${ }^{67}$ where power, realpolitik, expediency and brutality-as seen clearly in Athens' attitude toward the Melians-have replaced the calls for justice popular only decades earlier. Ajax may have been represented in Athenian art as having fought side by side with Athena, but in the 420s, Kennedy writes, he represented "the Athens the Athenians pointed to in order to justify their power, but he was part of an Athens they could no longer claim to be," thus illustrating the discrepancy between ideology and reality. ${ }^{68}$ Kennedy points to the refusal of Athens to pay tribute to Persia, and associates Ajax, not only with this heroic past, but with the Melian attitude towards Athens in Thucydides' account, concluding that: "what was an absolutely unacceptable position to the Athenians in the 480s," here one should think of accepting to be subjected to an Empire, or

\footnotetext{
66 Ibid., 113-146.

67 Ibid., 126.

68 Ibid.
} 
abandoning Athenian pride, "had become their policy towards others a generation later."69 (emphasis mine) Demands of "moderation," made both by Athena to the people of Athens, and by the Athenians to the leaders of Melos, involve reverence and fear of a superior force, for the sake of the safety of those citizens of Melos and Athens. ${ }^{70}$

However powerful it may be to invoke The Eumenides in relation to the Nuremberg trial, it is striking to think how quickly-a matter of decades-the "bulwark of salvation across the empire" gave way, at least in the case of Athens, to the extermination of the men of Melos, and the enslavement of their women and children. It should give pause, too, to note the change in attitude towards the citizens of Athens themselves, once called to brave resistance, then after decades of hegemonic wars, cowed and invited to practice a "moderation" of fear..$^{71}$ As the Athena of The Eumenides can be said to appear anachronistically, like a Kant or Jackson figure, the Athena of Ajax seems ripped from the pages of Orwell. A relation may well exist between the exportation of democratic legal principles by a powerful state to other, less powerful allies, and the eventual distortion of that justice, both abroad and at home. Do the means of defense against foreign danger, to paraphrase James Madison, indeed "become the instruments of tyranny at home?”

\footnotetext{
69 Ibid., 138.

${ }^{0}$ Ibid., 139.

${ }^{71}$ See Judith Shklar, “The Liberalism of Fear," in Political Thought and Political Thinkers, Stanley Hoffmann, ed., (Chicago: University of Chicago Press, 1998); see, too, Corey Robin, Fear: The History of a Political Idea, (New York: Oxford University Press, 2004) 145-147.
} 


\section{Stung With Injury}

To "stay the hand of vengeance," as stated by the American prosecutor in Nuremberg, meant something like displacing those most likely justified urges, to as Aeschylus' furies had done, exact vengeance against the defeated Nazi leadership, and instead pay tribute to reason. This may have not been the simplest thing to achieve, and this is why Jackson suggests that it was praiseworthy to attempt justice through Western-style criminal trials, rather than by the extrajudicial assassinations (understandably) sought-at some point-by most of the allies. It is significant that American leadership sought and ultimately obtained these trials-which were revolutionary in that never before had individuals been subjects of international law-and that they were agreed to by nations having been much more than the U.S. "stung with injury." Injury is for instance what the American people experienced on September $11^{\text {th }}, 2001$, and it was then clear that recourse to courts was easier said than done. Could the hand of vengeance be stayed with respect to Osama Ben Laden, or, as we now know to be the case, were the furies of vengeance unleashed? Distinctions between the Nuremberg and Tokyo trials of defeated adversaries in what is called a conventional war (though certainly at the time, and for many conducting Shoah scholarship today, the actions of the Nazis were unprecedented, and thus hardly "conventional") can be offered in support of the different posture toward justice now demonstrated by the United States. The war against terrorism is a long-term proposition, and has not been definitively ended by a surrender of the type offered by the German leadership at the end of World War II. Justice, it is also 
argued, though appropriate for the murderers of millions in the judicial form, cannot conceivably be obtained in the case of Bin Laden. It is never offered that the crimes of the Nazis pale in comparison to the collective trauma provoked by the destruction of the twin towers of the World Trade Center, but it is, in contrast, assumed that security concerns and the very nature of the war against $\mathrm{Al}$ Qaeda (or ISIS today) precludes the possibility of anything vaguely resembling civilian justice. With Bin Laden's killing in May 2011, it seemed that the varied lessons that Judith Shklar's posthumously renovated concept of legalism, used as either a broad category designed to include approaches to international criminal law that favor judicial institutions ${ }^{72}$ (sometimes opposed to ad hoc courts),73 a commitment to due process inherent in liberal states (and to be contrasted with the approach of international relations realism), 74 or a mistaken view that international collective action problems can be solved through recourse to institutions that are unrealistic, ineffective, and ignore interests as well as their potential for rational attainment,75 no longer could hold sway. Other arguments in Shklar's Legalism, that have been construed to stand for the proposition that political trials are valuable to establish a historical record and prevent revisionist accounts, or the claim that to focus on due process and individual culpability is

\footnotetext{
72 Jack Snyder and Leslie Vinjamuri, " Trials and Errors : Principle and Pragmatism in Strategies of International Justice,” International Security 28 (3) (2003) 18-20, 13.

73 J.M. Czarnetzky, "An Empire of Law: Legalism and the International Criminal Court," The Notre Dame Law Review (2003) 79, 55.

74 Gary Jonathan Bass, Stay the Hand of Justice: The Politics of War Crimes Tribunals (Princeton: Princeton University Press, 2000).

75 Eric Posner, The Perils of Global Legalism, (Chicago, University of Chicago Press: 2009).
} 
"too narrow" in the context of international criminal law, ${ }^{76}$ as well as those that have purported to continue and expand on her work, offering a full-throated defense of liberal show trials, 77 seem, despite their post-cold war ubiquity, strangely silent for the purposes of judicial policy regarding the fate of one Osama Bin Laden, who was to be captured, as President George W. Bush put it, "dead or alive." It was President Bush's successor, President Barack Obama, who announced that bin Laden was dead, and that justice had thus been done, but did this justice resemble more that of the reviled nineteenth century lynch mobs than Robert Jackson's great mid-twentieth century oratory in favor of principles inherited from the eighteenth century enlightenment?

So Americans understand the costs of war. Yet as a country, we will never tolerate our security being threatened, nor stand idly by when our people have been killed. We will be relentless in defense of our citizens and our friends and allies. We will be true to the values that make us who we are. And on nights like this one, we can say to those families who have lost loved ones to al Qaeda's terror: Justice has been done. $7^{7}$

What are, precisely, "the values who make us who we are," and are they contingent upon events, and therefore depend on whether the nation has been flushed with victory, or stung with injury, or does it depend on degrees of victory and injury, and, if so, in what proportion? It is perhaps instructive to

\footnotetext{
76 Jenia Iontcheva Turner, "Defense Perspectives on Law and Politics in International Criminal Trials," 48 (3) Virginia Journal of International Law, 529-594, 535, 539.

77 Mark J. Osiel, "In Defense of Liberal Show Trials-Nuremberg and Beyond," in Perspectives on the Nuremberg Trial, Guénaël Mettraux, ed. (Oxford: Oxford University Press, 2008), 704. 78 "Remarks by the President on Osama Bin Laden," East Room, May 2 ${ }^{\text {nd }}, 2011$, http://www.whitehouse.gov/blog/2011/05/o2/osama-bin-laden-dead
} 
disambiguate practice and policy from principles when examining historical U.S. responses to security threats, as set out above, by President Obama.

Extraterritorial application of American policing or military actions to capture those who would violate the security, life, liberty, and property of U.S. citizens did not begin with the capture and killing of Bin Laden, nor did U.S. refusal to have its citizens subjected to "barbaric" foreign law wait for the American Servicemembers Protection Act (ASPA). ${ }^{79}$ Extraterritorial actions in the name of security, in instances that could be described as having properties of "exception" were features of the nineteenth century American legal landscape. The Ord Order, authorizing U.S. troops to enter Mexican territory as they saw fit to pursue "Indian raiders," was issued in $1877,{ }^{80}$ nine years before the capture, in Mexico, of the Apache Geronimo-whose name was attributed to Bin Laden in the very operation that resulted in his death-stands as a precedent for extraterritorial actions, deemed necessary in the name of either exceptionalism or exceptional national security claims of the United States, or both. ${ }^{81}$

Though the precedent for the kind of cross-border operation that resulted in the killing of Osama Bin Laden is more historically robust than the relatively recent U.S. commitment to favoring justice and the institution of a dispassionate

79 Daniel Margolies, Spaces of Law in American Foreign Relations: Extradition and Extraterritoriality in the Borderlands and Beyond, 1877-1898 (Athens, GA: University of Georgia Press, 2011), 9.

8o Id. Daniel Margolies, Spaces of Law in American Foreign Relations: Extradition and Extraterritoriality in the Borderlands and Beyond, 1877-1898 (Athens: University of Georgia Press, 2011), 9.

${ }^{81}$ Daniel Margolies formulates a strong argument that the choice of "Geronimo" to nickname Ben Laden in the raid that successfully took his life was no accident and is in fact consistent with exceptionalist American foreign policy since the late nineteenth century. "Geronimo, Ben Laden, and U.S. Foreign Policy,” George Mason University History News Network, http://hnn.us/node/139017\#disqus_thread 
trial to vengeance, the commitment to justice seems intimately connected to American self-perception as not only a law-abiding nation, but one whose values and practices regarding the respect for human rights radiate outward. Thus, the Bin Laden killing is not generally described as a deviation from a consistent U.S. commitment to justice, nor is it seen as an exceptional case of vengeance. Instead, discussions emphasize the justification for the killing, whether that justification is legal-as in the position defended, inter alia, by Harold Koh, former legal advisor to the State Department, that this killing was of a "high level belligerent" in the course of an armed conflict and was thus lawful pursuant to the laws of war-or justified morally, as with claims based on assumptions of just war theory, in the fashion of Michael Walzer. ${ }^{82}$ The first type of argument involves the determination of the type of law that applies to a given factual situation. If the laws of war, and not criminal law, apply to a specific individual (say Osama Ben Laden, but one might also say Anwar al-Awlaki, a U.S. citizen whose killing was authorized by President $\mathrm{Obama}^{83}$ ), then the interpretation of the situation regarding that individual militates against conducting a trial, but instead, and increasingly, as memos interpreting the law of war reportedly argue (though these interpretations have not been made fully public) authorize killing the individual.

\footnotetext{
82 These arguments (and others) are canvassed in Berkowitz, R. (10/2011). "Assassinating Justly: Reflections on Justice and Revenge in the Osama Bin Laden Killing". Law, culture and the humanities (1743-8721), 7 (3), p. 346.

83 Scott Shane, (April 6, 2010). "U.S. Approves Targeted Killing of American Cleric". The New York Times. Retrieved April 6, 2010.
} 
Just war theorists demand greater flexibility still: Walzer suggested, in his discussion of Ben Laden's killing 84 that though the positions taken on the question of whether the acts of September $11^{\text {th }}$ were to be viewed as a crime (and to be treated as such) or an act of war (and to be prosecuted accordingly) were normally considered mutually exclusive, "the truth is that each one is right, some of the time, in some places." Since Ben Laden was not captured in Paris, but rather in Abbottabad, where Walzer posits that conditions of peace do not exist, it is therefore justified to undertake an act of war, rather than the kind of trial that would be possible in a Western European capital. 85 "Killing Osama" writes Walzer, "did him no injustice," rather, the question is whether violence has been done to American principles by not trying him in a court of law. Walzer responds in the negative, arguing that it is neither just nor moral to require of commandos that they act like police officers when they are not in what he describes as a "zone of peace." Here, the just war position seems steeped in a military pragmatism that may well explain its contemporary cachet. Further, Walzer's recommendation that we might or ought to experience "gratitude that it was our Obama who did in Osama" sits quite uncomfortably with the passing concern that this action might have come into contradiction with a professed American preference-and for some, it is much more than a preference, and is in fact seen to be a quintessential feature of American political theory-for due process, and trials. Here, war, which Walzer has elsewhere claimed should be entered upon

\footnotetext{
84 Michael Walzer, "Killing Osama," Dissent, May $10^{\text {th }}$, 2011, http://www.dissentmagazine.org/online.php?id=484>. 85 Ibid.
} 
only with the greatest reluctance and trepidation, appears instead to be what Corey Robin has called "the great romance of the age, the proving ground of self and nation." 86 Moreover, the account of Ben Laden's killing as having been necessary in the face of armed resistance has been forcefully challenged by Seymour Hersh in a essay published in the London Review of Books. ${ }^{87}$ Although it generated substantial controversy at the time of its publication, the account offered by Hersh has at least tentatively been recently supported in the New York Times. 88

While the extrajudicial killing of Ben Laden by a nation stung with injury (“our Obama") was widely deemed justified, some were still unsettled by the total absence of legal-or rather judicial-participation in what they nonetheless consider to be a morally correct act. Roger Berkowitz confronts with apparent discomfort objections formulated by Kenneth Roth (executive director of Human Rights Watch) and Geoffrey Robertson that Ben Laden was killed rather than tried. Calling these types of objections "controversial," Berkowitz nonetheless gives consideration to Robertson's complaint that Ben Laden was not tried in The Hague by Muslim judges, and confronted to his crimes, resulting in not only a fair trial but a reduction of his stature, from a soulful figure on the mountain, to a shrill, screaming old man. For Berkowitz, the advantages set out by Robertson are mostly utilitarian, and pragmatic; what would stand for justice is a legal

86 Corey Robin, "Protocols of Machismo," London Review of Books, Vol. 27 No. 10, 19 May 2005. ${ }^{87}$ Seymour Hersh, "The Killing of Osama bin Laden," London Review of Books, Vol. 37 No. 10, 21 May 2015, 3-12.

88 Jonathan Mahler, "What Do We Really Know About Osama bin Laden's Death?," New York Times Magazine, October 15 ${ }^{\text {th }}$, 2015, <http://www.nytimes.com/2015/10/18/magazine/what-dowe-really-know-about-osama-bin-ladens-death.html?_r=0 $>$. 
judgment, "that Osama bin Laden was evil, a criminal, and that he deserved to be put to death." 89 This is far from seeming like the kind of thing that trials ever actually do, or ought to: basic premises of justice such as the presumption of innocence preclude a kind of spectacle meant to establish, in advance, that an individual is evil and that she (before a decision being made regarding her responsibility for the commission of an offence, and a determination of the appropriate legal punishment) deserved to be put to death. This is because Berkowitz is actually less interested in a trial of Ben Laden (whether in The Hague, in Guantanamo, or on an aircraft carrier, where Muslim judges, he offers with rather startling naiveté, would await him along with a crew of ready and competent defense lawyers prepared to try the case which could conclude in a matter of hours, and the proceedings be videotaped then released unedited) than he is in another kind of trial altogether.

Berkowitz proposes that the Navy SEALS who conducted Ben Laden's execution voluntarily put themselves on trial before an American jury to determine whether they acted justly. The jury would have to be American, as the SEALS would be entitled to the right to a fair trial-unavailable, Berkowitz presumes, in Pakistan-and the right to assert challenges to the jury, which presumably are unnecessary for Ben Laden, or indeed anyone brought before the International Criminal Court, or any ad hoc international tribunal where jury trials are unavailable. "The point is," writes Berkowitz, "only a jury - charged with the right to do justice - can offer the promise of a trial that might recognize

89 Roger Berkowitz, (10/2011). "Assassinating Justly: Reflections on Justice and Revenge in the Osama Bin Laden Killing". Law, Culture and the Humanities, 7 (3), 346, 349. 
and thus give legal cognizance to the justice of what the SEALS did." It is unclear whether Berkowitz grasps that jury trials are available for all persons accused of most classes of offenses in the United States, and not only those assumed innocent of murder because they killed an evil person.

The historical precedent for this kind of killing followed by legal imprimatur was first offered by Hannah Arendt, writing about the Eichmann trial, and later echoed by Samantha Power's opening paragraph in A Problem from Hell: America in an Age of Genocide. Sholom Schwartzbard and Soghomon Tehlirian were both tried for killing, respectively, Simon Petlura, the former Commander in Chief of the Ukrainian army during the pogroms in 1926 on the streets of Paris, and Talaat Bay in Berlin, in 1921. Both invoked at their trials that they killed great murderers, and both were acquitted (albeit for different reasons: Tehlirian was acquitted by reason of temporary insanity, not quite a ringing endorsement, at least from a legal standpoint, of the justness of his act). Berkowitz asserts, that "the point is that revenge, while itself an act outside of the realm of law and justice, can serve the interests of justice and promote justice when the avenger seeks and receives a judicial blessing for the act after the fact." 90 This means that justice ought to in fact be employed to prosecute only nominally those who kill, and in reality, used a mechanism for vengeancesetting the entire justification for Nuremberg, or even Athens' storied first criminal trial on its head-as the trial becomes a means of assessing the character

9o Ibid., 350 . 
of the assassin's victim, as Walzer argued ${ }^{91}$ rather than the crimes of the assassin herself. Walzer does not claim that the legal order, or the venue of the trial assesses the character of an assassin's victim. Rather, he claims that our common moral judgments might favorably view the assassination of a Hitler-like person. Walzer correctly, here, distinguishes between the legal and moral orders.

The trial venue as espoused by Berkowitz offers the possibility of some kind of spectacle where it is the victim who is judged-very much in absentiarather than the killer. Here the trappings of justice are on display, satisfying a sort of desire for a judicial form, but only for the process to deprive that real accused - the person deemed worthy of killing—of the rights that make trials something we can legitimately describe as representing a tribute that power would pay to reason.

If the ex-post facto legal approach seems familiar, it is because it has also been defended in the context of torture, by those who like Jean Bethke Elshtain, Henry Shue, Sanford Levinson, (as well as Alan Dershowitz and Michael Walzer, albeit in different ways) ${ }^{92}$ would not like torture to be subject to legal prohibitions, but for the practitioner of torture to be given an opportunity to establish a judicial justification for her action. This line of argument borrows from the theory of civil disobedience, where one submits to justice acknowledging that one has broken the law, but has done so for a higher good or in order to

\footnotetext{
${ }^{91}$ Just and Unjust Wars, $4^{\text {th }}$ edition, 199-200.

92 Torture: A Collection, ed. Sanford Levinson, (Oxford: Oxford University Press, 2004), see Corey Robin's review and discussion, "Protocols of Machismo," London Review of Books, Vol. 27 No. 10, 19 May 2005.
} 
publicize a neglected political demand. That torture is the object of an absolute, unqualified prohibition in international law has not tempered the ardor of those who argue those restrictions ought to be relaxed in the current circumstances of insecurity and to prevent terrorist attacks. 93 Critiques of such "legalization" arguments, going beyond the simple restatement that torture is quite obviously illegal, have revolved around four main objections: that torture is not effective, that torture is cruel (not seeking out information, but silencing the subject), that the "ticking time-bomb" scenario though perhaps on occasion justified, can quickly slip into routinized torture, and finally, that even if torture is committed, it must remain illegal, and the torturer must know that the act is not only wrong, but violates the law. 94 This deviation from international law is a more general phenomenon, and may paradoxically constitute an inherent characteristic of states' attempts to govern the international order through legal norms.

Power and Law: Pessimism of the Intellect, Optimism of the Will

At the heart of international law lies a fundamental duality regarding authority: there are texts, "positive law"-treaties, General Assembly resolutions, as well as judicial opinions; then, there is state practice. "International law," writes Paul W. Kahn, "advances-or retreats-along both dimensions at once.95”

\footnotetext{
93 Susan Marks and Andrew Clapham, International Human Rights Lexicon, 1 edition (Oxford University Press, 2005). 376-380

94 Ibid.

95 Paul Kahn, "From Nuremberg to the Hague: The United States Position in Nicaragua v. United States and the Development of International Law," Faculty Scholarship Series, January 1, 1987, http://digitalcommons.law.yale.edu/fss_papers/339., 3
} 
In short, "deviant practice"-that is the exercise of among other things, but most importantly, power-has the potential to create law. Power, then, for better or worse, because it is permitted, by legal definition, to shape law, is, though distinguishable from it, inextricably bound up within it. This internally contradictory incorporation of power into international law has historically been a source of confusion, frustration and distress, and has thus too frequently been shielded from view.

It is perhaps a fool's errand to attempt an original definition of power. Even Hans J. Morgenthau's great Scientific Man and Power Politics only introduces the term that figures prominently in the book's title at page 195 (out of 223 pages). ${ }^{6}$ It is nonetheless essential to offer a sense of what could be meant by it in assessing power's relation to the law. In Morgenthau's later and vastly influential Politics Among Nations, he devoted an early chapter to the concept, setting out clearly what he meant by power and its centrality in both domestic and international politics. ${ }^{97}$ Power, for Morgenthau, is first man's control over the actions and minds of other men, while political power refers to a relation between holders of public authority, as well as between the latter and the people at large. ${ }^{8}$ Strongly influenced by Max Weber, ${ }^{99}$ Morgenthau's conception of power is first an influence over minds-thus acknowledging the autonomy of the

\footnotetext{
${ }_{96}^{6}$ Hans Joachim Morgenthau, Scientific Man vs. Power Politics (University of Chicago Press, 1967).

97 Hans Joachim Morgenthau and Kenneth W. Thompson, Politics among Nations: The Struggle for Power and Peace (Knopf, 1985).

98 Ibid., 32.

99 Martti Koskenniemi, The Gentle Civilizer of Nations: The Rise and Fall of International Law 1870-196o (Cambridge University Press, 2004) 447-448; Michael C. Williams, "Why Ideas Matter in International Relations: Hans Morgenthau, Classical Realism, and the Moral Construction of Power Politics," International Organization 58, no. 4 (October 1, 2004): 633-65, 637.
} 
person in relation to whom it is exercised-deriving from three sources: "the expectation of benefits, the fear of disadvantages, the respect or love for men or institutions." 100 Michael Williams has aptly observed, arguing against the wellworn claim the Morgenthau's conception of power is too simplistic to be of any use in today's international relations scholarship, that Morgenthau deploys the sophisticated strategy of indeterminacy in presenting power as an open sociological concept. ${ }^{101}$ Power's "content and the matter of its use are determined by the political and cultural environment," writes Morgenthau, and "may comprise anything that establishes and maintains the control of man over man." Power, for Morgenthau, is not only sensitive to cultural and political context, but covers all social relationships from physical violence to psychological control; it can be moral, when controlled by constitutional safeguards, or be a "barbaric force which finds its laws in nothing but its own strength and its sole justification in its aggrandizement." ${ }^{102}$ Further distinctions are offered between influence and power (persuasion as opposed to compulsion); power and force (the use of force as an abdication of political power); usable and unusable force (that is the threat as opposed to the use of nuclear weapons); and finally the distinction between legitimate and illegitimate power (a morally or legally legitimate power, as opposed to naked power). ${ }^{103}$

Morgenthau's conception of power is both sufficiently indeterminate and precise to explore it in relation to law, and more specifically international law. In

\footnotetext{
${ }^{100}$ Morgenthau and Thompson, Politics among Nations, 32. ${ }^{101}$ Williams, "Why Ideas Matter in International Relations," 638. 102 Morgenthau and Thompson, Politics among Nations, 11. 103 Ibid, 33-34.
} 
theory-recent Supreme Court judgments notwithstanding-the transition from politics to law can be understood as a shift from power (a potentially asymmetrical relation) to equality. Domestically, law supposes equality between individual citizens and internationally, between sovereign states. ${ }^{104}$ Once rules are set, in this conception, outcomes of a dispute should not depend on the relative power of the parties, but on the qualification of facts and the interpretation of rules. This explains, writes Kahn in an article published after the end of the cold war but before the events of September 11th, 2001, why weaker nations have had recourse to international majoritarian institutions not controlled by great powers-like the International Court of Justice-and conversely why most great powers prefer to avoid those same institutions, citing that among the five veto holding members of the United Nations Security Council only Great Britain recognizes the compulsory jurisdiction of the ICJ. ${ }^{105}$ Since the ratification of the International Criminal Court, of the same veto holding members of the Security Council, only France and Great Britain have become member states of the ICC. Moreover, the international order provides a diminished range of adjudicatory and enforcement mechanisms in comparison to domestic institutional arrangements, and thus internationally, power, understood here as the possibility of advancing state interests independently of norms and procedures, weighs significantly more than law. ${ }^{106}$

\footnotetext{
104 Paul Kahn, "Speaking Law to Power: Popular Sovereignty, Human Rights, and the New International Order," Faculty Scholarship Series, January 1, 2000, http://digitalcommons.law.yale.edu/fss_papers/329, 1. 105 Ibid. ${ }^{106}$ Ibid., 2.
} 
It is on the question of the influence of the practice of sovereign states on the evolution of international law that the disproportionate weight of power and the weakness of law's normative sway is the most evident. The history of the use of force in international conflicts provides the sharpest examples of a deviant evolution of international law, through the use of power, which when employed as force, as defined by Morgenthau above, has abdicated the practice of politics.

In addressing the issue of judicial settlement of disputes, Morgenthau astutely diagnosed the central problem at the intersection of international adjudication and war: casus belli were never, he claimed, a question of interpretation of the law as it stood, but rather political demands to modify the legal status quo. Everyone knew the legal status of Czechoslovakia in 1938, observed Morgenthau, and thus the issue was not then-nor in other controversies since-about the interpretation of existing law, but rather a challenge to its legitimacy and a demand to change it. ${ }^{107} \mathrm{He}$ then distinguished "status quo nations," in whose interest it was to have recourse to courts, whose authority, as Judith Shklar also notes, rests on that very status quo, ${ }^{108}$ and "imperialistic nations" who are "inevitably opposed to the existing status quo and its legal order."109 For a more recent example of this insight we might observe how the defense of humanity, rather than stated imperialist aims, was the justification for the demand to change international norms in NATO's decision to bomb Yugoslavia in 1999, described by the Chinese ambassador as a severe

\footnotetext{
107 Morgenthau and Thompson, Politics among Nations, 464. 108 Judith Shklar, Legalism: Law, Morals, and Political Trials (Harvard University Press, 1964), 135 .

109 Morgenthau and Thompson, Politics among Nations, 465.
} 
violation of international law. ${ }^{110}$ Shklar, too, paid attention to the question of the status quo, but highlighted the other side of the coin: she argued that one of the weaknesses of the Tokyo trials was that it provided an opportunity to Indian judge Radhabinod Pal to expose American designs in Asia. The crime of aggressive war, construed by the Americans to mean a challenge to the status quo, "could and did appear as nothing but an ideological defense of colonialism." ${ }^{111}$ For Shklar, the challenge of the status quo was made unavailable not for the imperialists, but for those peoples suffering colonial rule, the very victims of the imperialism Morgenthau, once in the U.S., saw as the main and inevitable challenger to the status quo. But Morgenthau, as William Scheuerman explains, had already in 1929 when still in Germany and working with leftist labor lawyer Hugo Sinzheimer formulated an argument strikingly similar to Shklar's and to Pal's: that the static nature of international law did not take into account political and social change, putting weaker states in the position of having "to abide for all eternity to norms privileging the great powers." 112

War, or the use of power through force, can change the law. So, too, can ex-post facto legal institutions attempt to assess whether such recourse was lawful. The first historical precedent was the Nuremberg Trial of the German Major War Criminals in 1945 to 1946, about which Prosecutor Robert Jackson, in his opening statement, said that it was part of an effort "to make the peace more

${ }^{110}$ Mark Mazower, Governing the World: The History of an Idea (Penguin Press HC, The, 2012), 387.

${ }^{111}$ Shklar, Legalism, 180.

112 William E. Scheuerman, "Realism and the Left: The Case of Hans J. Morgenthau," Review of International Studies 34, no. 01 (2008): 29-51, 39. 
secure." ${ }^{113}$ Nuremberg could only claim to determine the legality of Nazi actions because the trial was established by the victors of the war; moreover, its significance was in trying individuals as defendants pursuant to criminal law. At issue was the status under international law of state violence, and Kahn formulates the intriguing claim that "if state violence were not justiciable, then neither would individual responsibility for that violence be justiciable. ${ }^{114}$ Justiciability, then, of violence (the more naked type of power) was to be viewed as analogous to self-defense in domestic law: a justification of the use of violence that could only be confirmed or dismissed institutionally after a criminal trial. Some defense lawyers, in particular General Alfred Jödl's counsel, scholar and lawyer Hermann Jahrreis, saw matters differently, and argued that in light of the numerous reservations contained in the Kellogg-Briand Pact, the treaty upon which the prosecution primarily relied for the crimes against the peace counts, "Only on one thing did complete agreement exist: War of self-defense is permitted as an inalienable right of all States; without this right, sovereignty does not exist; and every state is judge of whether in a given case it is waging war of self-defense."115 Jahrreis' argument was ultimately unsuccessful; the tribunal held that the right of states to self-defense did not preclude the court's ability to judicially determine whether illegitimate actions such as aggression had taken place.

113 International Military Tribunal, Trial of the major war criminals before the International Military Tribunal, Nuremberg, 14 November 1945-1 October 1946. (Nuremberg, Germany: [s.n.], 1947), 85 .

114 Paul Kahn, "From Nuremberg to The Hague: The United States Position in Nicaragua $v$. United States and the Development of International Law," Faculty Scholarship Series, January 1, 1987, http://digitalcommons.law.yale.edu/fss_papers/339, 6. 
Kahn's account of the Nuremberg episode is designed to shed light on another, more recent, legal argument formulated by the United States before the ICJ in The Hague in the suit brought against it by Nicaragua for military and paramilitary activities on its territory. The U.S. opposed the jurisdiction of the ICJ arguing that it was acting in self-defense (of its Salvadoran ally), but more crucially that the ICJ is not competent to make determinations regarding the legality of the use of force, a jurisdiction reserved exclusively to the United Nations Security Council.116 The U.S. position amounted to the failed Nuremberg argument that stood for the proposition that the determination of self-defense is non-judiciable, that, in other words, (Security Council) power trumps law. This has also been the U.S. position regarding the hypothetical crime of aggression finally defined by the state parties of the ICC.117 It now seems that perhaps Nuremberg did not stand for the rule, but rather for the exception, at least where the five veto-holding members of the Security Council are concerned.

The phenomenon of human rights, streamlined to stand for those most extreme violations by the state against its citizens, or simply put, atrocities, ${ }^{118}$ emerged with force at the end of the cold war. The idea of human rights-though the argument had been used before, and including as a subsidiary claim by the US in the Nicaragua case ${ }^{119}$-is one of the crucial ways in which international law

\footnotetext{
116 Ibid., 12.

117 Carrie McDougall, The Crime of Aggression Under the Rome Statute of the International Criminal Court (Cambridge University Press, 2013), 10; Sean D. Murphy, United States Practice in International Law: 1999-2001 (Cambridge University Press, 2002), 386. ${ }^{118}$ Samuel Moyn, The Last Utopia: Human Rights in History, Reprint (Belknap Press, 2012), 226.

119 Kahn, "From Nuremberg to the Hague," January 1, 1987, 45.
} 
sought to reinvent itself after the end of the cold war. ${ }^{120}$ Kahn saw early on that the rise of human rights in the context of American hegemony, especially in light of its sovereign self-understanding as a nation of law and rights from within, not to be subjected to law and rights from without-might appear to others in the world as a Western project, a kind of cultural imperialism. ${ }^{121}$ After a few years, years that have seen wars and failure of post-cold war's promises to deliver the dividends of prosperity and peace, Kahn's concern is reflected in a growing critique of the idea of human rights as a via media between power and law. At times, they have stood for both. The all-powerful human rights discourse has left unresolved conflicts aside and tolerated that victims of less-extreme injustice forego demands for more tangible kinds of reparations and the redistribution of wealth. ${ }^{122}$ The discourse has shifted from a revolutionary, vulnerable call for law's equality to an established mode of governance and an exercise of power. ${ }^{123}$ The project of rights-based international law, such as the one articulated by AnneMarie Slaughter, ${ }^{124}$ "mandating" distinctions between different types of states, is familiar to historians of nineteenth century international law and its insistence on the difference between civilized and non-civilized states. ${ }^{125}$ To Slaughter's credit, she predicted that very response and identification, but concluded that

\footnotetext{
120 Frédéric Mégret, in José María Beneyto and David Kennedy, New Approaches to International Law: The European and the American Experiences (Springer, 2013), 4.

${ }^{121}$ Kahn, "Speaking Law to Power," 18.

122 Robert Meister, After Evil: A Politics of Human Rights (New York: Columbia University Press, 2012), 38.

123 Mégret in Beneyto and Kennedy, New Approaches to International Law, 6; Moyn, The Last Utopia, 227.

124 Anne-Marie Slaughter, "International Law in a World of Liberal States," European Journal of International Law 6, no. 1 (January 1, 1995): 503-38, 504.

125 Antony Anghie, Imperialism, Sovereignty, and the Making of International Law (Cambridge, UK; New York: Cambridge University Press, 2007), 296; Mazower, Governing the World, 72-74.
} 
"whether a liberal/non-liberal distinction is used or abused for similar purposes depends on the normative system developed to govern a world of liberal and nonliberal States." ${ }^{126}$ Two decades have passed and it is fair to state that the nascent critique of international human rights law is precisely based on the failure of the "normative system developed to govern the world" to deliver both the goods and the good.

Slaughter-type endeavors are critiqued as not only necessarily advancing an imperial agenda-not as a result of bad faith or conspiracy, as Koskenniemi puts it-but because the logic of the argument points to morality rather than to law, or rather hopes to salvage the law by making it an instrument of the values of the powerful. ${ }^{127}$ Moreover, the focus on instrumentalism "silently assumes that the political question-what the objectives are-has already been resolved." ${ }^{128}$ So, too, has the human rights discourse, in its successful attempt to transcend politics ended up with a very minimal content, and has been "bound up in the power of the powerful."129

A related problem concerns the morality of jurisdiction. The International Criminal Tribunal for the Former Yugoslavia and the International Criminal Tribunal for Rwanda were established by the Security Council of the UN; subsequent bodies were created by hybrid means; finally, the International Criminal Court is a treaty-based body. These differences in organization are fairly

\footnotetext{
${ }^{126}$ Slaughter, "International Law in a World of Liberal States," 506.

127 Koskenniemi, The Gentle Civilizer of Nations, 484.

128 Ibid., 485.

129 Moyn, The Last Utopia, 227.
} 
uncontroversial, as is the notion that once a legal (or law-like) body is created, it will neutrally adjudicate claims pursuant to its jurisdiction. This view is challenged by Kenneth Anderson who has made the striking claim that the conventional legal view is morally wrong, and that instead, "the right to judge is the rights one earns. ${ }^{130}$ The right is earned, offers Anderson, by a willingness to intervene-and therein lies the connection to the current human rights discourse-rather than to adopt what he calls "a stance of passive, perhaps handwringing neutrality." Conceding that justice is universal, he opposes justice (and it is unclear whether the notion relates to power or to law) to the right to administer it, the latter belonging to "the just party or the party of the just party." 131 This is the same just war theory relied upon by President Obama in his speech about the use of drones, ${ }^{132}$ a practice that as far as is known has killed 3000, including 800 civilians and at least four American citizens ${ }^{133}$ and for at least those reasons, and probably others, it deserves close scrutiny.

Judith Shklar described her friend Michael Walzer's just war theory as one that places war on one end of a continuum that has "the harmonious consensual

\footnotetext{
${ }^{130}$ Kenneth Anderson, "The Rise of International Criminal Law: Intended and Unintended Consequences,” European Journal of International Law 20, no. 2 (April 1, 2009): 331-58, 338. ${ }^{131}$ Ibid. 132 “Obama’s Speech on Drone Policy,” The New York Times, May 23, 2013, sec. U.S. / Politics, http://www.nytimes.com/2013/05/24/us/politics/transcript-of-obamas-speech-on-dronepolicy.html.

133 "Killer Drones: How America Goes to War in Secret by Michael Hastings | Politics News | Rolling Stone," Rollingstone.com, accessed June 26, 2013, http://www.rollingstone.com/politics/news/the-rise-of-the-killer-drones-how-america-goes-towar-in-secret-20120416; "Get the Data: Drone Wars Archives," The Bureau of Investigative Journalism, accessed December 6, 2015, https://www.thebureauinvestigates.com/category/projects/drones/drones-graphs/.
} 
community" on the other. ${ }^{134}$ War for just war theorists, is, as the name implies, not outside the rules of law and morality, in contrast to the Kantian view that war is beyond the rules of good and evil, an absolutely prohibited practice, never justified, falling only into the realm of necessity and self-preservation. ${ }^{135}$ The Kantian view, in Shklar's assessment, is to hold that just war theorists encourage people to recklessly enter into wars "and then baptizing his own side with the holy water of justice." "Every enemy," she writes, "can be made to look the aggressor." ${ }^{36}$ Anderson's "earned right to judge" by having intervened as the just party poses a greater problem still: in addition to it being possible to "baptize one's own side," it is possible to think of very few states who would, in addition to being convinced that they are just-which is sadly not a difficult thing at allpossess the military and political power required to earn the "right" to judge, ex post facto, with the determination of justice already pronounced.

Are drones to be best understood by a theory of just war? Looking at the targets, Paul W. Kahn has recently published a chilling argument: they are not criminals to be tried with the protections of law, nor innocent military personnel engaged in warfare. ${ }^{137}$ It is, he argues, the status of the target that illuminates the nature of the enterprise. It is neither war nor is it the application of the law; the classical distinction between criminal and enemy has dissolved. Drone strikes, instead, diagnoses Kahn, are statecraft as the administration of death; a high-

\footnotetext{
134 Judith N. Shklar, Ordinary Vices (Belknap Press of Harvard University Press, 1985), 80. 135 Ibid.; Immanuel Kant, Kant: Political Writings, ed. H. S. Reiss, trans. H. B. Nisbet, 2nd ed. (Cambridge University Press, 1991), 103. ${ }^{136}$ Shklar, Ordinary Vices. ${ }_{137}$ P. W. Kahn, “Imagining Warfare," European Journal of International Law 24, no. 1 (April 7, 2013): 199-226.
} 
tech form of a regime of disappearance. For Kahn, the use of drones in the war on terror cannot be understood by reading Clausewitz or Kant, but by following Machiavelli. ${ }^{138}$ French philosopher Grégoire Chamayou, who like Kahn shares the concern that the use of drones to kill lies uncomfortably somewhere between warfare and policing, theorizes the drone's function as that of nothing short of a manhunt, ${ }^{139}$ or more starkly, as Philip Alston has put it, "a license to kill." 140 Proponents of drone strikes such as Kenneth Anderson have expressed concern that the lack of firm legal guidance for the use of these unmanned aerial vehicles might compromise their future use, and thus Anderson proposes a new regime of ad hoc law he would call "naked self-defense." 141 This is understood by Chamayou to mean that it would automatically invoke self-defense without respecting the legal restrictions that generally confine the justification. We have seen the troubled precedents for the invocation of self-defense absent a judicial determination-both in Nuremberg and before the ICJ in the Nicaragua casebut Anderson's drone exception goes further still: "self defense gives the discretionary ability to attack anywhere in the world where a target is located, without having to make claims about a state of armed conflict everywhere and always across the world." ${ }^{142}$ How would such a rationale square with Kant's prohibition of assassins and assassinations in Article 6 of the Preliminary Articles

\footnotetext{
${ }^{138}$ Ibid., 216.

139 Grégoire Chamayou, A Theory of the Drone (New York: The New Press, 2015), 172.

140 Philip Alston, Report of the Special Rapporteur on Extrajudicial, Summary or Arbritrary Executions, Addendum, Study on Targeted Killings, UNO, May 28, 2010, 3, in Chamayou, 173. ${ }_{141}$ "More Predator Drone Debate, in the Wall Street Journal, and What the Obama Administration Should Do as a Public Legal Position - The Volokh Conspiracy," accessed December 6, 2015, http://volokh.com/2010/01/o9/more-predator-drone-debate-in-the-wallstreet-journal-and-what-the-obama-administration-should-do-as-a-public-legal-position/, in Chamayou 172-173.

142 Ibid.
} 
for Perpetual Peace Among States?

Beyond a theoretical exploration of continued state practice deviating from black letter international (and perhaps domestic) law, it is worth stopping briefly to assess the efforts of American drone victims' families to quite legalistically seize the institutions of American courts to either prevent strikes (in favor of a traditional criminal resolution) or to receive clarity about the death of an innocent 16 year-old. Such were the efforts of Nasser Al Awlaki, who after earning his Ph.D. in the United States as a Fulbright Scholar, went on to become Yemen's Minister of Agriculture and President of Sana'a University. His son, Anwar, and grandson, 16 year-old Abdulrahman, were both born in the United States, were U.S. citizens, and were killed by U.S. drone strikes two weeks apart. Dr. Al-Awlaki joined the ACLU and the Center for Constitutional Rights in a lawsuit questioning the propriety of his son Anwar's inclusion on a "kill list," arguing inter alia that the imminent harm justification for targeted killing is not met when names remain on that list for months at a time, and that the U.S. Constitution requires a transparent account of the legal criteria upon which inclusion of the kill list is determined for any specific individual. ${ }^{143} \mathrm{~A}$ federal court dismissed the case on December $7^{\text {th }}, 2010 .{ }^{144}$ President Obama announced that Anwar Al-Awlaki had been killed by a drone strike on September $30^{\text {th }}$,

\footnotetext{
143 "Al-Aulaqi v. Obama - Constitutional Challenge to Proposed Killing of U.S. Citizen," American Civil Liberties Union, accessed December 6, 2015, https://www.aclu.org/cases/al-aulaqi-vobama-constitutional-challenge-proposed-killing-us-citizen. 144 Ibid.
} 
2011. ${ }^{145}$ The following year, the ACLU and CCR filed a new lawsuit arguing that Abdulrahman Al-Awlaki, son and grandson of Anwar and Nasser Al-Awlaki had been killed without due process. The case was dismissed on national security grounds. ${ }^{146}$ Dr. Al-Awlaki, who had fervent faith in the ability of the U.S. courts to deliver justice for his grandson, decided not to appeal the ruling. "I have no faith left in a judiciary that refuses even to hear whether Abdulrahman, an American child, was wrongfully killed by his own government," he stated, adding "although the court failed to fulfill its role in this case, my family and I continue to hope that answers to our questions about why our son and grandson were killed will someday see the light of day, and that there may someday be accountability for the government's actions." 147

Abdulrahman's death certificate was accompanied by a standard State Department form entitled "Death of an American Citizen Abroad”; it falsely recorded his cause of death as "unknown." 148 Subsequently, an unnamed U.S. official told the Washington Post that the teenager had been "in the wrong place at the wrong time" when he, along with another U.S. citizen, were killed by a Predator drone in Yemen. ${ }^{149}$ In 2012, the New York Times took pains to show the

\footnotetext{
145 Scott Shane, “The Lessons of Anwar Al-Awlaki,” The New York Times, August 27, 2015, http://www.nytimes.com/2015/o8/30/magazine/the-lessons-of-anwar-al-awlaki.html. 146 "Relative of Americans Killed by Drone Strikes: No Justice in U.S. Courts," American Civil Liberties Union, accessed December 6, 2015, <https://www.aclu.org/blog/relative-americanskilled-drone-strikes-no-justice-us-courts $>$.

147 Ibid.

148 "The Anwar Al-Awlaki File," accessed December 6, 2015, http://nsarchive.gwu.edu/NSAEBB/NSAEBB529-Anwar-al-Awlaki-File/. 149 "U.S. Airstrike That Killed American Teen in Yemen Raises Legal, Ethical Questions - The Washington Post," accessed December 6, 2015, <https://www.washingtonpost.com/world/national-security/us-airstrike-that-killed-americanteen-in-yemen-raises-legal-ethical-questions/2011/10/20/gIQAdvUY7L_story.html>.
} 
difficult process of decision-making as it relates to the "kill list," portraying President Obama as carefully and thoughtfully weighing national security imperatives against the respect for the Constitution, and indeed morality. ${ }^{150} \mathrm{He}$ is described as a student of Aquinas and St. Augustine ${ }^{151}$ - perhaps he even consults Michael Walzer's Just and Unjust Wars. Obama has not spoken about the killing of Abdulrahman Al-Awlaki, but his 2012 campaign spokesperson, Robert Gibbs, when pressed on the question of lack of due process, the absence of trial, and the fact that Al-Awlaki was a minor when he was killed by the U.S., said "I guess I would suggest that you should have a far more responsible father if they are truly concerned about the well-being of their children." ${ }^{52}$ It is not difficult to understand how Dr. Al-Awlaki lost faith in American legal institutions, but one could be forgiven, too, for understanding it if he lost his faith in U.S. politics.

International law is deeply, perhaps irremediably-short of Kant's Perpetual Peace in a federation of free states ${ }^{153}-$ steeped in power. Between the two, and even within the waning empire of human rights, ${ }^{154}$ lies not a new utopia, but perhaps the old, plain business of an unself-conscious politics of contestation and of aspiration. This brings us to American liberalism.

\footnotetext{
${ }^{150}$ Jo Becker and Scott Shane, "Secret 'Kill List' Tests Obama's Principles," The New York Times, May 29, 2012, http://www.nytimes.com/2012/05/29/world/obamas-leadership-in-war-on-alqaeda.html.

151 Ibid.

152 "How Team Obama Justifies the Killing of a 16-Year-Old American - The Atlantic," accessed December 6, 2015, http://www.theatlantic.com/politics/archive/2012/10/how-team-obamajustifies-the-killing-of-a-16-year-old-american/264028/.

153 Kant, Kant, 102.

154 Kahn, “Imagining Warfare,” April 7, 2013, 226.
} 
We, the People and the World: American Liberalism's Troubled Relationship with International Law

One is hard pressed to find an account of liberalism-be it by its proponents or by its critics-that does not feature the rule of law as one of its main tenets, if not as its central normative feature. ${ }^{155}$ And whether this rule of law emerges as a moral duty to pull unfortunate members of a territorially-defined group out of a state of nature and into a civil society on the basis of autonomy and freedom, as in the Kantian account defended by Anna Stilz; as an administrative process yet to be tamed by reasoned democratic deliberative reasoning, as with Henry S. Richardson; as the fetichized locus of a political-theological project, as presented in the manner of a foundational myth by Paul Kahn; or alternately, as a symptom of political sovereignty's shift from boundedness to aggrandizement through will, as is Jean Bethke Elstain's contention; to finally, a necessary evil, to be viewed with some democratic wariness and a good dose of pluralist skepticism, as with Michael Walzer, the law is, however variable, nonetheless always important. In fact, it is critical.

As difficult as it is to secure agreement as to the ontological nature and epistemic requirements of law on a liberal view, the challenges that confront the liberal idea of law increase exponentially when considered as an international phenomenon. It is not a coincidence that Judith Shklar chose to write her 1964

\footnotetext{
155 Judith N. Shklar, Legalism, (Cambridge: Harvard University Press, 1964); Anna Stilz, Liberal Loyalty, (Princeton: Princeton University Press, 2009); Henry S. Richardson, Democratic Autonomy: Public Reasoning About the Ends of Policy, (Oxford: Oxford University Press, 2002); Bethke Jean Elshtain, Sovereignty: God, State and Self (New York: Basic Books, 2008); Paul W. Kahn, Putting Liberalism in its Place, (Princeton: Princeton University Press, 2005); Michael Walzer, Thinking Politically, (New Haven: Yale University Press, 2007).
} 
Legalism about the Nuremberg and Tokyo trials. It is when justice is conceived of beyond the territorial borders of the modern sovereign state that problems emerge with the greatest acuity for liberals. This is because-as Anna Stilz would know, though it is not something that she clearly lets on-Kant's assessment, in Perpetual Peace, of international relations existing as a state of nature has yet to change, all moral claims of rights to humanitarian intervention ${ }^{156}$ to the contrary notwithstanding. ${ }^{157}$ Kant is still not far from wrong today when he wrote that states have "no external tribunal to put their claims to trial," 158 as indeed courts, which by nature must possess the capacity to enforce their own decisions, do not currently exist-with such an enforcement power- between states at the international level. ${ }^{159}$ Judicial bodies have, however, been created by the United Nations Security Council as well as by the Rome Treaty, and these courts-or "law-like political institutions," and Judith Shklar would put it, ${ }^{160}$ have jurisdiction over individuals. The difficulty is that they have (absolute) jurisdiction only over individuals of those nations who are not permanent members of the Security Council, and who cannot themselves create ad hoc

\footnotetext{
${ }_{156}$ Walzer, Thinking Politically.

${ }_{157}$ Immanuel Kant, Perpetual Peace, in Kant's Political Writings (ed. Hans Reiss), (Cambridge: Cambridge University Press, 1970)

103-104.

158 Ibid., 104

159 "Under Article 36 of the Statute of the ICJ, the court does not have jurisdiction over a dispute without the consent of the state parties involved in the dispute. See Monetary Gold Removed from Rome in 1943 (Italy v. Fr.), 1954 I.C.J. 19 (June 15). When the ICJ has been aggressive in construing consent, states, including the United States, have simply refused to participate further in the merits stage of the case. See Jonathan I. Charney, Disputes Implicating the Institutional Credibility of the Court: Problems of Non-Appearance, Non-Participation, and NonPerformance, in The International Court Of Justice At A Crossroads 288 (Lori Fisher Damrosch ed., 1987)." See Paul W. Kahn, "War Powers and the Millennium," Loyola of Los Angeles Law Review, 34 (11) 11-60, 35. 160 Shklar, Legalism, 156.
} 
bodies, or who do not-more importantly-have the power to refuse to submit to the jurisdiction of a tribunal such as the International Criminal Court, by for instance, deciding to exercise their power of veto to prevent the referral of an investigation of their own nationals.

Several issues are thus apparent, and require some explanation and justification by liberals. International justice-or perhaps more accurately, international law-when set out in such a stark manner, may appear illiberal in many ways. First, inconsistent application of the law can appear to do violence to principles of equality and fairness. The lack of universality in the application of the repressive mechanisms of international criminal law suggests that the process may be arbitrary, depending, for its implementation, on inconsistent circumstances, and more troublingly, is sensitive to power (to an unacceptable degree) and thus violates deeply held liberal commitments to the principle of equality. Secondly, the extent to which politics (in this instance, international politics) play a role in the determination of situations that require adjudication (or intervention) seem removed from the type of rationally-based procedural mechanisms liberals are committed to when issues are determined in a legal or judicial manner.

Finally, power wields a far greater influence in the determination of what (or who) will or will not be scrutinized by international "law-like political institutions" than what liberals are generally comfortable with. This last point coexists with liberalism's occasionally uneasy view of sovereignty, as this idea is what, at least for some powers internationally, permits and justifies immunity 
from prosecution; it is also the same concept that is (often by the same states who invoke it for the protection of their own interests) viewed as a platitudinous orthodoxy of a bygone era-or at least as something that in extreme cases, plays a counterproductive, if not frankly dangerous role in the international post-cold war environment.

A corollary to these questions has to do with the kinds of wrongs that justify international legal action, and specifically whether there exists any (liberal) basis to state that individuals can claim a right to be protected against such wrongs, or, of greater relevance here, of a right (or perhaps duty) for states or other arrangements to intervene on behalf of such individuals when they are citizens of foreign states, on foreign soil, and thus subject to the law of another jurisdiction. ${ }^{161}$ Then, brutally put, are we prepared to kill to fulfill this purpose, and to sacrifice our own lives?162

Liberals will also take an interest in the manner in which international rights, duties, procedures and institutions come into existence; liberal commitments afford some importance to the nature of agreements that generate obligations, create law (whether it is genuinely enforceable or not), and in extreme cases, the ability to deprive individuals of liberty-such as in the context of an ad hoc or permanent criminal or war crimes prosecution-or to engage in war, which frequently extinguishes the lives of individuals, whether they be compatriots or people living in other states.

${ }^{161}$ Walzer, Thinking Politically, 255.

162 Ibid., 256 


\section{Sovereignty}

It is perhaps tempting to make sovereignty out as the villain in this state of affairs, that which prevents claims of right from fully and fairly being adjudicated equally, against all, or even as the very cause of intemperate war and massive crimes committed by states. Before examining what sovereignty is responsible for, however, it is worth attempting to explore what it is (and in relation to what). This is of course a very difficult question, and efforts to define sovereignty may vary in clarity and quality across theorists and depend on their own ontological and political commitments. Paul Kahn defends what he presents as a distinctly American view, ${ }^{163}$ of a popular sovereignty from which law derives legitimacy (and not the other way around, as is the case for others, where law precedes and limits sovereignty. ${ }^{164)}$ This is "we, the people," and for Kahn, this refers not to mere majority rule; instead, popular sovereignty is a transhistorical project of a people creating and maintaining itself. ${ }^{165}$ This is obviously not the type of claim that a state could, on a legal view, invoke to object to foreign attack or intrusion. Claims of what we could call cultural sovereignty bear an uncomfortably close resemblance to claims of exceptionalism, ${ }^{166}$ and Kahn has not shied from the implication that exceptionalism of the American kind is perceived abroad (and with particular relevance for the interest of this essay, regarding the United States' unwillingness to be subject to the International Criminal Court,

\footnotetext{
163 This is made clear in Putting Liberalism in its Place, 10.

164 Kahn, "War Powers and the Millennium," 58.

165 Kahn, Putting Liberalism in its Place, 13.

166 Paul W. Kahn, "Sacrificial Nation," The Utopian, Vol. 6, March 10, 2010.
} 
specifically ${ }^{167}$ ) as an expression of naked interest by a sole super-power. The idea of American exceptionalism, however, predates its superpower status by two hundred years, and thus a justification for the exceptionalist view must be found elsewhere. Clearly, for Kahn, it is not a crude matter of power. Nor is exceptionalism grounded in considerations of justice, as the view that commands international law apply to all other states and not to the U.S. was-quite obviously-not determined behind a veil of ignorance. ${ }^{168}$ Instead, exceptionalism is more plausibly justified by the fact that America's popular sovereign and acts and speaks exclusively through the law. 169 "At that point," writes Kahn, "the exception becomes the exceptional, as in American exceptionalism." ${ }^{170}$ The reference to "the exception" here is made explicitly (and somewhat disconcertingly) to Carl Schmitt, a theorist with whom Kahn has engaged in greater depth in his recent Political Theology. ${ }^{171}$ Though Kahn has made plain that he wishes to bring "liberalism in contact with Schmitt," and not adopt his illiberal views-in particular those that base sovereignty on a prepolitical conception of a "people’s substantive homogeneity," 172 Kahn nonetheless adopts a Schmittian theoretical structure to discuss what he maintains is a view of American political faith in popular sovereignty, which in the discrete case of American society, runs precisely contrary to a homogenous view, demanding

\footnotetext{
${ }_{167}$ Paul W. Kahn, "Why the United States is So Opposed," Crimes of War Project, The Magazine, December 2003, <http://www.crimesofwar.org/icc_magazine/icc-kahn.html>. 168 Kahn, "Sacrificial Nation."

169 Kahn, Putting Liberalism in its Place, 20-21.

${ }^{170}$ Kahn, "Sacrificial Nation."

${ }^{171}$ Paul W. Kahn, Political Theology, (New York: Columbia University Press, 2011)

172 Kahn, Putting Liberalism in its Place, 20.
} 
instead that popular sovereignty accommodate a diversity of immigrant groups and faiths.

This view of exceptionalism, while it accounts for a secular devotion to U.S. sovereignty, as a reflection of American identity and a justification for sacrifice, does not begin to engage with, much less justify an American (or liberal) position towards the sovereignty of other states. Is the mere fact of exceptionalism sufficient to justify that a state would hold others to norms while simultaneously shielding itself from the institutionalized enforcement of those very same rules?

\section{Humanitarian Intervention}

Here, Michael Walzer can offer an account, though it may perhaps, when employed in this way, seem to focus too strongly on power. On the issue of humanitarian intervention, Walzer has argued that in the face of the commission of atrocities, those who can, should, intervene-and by intervention, what is meant here is military action. To rebut the implication that this moral claim anoints the powerful and the enlightened (who may well be the "we" to whom he refers affectionately, and which is described by Judith Shklar as “we,' his favorite characters"173) to act as Wild West vigilantes, Walzer instead relies on the examples of three let us call them "Third World" humanitarian interventions to demonstrate that proximity is sometimes the kind of "can" that leads to a 
"should," 174 that is an ability that generates an obligation to act. The problem with the cases that he cites-and this exemplifies a wider problem with doing justice through the infliction of military sentences without the benefit of a judicial institution to weigh evidence and sort out facts from rhetoric, however wellintentioned-is that all three "humanitarian interventions" could be reasonably justified as responses to aggression. Tanzania repelled Ugandan troops that were unlawfully on (and claiming) its territory; Vietnam responded to repeated aggressions on its territory by an increasingly bellicose Cambodia; and India (ultimately) responded to an aerial bombing of its territory by Pakistan. This is not to say that none of these military actions were undertaken with humanitarian justifications, or that their consequences were not to improve the lives of at least some civilians in the targeted states; the claim is that all three actions were justified under existing rules of international law and did not require additional humanitarian rhetorical support or deviation from (or for some, improvement of) the law as it stands. The concern here is to employ these cases to stand for the proposition that since civilians were exposed to a range of inhumane acts in Uganda, Cambodia, and East Pakistan, that these military responses were justified as cases of humanitarian intervention; blithely ignoring the fact that they were in all three cases justified responses to aggression is tantamount not only to rewriting the facts, but to creating rights of military actions on the basis of precedents that do not quite justify them. In other words, and this is in any event the prevalent legal and moral argument today, states are justified in attacking,

174 Walzer, Thinking Politically, "Beyond Humanitarian Intervention," 255. 
bombing, and invading others on the basis of humanitarian claims. Because Walzer does not think much of the United Nations' ability to provide "rescue and relief," 175 it is up to those who can, to do. Where does this leave the state? One could suppose that it depends on the state: some states have obligations to protect individuals abroad, while other states are argued out of existence, replaced instead by suffering individuals bearing rights to be rescued. ${ }^{176}$ Some states provide enforcement of rights for individuals on their territory-in fact, according to Walzer, what is unique to the state is "the description of rights enforcement as its central purpose"177-but in some cases, states, when they determine (on some good basis, but it is not quite certain what that would be, and how it is possible to always know for sure) that citizens of a foreign state are being massacred, have obligations to protect them, because no other entity can.

Analogies with domestic cases such as police are troublesome here because they fail to render the reality of international relations, or at best warp a proper analogy which would consider, for example, discretionary decisions of the police when to stop or not a speeding motorist ${ }^{178}$ as a decision made by some sort of police-like international entity, rather than by some state (presumably a powerful enough one). It makes a difference, when viewed domestically, whether one is stopped by the police-in which case one ought to accept the ticket or fight it in court-or by a burly motorist with a very powerful vehicle. In the latter case, not

\footnotetext{
175 Ibid., 253.

176 Ibid.

177 Ibid., 260

${ }_{178}$ Walzer, Thinking Politically, "The Argument About Humanitarian Intervention," 250, responding to Edward Luttwack's objection that a rule fails to be moral if it is applied sometimes but not others.
} 
only is the legitimacy of the intervention highly questionable, but what will come of it is unpredictable. In a civil society, it may be an unlawful act; in a Hobbesian state of nature, it looks like par for the course.

The difference, internationally-and the locus of the debate, really-is whether there exists anything tantamount to a police force, or a court, or some kind of locus of adjudication or of reasonable deliberation.

Kahn, too, has addressed the question and while less sanguine than Walzer about humanitarian intervention, he cannot articulate a reason why law-or antiquated arrangements at the UN level (antiquated presumably since they correspond to a cold-war logic)-ought to prevent states from ameliorating the lot of others. ${ }^{179}$ The problem is not, in Kahn's view, a surfeit of questionable interventions, but rather the failure to carry out humanitarian intervention consistently around the world. ${ }^{180}$

Moreover, it is difficult for Americans to adopt or ratify foreign or international human rights norms, as is evidenced by the exasperatingly slow pace of adoption of the Genocide Convention, the International Covenant on Civil and Political Rights, the additional protocols to the Geneva Conventions, the Convention on the Rights of the Child, and the Rome Treaty on the International Criminal Court. This is largely because, Kahn argues:

The United States was the first modern state, forming itself under a constitutional ideal of democracy and law. It is the country most deeply

179 Kahn, "War Powers and the Millennium," 51-53.

180 Ibid., 57. 
committed to an idea of itself as a sovereign entity under law. And it is the most spectacularly successful state in all of modern history. Only in the United States is the view deeply held that we have no need of the new global order of law: we have no such need because our nationalism has been a nationalism of rights under law for 200 years. ${ }^{181}$

The expression of popular sovereignty accommodated itself well with the cold war arrangement, as it protected America's territory and political conception of the law. ${ }^{182}$ It is the emerging project of global human rights that seems to disorient, though Kahn does not account for the fact that first, the human rights project-whether it be embodied by the United Nations, the International Covenant for Civil and Political Rights, or the Convention the Rights of the Child (to name only those)-is hardly an "emerging" cold war development. As for the post cold-war human rights agenda, observers of international law can be forgiven for thinking that the vast majority of the initiatives to change the international landscape were American. The first Gulf War, the establishment of two ad hoc criminal courts in 1993 and 1994 (as well as hybrid courts subsequently), the NATO campaign against rump Yugoslavia in 1999, and the unilateral war against Iraq in 2003 did more to vary the shape and content of the manner in which the international human rights project is advancing than any other initiatives since the cold war's end.

Humanitarian intervention, too, is not something that was forced upon the United States; and it is not the invention of developing nations in the seventies. It represents something worth sacrificing life for, in Walzer's view, since it is an act

\footnotetext{
${ }^{181}$ Ibid., 59.

182 Ibid., 57.
} 
of collective agency by the state, and though lives may be lost, the life of the state intervening is not at stake, it will live on. ${ }^{183}$ This argument appears to be meant to solve the "Good Samaritan" problem, that is the duty to help those who lives are in danger, but not at the peril of one's own life. Walzer shifts the question by envisaging the action as not risking the intervening state's sovereignty or territorial integrity. ${ }^{184}$ This move, while reassuring states that understandably seek to preserve the lives of their own citizens-seeking, as Walzer puts it, zero casualties of their own, ${ }^{185}$ opens the question of what happens to the target state. Is its territorial integrity and sovereignty not in immediate peril? If such infringement of sovereignty is to be properly compared to the lives of individuals tasked to carry out humanitarian operations, then it may be worth wondering about the whether any kind of fair procedural arrangement, or prior deliberation is not required before matters of such gravity are undertaken.

The sacrifice of individual lives, then, does not imperil the life of the state. The sacrifice is worthwhile as it is carried out on moral grounds, by this character, "we," to help "them." There is something disconcertingly similar in this assumption of sacrifice for the state (that will continue to live) to Kahn's more theological project, and his notion of sacrifice for the popular sovereign. There is something exceptional (or exceptionalist) in the view that "we," having determined that international regimes are ineffectual, or that human rights instruments cannot possibly apply to us (after all, didn't we write them in the first

\footnotetext{
183 Walzer, Thinking Politically, "Beyond Humanitarian Intervention," 256.

184 Ibid.

185 Walzer, Thinking Politically, "The Argument about Humanitarian Intervention," 244.
} 
place?) ought nonetheless take justice into our own hands. What warrants this arrogance, this epistemic certainty? ${ }^{186}$

The Problem of Legalism

The (usually, but not always) liberal commitment to legal principles has been described by political theorist Judith Shklar as "legalism,"187 that is "the ethical attitude that holds moral conduct to be a matter of rule following and moral relationships to consist of duties and rights determined by rules." 188 Legalism is a feature of most democratic societies, but can in addition constitute an ideology that denies "both the political provenance and the [political] import of judicial decisions." 189 Legalism illustrates the sort of formality that is required if judicial bodies established internationally (in the absence of supranational enforcement) are to be considered legitimate. It is worth noting, however, that legalism is both a tool of critical political analysis (as intended by Shklar) and a concept that has been reinterpreted by subsequent scholars and publicists as representing formalism as well as a (distinctively) liberal virtue. ${ }^{190}$

If international law is indeed moving from, as Kahn puts it, "a doctrine of state relations to a regime of individual rights,"191 this will likely lead to a highly individualized self-conception where rights-even internationally-precede other

\footnotetext{
186 Aleksandar Jokic, "Genocidalism," The Journal of Ethics 8 (2004): 251-97, 258.

${ }_{187}$ Shklar, Legalism, 1; Gary Jonathan Bass, Stay the Hand of Justice: The Politics of War Crimes Tribunals (Princeton: Princeton University Press, 2000), 20.

188 Shklar, Legalism, 1.

${ }^{189}$ Shklar, Legalism; Shirza Dossa, "Legal Liberalism: Law, Culture and Identity", The European Legacy, 4 (1999): 73-89, 73.

190 Bass, Stay the Hand of Justice, 6.

${ }^{191}$ Kahn, American Hegemony, 5.
} 
political commitments. ${ }^{192}$ Yet political commitments range more widely than to mere rights: families, community, the popular sovereign, and institutions of nondomination or of deliberation. Even if commitments do not-or ought notextend that far, if they are political by nature, they cannot be reduced to a narrow individual conception of rights without changing something fundamental in the nature of the liberal view. However important the law, procedure, and rights are to liberalism, on any account, they are important within institutions of the state. That is where these commitments emerge as politics, and it is in state institutions (whether those of deliberation or those of justice) that these liberal commitments thrive. In the continued absence of a truly genuine (that is universal) international enforcement of justice, the idea of a regime of individual rights replacing a doctrine of state relations is not only implausible, but seems, as it would reintroduce a kind of prepolitical anarchy, simply illiberal. Surely this is not the polis that liberal opponents of sovereignty would wish upon themselves.

192 Ibid. 


\section{Essay 2: The Costs of International Criminal Law}

"They were careless people, Tom and Daisy - they smashed up things and creatures and then retreated back into their money or their vast carelessness, or whatever it was that kept them together, and let other people clean up the mess

they had made." 193

International criminal law experienced an irresistible ascent after the United Nations Security Council, in 1993, unanimously interpreted the UN Charter to stand for the proposition that it had the power to establish criminal courts with the jurisdiction to prosecute and sentence individuals to incarceration for genocide, crimes against humanity, and war crimes. ${ }^{194}$ This was a remarkable development, and it is seldom sufficiently noted that it represented a marked departure from the content and architecture of the U.N. Charter, which set out as its subjects member states, and whose sovereignty the document explicitly guaranteed. Never was U.N. power over individuals even considered before then. Yet as the post-Cold War "peace dividend" bore witness to the dissolution of Yugoslavia and war in Europe, an unexpected opportunistic steeplechase to be the first state to offer an international legal remedy to a complex military and political problem unfolded in a matter of mere months; though the sudden reframing of armed hostilities as crimes had not previously been considered as something to be prosecuted before a new Nuremberg-style body, at least not by the Security Council before then.

\footnotetext{
193 F. Scott Fitzgerald, The Great Gatsby. (New York : Scribners, 1925) 180-181.

194 Resolution 827 of 25 May 1993, UN Doc. No. S/RES/827 (1993).
} 
The Secretary General of the U.N., Boutros Boutros-Ghali, hastened to offer a legal justification for the establishment of the ICTY, acknowledging that the Security Council's creation of a criminal tribunal might appear to be at odds with the contemporary understanding of how such a structure might formally be established. It bears noting here that generations of U.N. legal commissions had been vainly struggling to establish a permanent international court since its creation, and thus, at least within the U.N., a sudden international consensus (of at least the five permanent members of the Security Council) could surprise and warrant explanation. And so, Boutros-Ghali canvassed the "normal" approaches to the establishment of a court, namely through treaty (which has since come to fruition with the creation of the International Criminal Court, in force since 2002), or more controversially, through the vote of the General Assembly, deemed important, according to the Secretary-General, to point to states' "prestige" or perhaps to acknowledge some democratic, and more representative element in decision-making that was lacking in the Security Council's decision. The reason this type of process would be circumvented, according to BoutrosGhali, was urgency. There was simply no time to wait for states to ratify a treaty or for the General Assembly to agree to create an international criminal court. And over twenty years on, with ICTY prosecutions still taking place (and eleven years after the Security Council's decision that the ad hoc bodies wrap up their operations, in accordance with their completion strategy) it is possible to question whether urgency could ever apply to international criminal law (or any type of judicial litigation at all). 
International criminal law progressed rapidly; the International Criminal Tribunal for Rwanda was established in 1994, with its first trial beginning in 1997, as the movement to ratify the Rome Statute, which would create the long awaited International Criminal Court, gathered steam and gained plaudits from well-meaning scholars and activists (as well as some political entities, such as the European Union) who drove the process.

A number of other courts, whether international (that is Security Council created) or hybrid (that is established and run by a state alongside the United Nations) also emerged in the heady late nineties and first decade of the $21^{\text {st }}$ century: the Sierra Leone Special Tribunal, the Cambodia Special Chambers, the East Timor Court International Court of Justice, as well as the Lebanese Special Court, which is devoted to a single event, the assassination of Rafik Hariri. On December $30^{\text {th }}, 2006$, Saddam Hussein was hanged after a rather egregious show trial, which by the admission of some of international criminal law's leading scholars was organized by United States, 195 and which featured the little-known murders of three defense counsel by gunmen. ${ }^{196}$ The Iraqi special court is nowas are uncomfortably large swaths of the country-currently defunct, but the other courts slouch and lumber on, despite their increasing lack of credibility or geopolitical relevance, and in some cases, struggling with funding.

\footnotetext{
195 Michael A. Newton, Enemy of the State: The Trial and Execution of Saddam Hussein, First Edition edition (New York: St. Martin's Press, 2008).

${ }^{196}$ Kirk Semple, "Saddam Hussein Is Sentenced to Death," The New York Times, November 5, 2006, sec. International / Middle East, http://www.nytimes.com/2006/11/05/world/middleeast/o5cnd-saddam.html.
} 


\section{Towards Demise}

Two recent ICC cases illustrate a shift in ICL's legitimacy; both concern Africans and both demonstrate how ICL coincided fully with instances of regime change as well as the destabilization of the Middle East and North Africa. In 2011, Western media and politicians began to describe events unfolding in the area as the "Arab Spring." Very quickly, faced with reports of atrocities committed (or about to be committed) by Libyan political and military officials to quash demonstrations demanding greater democracy, the United Nations Security Council unanimously passed Resolution 1970, which, inter alia, referred the matter to the ICC, leading to the eventual indictment of Libyan leader Muammar Gaddafi, as well as to air strikes, regime change, and finally to Gaddafi's lynching and death, filmed and posted online. Other senior officials of the Jamahiriya remain indicted, but Libya has challenged the ICC on the basis of the Rome Statute's complementarity provision: lawyers representing Libya argued that it was willing and able to carry out the prosecution, which would supersede the ICC's referral jurisdiction.

As it stands, Saif al-Islam, Gaddafi's son, has had his ICC indictment confirmed by the Appeals Chamber, yet he is being held in the town of Zintan by a non-state armed group, and had appeared for a court date via videoconference. ${ }^{197} \mathrm{He}$ had been denied access to defense counsel, according to

\footnotetext{
197 Antonia Molloy, "Saif Al-Islam Gaddafi, Son of Libya's Former Dictator, to Go on Trial for War Crimes," The Independent, accessed September 19, 2014, http://www.independent.co.uk/news/world/middle-east/saif-alislam-gaddafi-son-of-libyasformer-dictator-to-go-on-trial-for-war-crimes-9257593.html.
} 
Amnesty International. ${ }^{198} \mathrm{He}$ was sentenced to death by firing squad by a tribunal constituted by a non-internationally recognized Libyan faction in Tripoli, that does not have actual access to al-Islam. Abdullah Senussi's trial, the ICC Appeals Chamber held, could take place in Libya, where he was sentenced to death in the same trial. It is difficult at the time of this writing to imagine stable conditions under which something like a criminal trial of this significance could be carried out fairly and transparently, if at all, and in fact the trial has been denounced as a travesty of justice, without defense lawyers, cross-examination, or even evidence. 199 The sentence is currently being reviewed by the Libyan Supreme Court.200

Another case bears mentioning here, as I attempt to brush, perhaps with broad strokes, a picture of the current political state of ICL. In 2011, as well, Ivory Coast president Laurent Gbagbo was arrested by a combination of U.N., French troops and militias loyal to his opponent in highly contested Presidential elections followed by political and ethnic violence, then sent to the International Criminal Court. Gbagbo's opponent, Alessane Ouatarra, a former IMF economist, claimed he had won the elections and the dispute was subsequently heard by the Constitutional Court, which found in favor of Gbagbo. Violence and opposition to the decision continued, but Gbagbo was inaugurated, with charges being

198 http://www.amnesty.org/en/news/libya-must-surrender-saif-al-islam-al-gaddafiinternational-criminal-court-2013-09-18, accessed December 20, 2015. 199 Robert Fisk, "Abdullah Al-Senussi Execution: This Perversion of Justice Suits Western Security Services Just Fine," Voices, The Independent, accessed December 12, 2015, http://www.independent.co.uk/voices/abdullah-al-senussi-execution-this-perversion-of-justicesuits-western-security-services-just-fine-10433785.html. 200 "Profile: Abdullah Al-Senussi," BBC News, accessed December 12, 2015, http://www.bbc.com/news/world-middle-east-17414121. 
exchanged on both sides that orders had been formulated to kill, beat, and rape protestors. Gbagbo's trial illustrates both progress and perversion in ICL: on the one hand, he was only officially indicted three years after his arrest while remaining in custody in The Hague, partially as a result of the court having given the Prosecutor an additional year to come up with evidence to support, not a finding of guilt, but the confirmation of the charges against him. On the other hand, the indictment decision features a spirited dissent that laments that the new evidence tendered by the Prosecutor relies primarily on "anonymous hearsay," and moreover, fails to make a compelling case that Gbagbo ordered, or even knew that violence would be carried out against civilians. ${ }^{201}$ The latter development is certainly positive, and stands in stark contrast to the practice back in the 1990s, when ad hoc courts, would, like New York Grand Juries, to quote Sol Wachtler's infamous phrase, “indict a ham sandwich.”202

I cite these last two cases to introduce a current picture that is much bleaker than the narrative of progress that sustained the forward march of everexpanding international criminal law in the past two decades. Intervention in Libya has proven less than optimal, to put it mildly, and the trials envisaged by the Security Council in 2011 seem not only dysfunctional, but derisory. The benefit of a criminal prosecution (or "accountability," in Security Council language, or indeed some conception of "justice") seems out of proportion with the costs of geopolitical instability.

\footnotetext{
${ }^{201}$ Dissenting Opinion of Judge Christine Van den Wangeart Dissent http://www.icccpi.int/iccdocs/doc/doc1783397.pdf accessed December 20, 2015. 202 Glenn Harlan Reynolds, "Ham Sandwich Nation: Due Process When Everything Is a Crime," Columbia Law Review 113 (2013), 102-108.
} 
And so today, some of the most sanguine voices in favor of international trials are now beginning to doubt that the project can survive in its current form. Mark Osiel, who once passionately called for "atrocity trials" to create collective memory through the judiciary's spinning of "vivid yarns," 203 penned a detailed and pessimistic account of international law, titled "The Demise of Criminal Law." ${ }^{204} \mathrm{He}$ canvasses a number of disappointments with the institution of international criminal law (at times conflating it with human rights law) and deserves great credit, as an ardent proponent of international trials, for setting some terms of discussion and argument, and for a candidly expressing his dour scholarly mood. Osiel's list of grievances also provides the opportunity to illustrate what is lacking in his critique (that I want to address as a type rather than a token approach to ICL) and how it fails to address not only the specific historical and political conditions that led to the institutions' emergence, but the fact that these historical conditions are in part responsible for the tribunals' downfall.

I certainly share Osiel's disappointment with international criminal law, but some of the reasons for that disillusion differ; moreover, mine is of a far more long standing nature. He argues that the future of ICL depends on the survival of the International Criminal Court, specifically, and questions whether it has achieved the abysmally low standard of "better than nothing." I shall return to the

203 Mark J. Osiel, "In Defense of Liberal Show Trials-Nuremberg and Beyond," in Perspectives on the Nuremberg Trial, Guénaël Mettraux, ed. (Oxford: Oxford University Press, 2008), 704. 204 Mark Osiel, “The Demise of International Criminal Law," accessed July 29, 2014, http://www.humanityjournal.net/blog/the-demise-of-international-criminal-law/. accessed July 29, 2014, http://www.humanityjournal.net/blog/the-demise-of-international-criminal-law/. 
question of alternatives to international criminal trials, namely economic and social justice as well as the question of economic inequality, but Osiel points to something quite different: he concludes that the ICC, for its "constituency," has fallen short, in ways that may prove fatal, to offer more than nothing. He first laments that among the respectable number of states that have ratified the Rome Statute, too many have done so cynically, in order to secure foreign direct investment, rather than with the intent of credibly committing to the ICC's jurisdiction. The implication, of course, is that states seeking foreign investment-developing nations-are the least credible. Criticism is also leveled against the foreign donors, who Osiel contends have insufficiently tied aid to the domestic prosecution of international crimes. The European Union is also at fault for not having insisted on trials of Communist-era crimes, and having instead accepted that post-Soviet states undertake more modest commemorative approaches to their past. It is unclear what type of international crimes Osiel believes went unpunished in the non-examples he provides, or how retroactive domestic (or international) legislation could plausibly serve to prosecute them. Considering collective memory to be shabby in comparison to trials, he reveals that his own commitment to judge-sanctioned collective memory was never meant as a grass-roots process of local reconciliation, but rather a top-down pedagogical initiative in which foreigners teach natives the benefits of liberalism. Osiel has in fact argued in favor of liberal show trials, "monumental spectacles," he writes, with no apparent sign of irony; "yarns," "narratives," and "stories" that would require prosecutors to familiarize themselves with the local conventions of 
narrative genres. ${ }^{205}$

Osiel continues his foray into the current state of international criminal law by addressing the growing interest scholars have shown for domestic prosecutions of international crimes. This would put the ICC in a kind of supervisory role, exercising soft power by pressuring states to carry out their own prosecutions, failing which The Hague would step in. Not only does Osiel express discomfort with this self-effacement tantamount to "self-erasement" of the ICC as an institution, he does not think history has demonstrated that states tend to adequately prosecute their own crimes. This is not meant in the ordinarily understood sense that leaders tend not to arrest and prosecute themselves for war crimes or genocide; instead, Osiel points to the record in Latin America, deploring the fact that post-dictatorship states have preferred "populist" trials prosecuting the financial offenses committed by previous regimes, believing that to be more acceptable to the people than prosecution of atrocities in which large swaths of the population may have been complicit.

This barely concealed contempt for financial prosecutions points to a key phenomenon: the power to frame what counts as a crime-the non-prosecution of which fosters what human rights and international criminal law activists and scholars of the nineties called "the culture of impunity"-deserves scrutiny, particularly in light of the correlation between the increase in interest in prosecuting atrocities (abroad) and the actual decrease in the prosecution of high-level financial crimes in the United States. "Too big to fail” was 
accompanied by “too big to jail," 206 as in 1999, Federal guidelines were introduced, inviting US prosecutors to take into account the interests of shareholders in the exercise of prosecutorial discretion. ${ }^{207}$ A single banker has faced criminal charges since the 2008 financial crisis, a situation that stands in stark contrast to the vigorous prosecutions for fraud and other offenses after the 1980s Savings and Loans scandal. The question that emerges from this empirical observation-and which is evident from Osiel's complaint, is whether there is a kind of trade-off between economic criminal justice (prosecutions for privatesector fraud or public corruption) and the prosecution of atrocities, whether within a given state-these are the examples Osiel has in mind-or the preference for spectacular prosecutions abroad to the detriment of domestic economic crimes. In other words, is it possible to detect a link between the two phenomena, in particular in terms of political choices about justice, and indeed, about the idea of equality?

Osiel's position should be familiar to students of the field of "transitional justice," an array of causal and normative theories that would govern accountability once autocratic states experience a shift to at times fragile democracy. Typically, the field of transitional justice favors legal and institutional responses to past crimes, such as the torture of political opponents of former

\footnotetext{
206 Andrew Ross Sorkin, "Realities Behind Prosecuting Big Banks," DealBook, accessed September 10, 2014, http://dealbook.nytimes.com/2013/o3/11/big-banks-go-wrong-but-pay-alittle-price/.

${ }^{207}$ Jed S. Rakoff, "The Financial Crisis: Why Have No High-Level Executives Been Prosecuted?, The New York Review of Books, January 9, 2014, http://www.nybooks.com/articles/archives/2014/jan/o9/financial-crisis-why-no-executiveprosecutions/.
} 
"third wave"208 regimes (Argentina being the prime example as well as the case study that led to a formal articulation of transitional justice under the auspices of the Aspen Institute, funded by the Ford Foundation in 1988), ${ }^{209}$ over other (politically plausible) justice claims addressing inequality or the redistribution of wealth. Transitional justice, as Paige Arthur, in a commanding study of the emergence of the field puts it, in particular in those cases where prosecutions of former political and military leaders were held, then suspended, as a result of political backlash, as in Argentina, the questions at stake went beyond simple accountability: "How to balance competing moral imperatives, reconcile legitimate claims for justice with equally legitimate claims for stability and social peace, and foster the relationship between justice for crimes of the past and a more just political order in the present." 210

Osiel's unwillingness to broach the record of domestic prosecution of atrocities with the nuance that Arthur demonstrates does a great disservice to those the whole enterprise purports to serve: the people, or more accurately, the citizens and legal residents of a given state. He claims, without providing evidence, that public opinion supports prosecutions for corruption and the kinds of government fraud that anger populations harmed by economic scarcity due to inequality, a view that canny prosecutors will seize, in his contention, to choose to prosecute those types of crimes to the detriment of more serious international

\footnotetext{
${ }^{208}$ Samuel P. Huntington, The Third Wave: Democratization in the Late 2oth Century (Norman: University of Oklahoma Press, 1993).

209 Paige Arthur, "How 'Transitions' Reshaped Human Rights: A Conceptual History of Transitional Justice," Human Rights Quarterly 31, no. 2 (2009), 322.

${ }_{210}$ Arthur, "How ‘Transitions' Reshaped Human Rights,” 323.
} 
offences, such as torture. Even were the claim to be empirically true, and acknowledging that it is problematic to refrain from the prosecution of serious offenses against the person (though there may be, as in the case of Argentina, important political reasons to suspend these cases, such as the choice of avoiding a coup to protect the new democratic government), another question emerges: so what if the collective good, honest officials, and fair distribution of wealth matter to people?

\section{The Politics of Human Rights}

The period in history when transitional justice emerges as a disciplinearguably the bridge between the explosion of human rights and the later surprising establishment of international legal bodies-predates the end of the cold war. A brief history of the emergence of human rights is required here, and some remarkable revisionist accounts have challenged the idea that human rights, viewed as a supra-national endeavor, have been with humanity, or the West, depending on the account, since time immemorial. Samuel Moyn patiently demonstrates that human rights, as understood today, emerged only in the midnineteen-seventies, having been, despite claims to the contrary, fairly marginal before then, at least as an international norm to be applied or enforced abroad. Indeed, after discarding the "uncritical wonderment" of the historiography of human rights, so frequently immersed in a teleological "church history" 11

\footnotetext{
${ }^{211}$ Moyn, The Last Utopia, 6.
} 
searching for past evidence upon which to identify the long roots of the irresistible ascent of human rights, he identifies the first genuine expressions of the phenomenon, more properly then understood as "the rights of man and the citizen" in Enlightenment revolutions.

While acknowledging that some ancient Greek thinkers (the Stoics), some aspects of Judaism, medieval Christianity, early-modern philosophy, abolitionists and antiracists certainly incorporated elements of morality-this is hardly a revelation-enforceable rights emerge only as does the secular state, and these rights are owed by the state to its citizens; it was inconceivable then, however internationalist was the French or the aftermath of the American revolutions that these rights were meant to apply to the peoples of other states. ${ }^{212}$ Enlightenment human rights are rights of citizens (and in the case of France, citizenship is extended quite generously during portions of the Revolution) and it is indulging in anachronism to entertain the idea that anyone conceiving of these lofty ideals at the time thought that they looked anything like they do now, something that would seek to transcend the authority of the state rather than rely upon it entirely for its fulfillment. The Rights of Man movement, posits Moyn, predates the human rights movement, "and it was called nationalism."213 Moyn's argument is based not only on the genuine lack of historical enthusiasm for these kinds of international rights over most of history-including, quite significantly, at the time of the adoption of the United Nations Universal Declaration on Human Rights, when they were not only marginal, but crucially addressed states-he

${ }^{212}$ Samuel Moyn, Human Rights and the Uses of History (Verso, 2014), 138. 213 Ibid. 
instead contends that human rights should be seen as a utopia that only emerged when various conditions interacted unexpectedly.

Moreover, human rights could only emerge as an ideal after other universalist utopias had lost steam and were on the brink of collapse. For Moyn, in parallel with the ascent of increasingly mainstream human rights NGOs such as Amnesty International and Helsinki Watch (today's Human Rights Watch)— and they became mainstream only when they began pointing to abuses committed in Warsaw Pact countries in addition to their more traditional focus on Latin America-came a certain disillusionment with the promise of decolonialization and self-determination. ${ }^{214}$ Indeed, Moyn demonstrates persuasively that what occupied the decades of idealism after World War II was not the idea of individual rights, (and much less as a reaction to the Holocaust ${ }^{215}$ ) but rather the struggle by formerly colonized states to achieve independence and self-rule. But by the early 1970s, anti-colonialism, writes Moyn, was believed to be "shipwrecked as a moral and political project." ${ }^{216}$ The bloom had faded from Western enthusiasm for the swashbuckling third world revolutions of Che Guevara and his comrades-in-arms, ${ }^{217}$ as many newly independent states eventually settled into plutocracy and client-based politics that had failed to deliver the egalitarian promises post-colonialism had within its reach but failed to fully grasp and realize.

\footnotetext{
${ }^{214}$ Moyn, The Last Utopia, 118. 215 Moyn, Human Rights and the Uses of History, 92. 216 Moyn, The Last Utopia, 118. 217 Moyn, The Last Utopia, 116.
} 
Those very emerging third world plutocracies are today associated with what Nils Gilman calls "deviant globalists," criminals who entertain a symbiotic relationship with a decaying state-and the phenomenon is not limited to the developing world. ${ }^{218}$ First World plutocrats erode Western democracy through lobbying and corporate personhood, while still parasitically enjoying its "legacy goods of social welfare," 219 then sending their profits and earnings to tax havens abroad, while global criminals-not those who interest the world of international criminal law and its tight focus on atrocities, but rather, drug and human traffickers, rare wood and earth dealers, illegal coltan miners, among others, who carve out bedeviling microsovereignties in post-colonial states. ${ }^{220}$ This "Twin Insurgency" emerges precisely at the same time as the idea of human rights. In Gilman's historical sketch, the post-World War II developed world promoted a largely social welfarist model, with states favoring the expansion of a middle class that could expect both increasing economic improvement as well as the state's provision of public goods through non-punitive progressive taxation.

The existence of the more radical egalitarian alternative of the Soviet Union, Gilman contends, provided a cold war incentive for social justice in Western nations. In these circumstances, inequality decreased within states in most of the developed world, and a middle class (or the industrial labor force in the communist space) could also consume goods produced within the state. It is uncontroversial to situate the beginning of the major political and economic shift

\footnotetext{
${ }_{218}$ Nils Gilman, "The Twin Insurgency," Features, accessed August 12, 2014, http://www.theamerican-interest.com/articles/2014/o6/15/the-twin-insurgency/.

219 Ibid.

220 Ibid.
} 
from this broadly Keynesian (in the West) approach in the 1970s, which is also when labor unionism began its US decline and the share of income going to the top $10 \%$, which had fallen sharply in the late 1930 s, started to increase gradually, reaching 50\%-last seen in the 1920 -by 2008.

\section{Unions and shared prosperity}

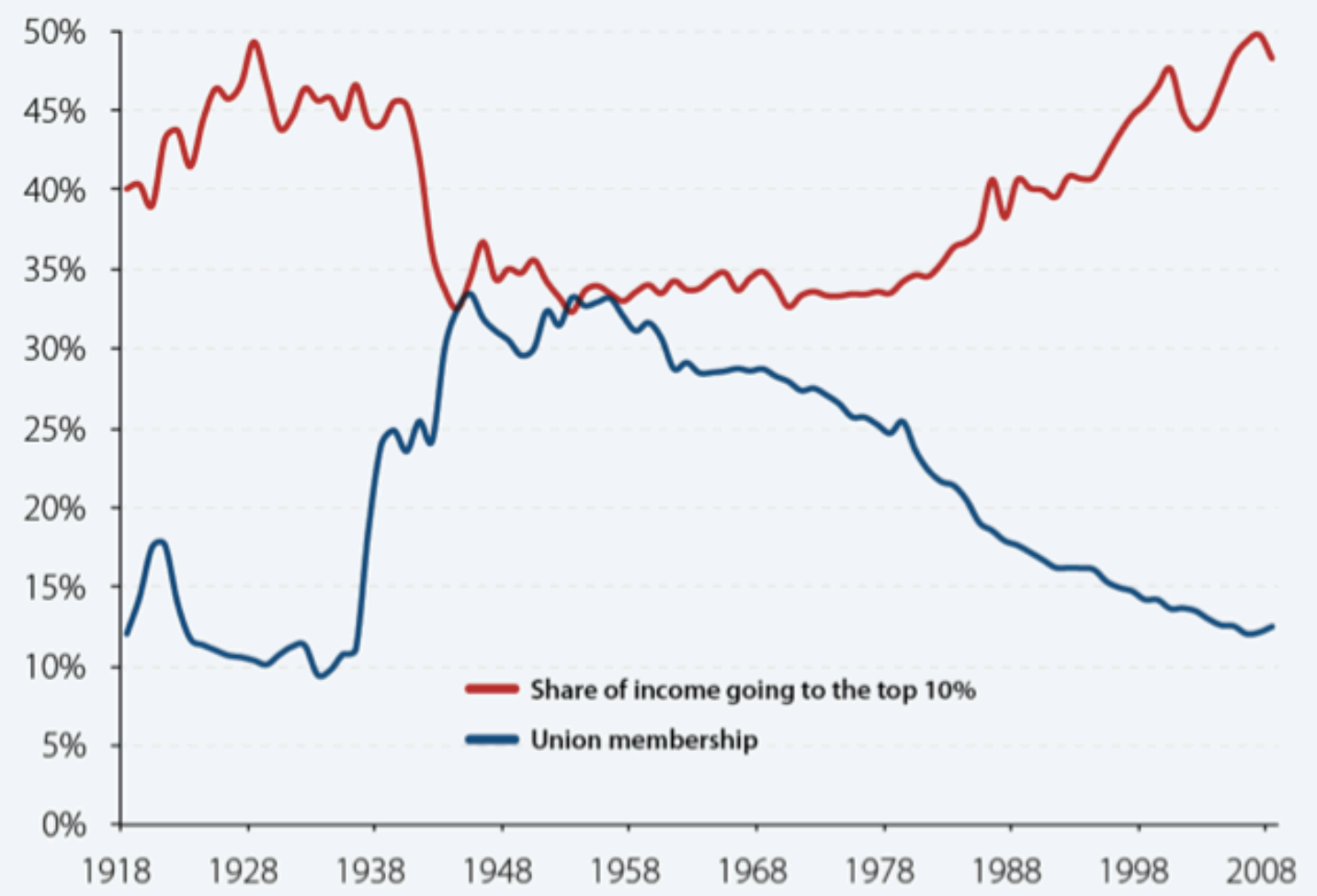

Source: Author's analysis of Historical Statistics of the United States, unionstats.com, Piketty and

\section{Figure 1}

An understanding and analysis of this period-as well the social trade-offs associated with it-are essential to understand the origins (and the eventual costs) of what seemed like a sudden shift towards international criminal 
prosecution of atrocities right after the end of the cold war. I will argue that it is not entirely unrelated to the inequality we have rediscovered in the Western world with Thomas Piketty's Capital in the Twenty-First Century ${ }^{221}$ or Gilman's deviant globalization.

Barbara Keys has added a remarkable study to the history of human rights scholarship, pin-pointing (as did Moyn before her) 1977 as the year the human rights ethos emerged in earnest. She shows, however, that this was a deliberate (though at first inchoate) political decision made by the Carter administration, to overcome collective guilt and shame in the wake of the Vietnam War. Human rights, as envisaged by the Carter administration, were no longer those "civil rights"-a painful reminder of social strife that shook the 50 and 60 s in the U.S. and deploring injustices within the country-but rather wrongs committed abroad by others, to be identified and remedied by the US, serving as what Moyn describes as "a tonic for the nation's self-confidence.”222 Though unsure, at first, of what these human rights would consist of, the Carter administration, influenced by New Left Democrats (the conservative democrats would lose the early definitional struggles but would reemerge under the Reagan, and crucially under the G.W. Bush administration ${ }^{223}$ ) promoted an idea of international human rights, with little cost to the U.S., and deployed this idea in opposition to the 1960 s Left opposition against "searing inequality and injustice," and rather to campaign against "individual evil perpetrated by small numbers of wrongdoers"

\footnotetext{
${ }^{221}$ Thomas Piketty, Capital in the Twenty-First Century, First Edition (Cambridge Massachusetts: Belknap Press, 2014).

222 Barbara J. Keys, Reclaiming American Virtue (Harvard University Press, 2014). 223 Ibid., 4.
} 
abroad. ${ }^{224}$ Keys' critical insight is that the foreign policy decision to adopt human rights was one of sentiment, to avoid the shame and guilt that resulted from the napalm, the strafing runs, My Lai, and the dishonor of Vietnam. The policy to defend human rights (abroad) would restore American virtue and a "proud, proselytizing moral role in the world." 225

Against the backdrop of the emergence of human rights in the 1970s, the phenomenon of transitional justice, which can be seen as a hybrid of human rights and domestic criminal law, more clearly emerges as a political and philosophical predecessor of international criminal law. Paige Arthur provides four main reasons for transitional justice's appeal in the 1980s: democracy was a desirable goal in many states undergoing political change from dictatorship; modernization theory had become discredited as an analytical and policy tool; states shifted from seeing transition as socioeconomic transformation and instead embraced legal-institutional reform; and finally, the "global decline of the radical left." 226

The human rights "revolution" of the 1970s-1980s stands for the internationalization of a formerly national idea, enforced domestically, through domestic legal or administrative institutions, which in its new incarnation, came to enjoy bureaucratic support, as an "embedded missionary agency"227 in the State Department Bureau of Human Rights and Humanitarian Affairs. Following

\footnotetext{
224 Ibid., 8.

225 Ibid., 271.

226 Arthur, "How ‘Transitions' Reshaped Human Rights,” 340.

227 Daniel W. Drezner, "Ideas, Bureaucratic Politics, and the Crafting of Foreign Policy," American Journal of Political Science 44, no. 4 (October 2000): 744, doi:10.2307/2669278.
} 
Ronald Reagan's election to the United States presidency, the administration first stated that international terrorism would take the place of human rights in foreign policy, but this intention, articulated by Alexander Haig and echoed by failed nominee to the key human rights post at the State Department, Ernest Lefever (who was not hostile to some degree of torture), ${ }^{228}$ was abandoned in favor of a more neoconservative vision of human rights by Elliot Abrams, who engaging in a certain amount of historical revisionism, framed the idea in a manner consistent with American exceptionalism, as "central to what America is and stands for." ${ }^{229}$ Human rights in U.S. foreign policy were thus redefined as democracy promotion, to be applied with some selectivity (that is not to allies), and as Keys puts it "emphatically did not include economic and social rights." ${ }^{230}$

Human rights were thus firmly established, defended by the National Endowment for Democracy as well as by Amnesty International. International criminal law, in contrast, was yet to enjoy institutional status: in order to emerge as a tangible corpus of law to be enforced before tribunals or in the words of Judith Shklar, "law-like political institutions," ${ }^{31}$ two other developments had to take place: first, the end of the cold war, and second, the emergence around the same time as the internationalization of human rights, of Holocaust memory.

\footnotetext{
${ }_{228}^{22}$ Barbara Keys, Reclaiming American Virtue, 273.

229 Ibid.

230 Ibid.

${ }^{231}$ Shklar, Legalism, 156.
} 


\section{Holocaust Memory in America}

Institutional memory typically consists of those legal acts of public commemoration established by a given state, such as the creation by a public law in 1980 of the United States Holocaust Memorial and Museum in Washington DC. ${ }^{232}$ Peter Novick devoted a controversial study of the "current concerns" that at the time led to the late emergence of Holocaust memory and its eventual institutionalization in America. ${ }^{23}$ The debate continues as to whether, as Novick (and also Moyn in an essay on the intersection of the emergence of human rights and Holocaust memory234) demonstrates, "Holocaust consciousness" was marginal following the end of the Second World War (and as Moyn further contends, largely irrelevant to the human rights concerns expressed in the Universal Declaration of Human Rights ${ }^{235}$ ) or whether significant evidence shows that Holocaust memory remained vivid in private memory and in Jewish subcultures. Little evidence exists of a salient Holocaust memory until the midseventies, whether in the United States or in Europe. ${ }^{236}$ The remarkable historian of the Holocaust, Raul Hilberg (a trained political scientist) observed in his memoirs-detailing with evident frustration the difficulties he had for decades publishing his formidable opus, The Destruction of the European Jews - that it was only at the time of the Vietnam War, when Americans were "searching for moral certainties" that the Holocaust could be a topic of interest, standing for

\footnotetext{
${ }_{232}$ Public Law 96-388. Law 106 - 292 - An Act To Authorize Appropriations For The United States Holocaust Memorial Museum, And For Other Purposes, 36 USC, chapter 23.

233 Peter Novick, The Holocaust in American Life (Boston: Houghton Mifflin, 2000).

${ }_{234}$ Moyn, Human Rights and the Uses of History, 91.

235 Ibid., 89-90.

236 Ibid., 91.
} 
absolute evil, against which "all other transgressions in the conduct of nations could be measured and assessed." 237

This statement by Hilberg, of course, bears striking similarity to the results of Barbara Keys' study on the emergence of human rights. And tellingly, Jimmy Carter's signing statement to public law 96-388, establishing the Holocaust Museum predictably said nothing about Vietnam, and much about the promotion of human rights. ${ }^{238}$ The temporal sequence that led to the proliferation of Holocaust memory (and its causes) is important as the USHMM was immediately the locus of two simultaneous things: the memory of Nuremberg (and the important role played by the United States in the prosecution of the Nazi war criminals) and calls for action to be taken by the United States in the former Yugoslavia, which were made at the opening ceremony, on April 22 ${ }^{\text {nd }}, 1993$, by Elie Wiesel in the presence of President Bill Clinton. ${ }^{239}$ Hilberg had lamented that the Holocaust museum, for which he served as an advisor in the early stages of its planning and creation, had, contrary to his own scholarly emphasis, failed to insist on the perpetrators and their sources. (Focus on the perpetrators, as well as Hilberg's insistence on the structural components of the Holocaust: the bureaucracy, the party, the military, and the industrialists, as well as the shift in decision-making, from public laws to something resembling anticipation or improvisation, was to some extent to blame for the hostile reception of his work

237 Raul Hilberg, The Politics of Memory: The Journey of a Holocaust Historian (Ivan R. Dee, 2002), 123.

${ }^{238}$ Jimmy Carter: "United States Holocaust Memorial Commission Statement on Signing H.R. 8081 Into Law. ," October 7, 1980. Online by Gerhard Peters and John T. Woolley, The American Presidency Project. http://www.presidency.ucsb.edu/ws/?pid=45232.

$239 \mathrm{http}: / /$ www.ushmm.org/research/ask-a-research-question/frequently-asked-questions/wiesel 
in the early years.) Hilberg had requested that a wall at the museum be covered with photos of perpetrators, known and unknown, representing these professional groups-Hilberg never failed to emphasize the key role of lawyers in facilitating the Holocaust, from the Nuremberg laws, to the niceties of expropriation and concentration-but instead, the wall ultimately displayed photos of the Nuremberg trials. "Some of the perpetrators," wrote Hilberg, "are still there, but in the role of defendant." 240

This is true, but it is useful to better understand what happened with these photos, to think not only about the perpetrators, but also about the experience of the visitor to the museum. For that, Novick's work-and research question, "why here, why now?"-are most instructive. Novick describes some puzzlement (both as a Jew and a historian) in discovering a museum that features exhibits that remind him of stations of the cross, with relics that strike him as fetishized objects that employ, most significantly, he writes, in the climax of Elie Wiesel's Night, crucifixion imagery, which resonate powerfully with major Christian themes while being only peripherally relevant in Judaism. ${ }^{241}$ This Christianization of the Holocaust is a phenomenon explored in Naomi Seidman's "Elie Wiesel and the Scandal of Jewish Rage," an examination of the shift between Wiesel's first publication of his experience at Auschwitz (and later Buchenwald), and the novel Night, that with the assistance of French Catholic and Nobel prize laureate François Mauriac, underwent significant changes that would prove appealing to Western audiences by toning down Wiesel's evident

${ }^{240}$ Hilberg, The Politics of Memory, 131.

${ }^{241}$ Novick, The Holocaust in American Life, 11. 
anger in his first Yiddish version of the book (Un di Velt Hot Geshvign, "And the World Remained Silent,” published by a small press in Buenos Aires), and instead supplanting that rage with the portrayal of a soulful, wise survivor, that in addition narrated events that were familiar to Christians, such as crucifixion imagery, or references to the Trinity. ${ }^{242}$ Night also abandons the political implications of the Yiddish original, in particular the demands for an end to what Wiesel saw as post-war German impunity. As Hilberg writes, again attempting to explain the hostility to his monumental empirical documentation of the Holocaust, there was a time when survivors were told to forget, "and when the Nuremberg trials were conducted not so much to understand Germany's history as to conclude unfinished business in order that Germany might be reconstituted with a clean slate in the North Atlantic community of nations confronted with the threat of communism."243

Another variant of Christianization has had distorting historical effects at the highest institutional levels. When President Jimmy Carter first set out to consider memorializing the destruction of the European Jews in the wake of an internationally successful NBC miniseries, Holocaust, he spoke of the six million victims of the Nazis, ${ }^{244}$ but was advised by domestic policy chief Stuart Eizenstadt to expand the number to eleven million, as the Simon Wiesenthal Center in

\footnotetext{
${ }^{242}$ Naomi Seidman, "Elie Wiesel and the Scandal of Jewish Rage," Jewish Social Studies 3, no. 1 (1996): 1-19.

243 Hilberg, The Politics of Memory, 70.

244 Novick, The Holocaust in American Life, 216; Public Papers of the Presidents of the United States: Jimmy Carter, 1978 (Washington, D.C., 1979), 813.
} 
California had done. ${ }^{245}$ The eleven million figure had baffled many, including the Israeli historian Yehuda Bauer. Indeed, five million non-Jewish casualties of the Third Reich is far too low a number to ever be accurate; conversely, if it is a measure of non-Jewish groups targeted for murder, it is far too high. So how was the figure arrived upon? Bauer reports that he asked Wiesenthal the question directly, and was told that he had simply invented it, ${ }^{246}$ ostensibly to present a more "ecumenical" figure to include victims of other (primarily Christian) faiths. In April 1979, both President Carter and Vice-President Mondale referred to the victims of the Holocaust as eleven million killed, 6 million of them Jews. ${ }^{247}$ The inclusive (and historically puzzling number) did not fail do draw the ire of Elie Wiesel, who found the number offensive. As Chair of the newly appointed President's Commission of the Holocaust, he insisted on, as Novick puts it, the "temporal as well as the conceptual priority of Jewish victimhood." 248 Concerns grew among White House staffers that Wiesel's opposition to the eleven million language, to be included in the President's executive order creating the Holocaust Memorial Council-the body that would go on to create the Holocaust Museum and Memorial in Washington, D.C.--might lead to his resignation, which would cause the administration to lose "the symbol of the Holocaust." 249 In the end, Carter's executive order did refer to the eleven million victims of the Holocaust, and Wiesel did not resign. What is left, however, is an institutional trace of an

\footnotetext{
245 Ibid, 217.

246 Ibid, 215.

247 Ibid, 218.

248 Ibid.

249 Ibid, 219.
} 
inaccurate casualty figure invented by Wiesenthal that became the first U.S. government-sanctioned definition of the Holocaust.

In addition to the Christianization of the Holocaust, which has served to give the event and its significance-arguably altered in the process-wider resonance, another phenomenon emerges with the Americanization of the Holocaust, made most evident by the Holocaust Memorial and Museum's placement adjacent to the National Mall in Washington, D.C. Optimism, argues Alvin Rosenfeld, was integrated into the American memory of the Holocaust, be it in the memory of Anne Frank ("In spite of everything I still believe that people are really good at heart" quoted by President Reagan during his trip to the Bergen-Belsen concentration camp in 1985), films like Sophie's Choice or Schindler's List, and finally, the Holocaust museum itself. ${ }^{250}$ A passage from a letter soliciting the support of new members sets out the "story" that visitors will experience: the extermination of the Jews, other groups, "and even innocent children." What follows is significant:

Then, finally, when breaking hearts can bear it no longer, visitors will emerge into the light-into a celebration of resistance, rebirth and renewal for the survivors-whether they remained in Europe, or as many did, went to Israel or America to rebuild their lives. And having witnessed the nightmare of evil, the great American monuments that surround each departing visitor will take on new meaning, as will the ideals for which they stand. ${ }^{251}$

\footnotetext{
${ }^{250}$ Alvin H. Rosenfeld, The End of the Holocaust, First Edition (Bloomington: Indiana University Press, 2011), 62-63.

${ }^{251}$ Ibid., 63.
} 
Here, the museum states that it not only commemorates (an event that took place in Europe), but perhaps even more importantly, celebrates the monuments that represent great American ideals, "fair play, decency, and justice for all." ${ }^{252}$ As Omer Bartov253 and Charles Maier wondered, why not build a museum to commemorate the American institution of slavery, ${ }^{254}$ Novick provides an uncomfortable answer: a reflection on enslavement and wrongs committed against African-Americans would imply reflections on redress, while the triumph of the Washington Mall over evil is "virtually cost-free: a few cheap tears." 255

Bartov further emphasizes that the Holocaust itself was committed by a highly efficient, modern state, a state much like ours, and whose features, he writes, we "would like to see exported to other parts of the world," ${ }^{256}$ in particular those economically inefficient places suffering from "epidemics, famine, and a general condition of brutality and savagery." ${ }^{257}$ Bartov then argues that if any lesson is to be drawn from the Holocaust, it is precisely that a society like oursour political and economic institutions, our mass psychology-could commit another such Holocaust, but that implication is far too subversive to be drawn from a publicly funded federal institution situated in its capital, ${ }^{258}$ among the great monuments to its national credo. Hilberg's observation about the photographs of the perpetrators becomes significant in the context of Bartov's

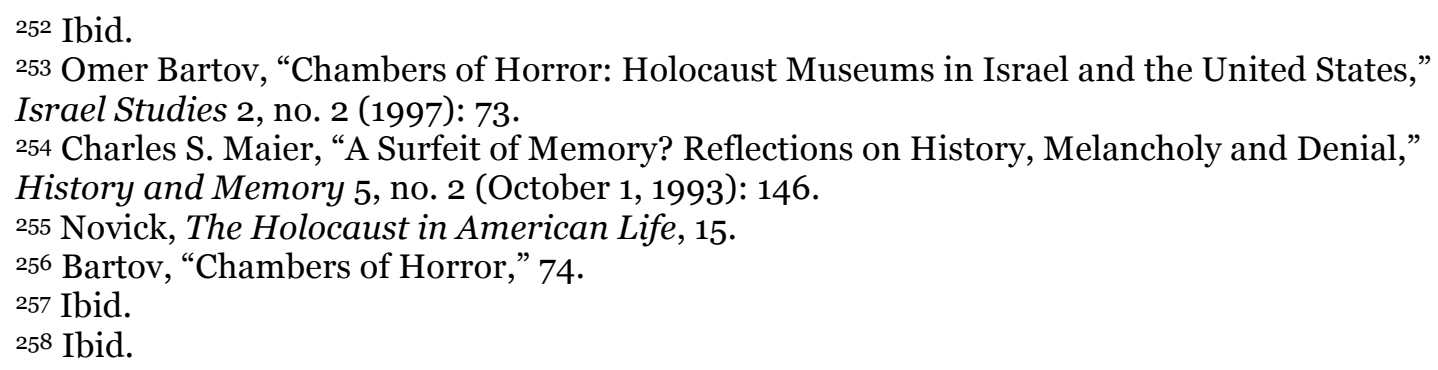


argument: instead of depictions of individuals who as lawyers, bureaucrats, servicemembers, industrialists, and party members, were the cogs of the machinery of destruction, and without whose work (familiar to us in a modern state) the Holocaust would not have happened as it did, we see some perpetrators on trial. It is worth recalling who tried them. Thus, we do not only see the perpetrators "in the role" as Hilberg puts it, of defendant; just as we see the monuments celebrating America's system of justice (for all) upon emerging "into the light," we see the American contribution to the prosecution of the Nazi leadership at Nuremberg. The Holocaust museum opened two months to the day after the United Nations Security Council established the International Criminal Tribunal for the former Yugoslavia.

Neoliberalism, Human Rights, and International Criminal Law

In a previous section, I have introduced a coincidence in the rise of human rights discourse, Holocaust memory, inequality, and the wider though unstated rubric of neoliberalism. Recent scholarship on the emergence of human rights from relative political or ethical marginalia to a forceful and effective mobilizing movement, in particular the groundbreaking work of Samuel Moyn, has first argued that human rights emerged as a utopia when other utopias ran out of steam; he also shows, however, that for the human rights movement to genuinely achieve purchase, it had to stake a non-political, minimalist and at times antistatist ground. This meant abandoning socioeconomic rights talk and focusing on 
individual rights, most often, as with the most powerful rights NGOs, such as Amnesty International and Human Rights Watch, of citizens outside the developed West. Furthermore, the U.S. adopted Human Rights as foreign policy, as shown by Barbara Keys, first fitfully, under the Carter administration, then more forcefully under President Reagan and since. The U.S. did not, quite obviously, have as a goal to defend redistributive rights abroad and much less at home.

In fact, in 1975, Daniel Patrick Moynihan published a rebuke to Third World demands for a new international economic order in Commentary, "in essence," writes Keys, responding "to the developing world's clamorous calls for a redistribution of wealth by saying: no, have human rights instead.”259 Moyn's leading historiography of human rights posits that the most interesting and useful unanswered question in scholarship consists in "grasping the eerie and disturbing conjuncture in which strong and costly solidarity at home collapsed in tandem with the popularity of weak and cheap solidarity abroad.”260 This emerges precisely when the U.S. adopts, even inchoately, human rights as policy, but also soon after Gunnar Myrdal and Frederick Hayek were jointly awarded the Nobel prize in economics, with their respective fortunes, in a rough symmetry with Moyn's “eerie and disturbing conjuncture," moving towards descent for Myrdal, and ascent for Hayek. Moyn points out that Hayek's policies saw their practical implementation in Great Britain, and the U.S. in the 1970s, a

\footnotetext{
259 Barbara J. Keys, Reclaiming American Virtue, 218." 260 Samuel Moyn, "Substance, Scale, and Salience: The Recent Historiography of Human Rights," Annual Review of Law and Social Science 8 (2012), 135.
} 
phenomenon that applied with less democracy and more violence in the Southern cone of South America. ${ }^{261}$

In parallel, as Moyn puts it, emerges the very strong idea-arguably stronger even in the institutions of international criminal law that followed-was that:

there was no summum bonum as the plausible object of striving, not even the capitalist welfare state once widely stigmatized for its lack of ambition and materialist soullessness. Instead, the summum malum of spectacular atrocity as the organizational fulcrum for moral consciousness and international conscience was put in its place." 262

Moyn has taken up a recent critique formulated in an important essay by British Marxist legal scholar Susan Marks that he, contrary to the engaged writer Naomi Klein, has failed to appreciate the influence of neoliberalism in the emergence of the 1970s human rights phenomenon in both a scholarly text as well as a more widely accessible internet publication. ${ }^{263}$

Before wading into the merits of the respective sides of the debate, in which I will introduce a via media-that is human rights neither as a "helpless bystander"264 nor as a "powerless companion" 265 of neoliberalim as with Moyn, and not as caused by neoliberalism, as with Marks, but rather as a reckless

\footnotetext{
${ }^{261}$ Samuel Moyn, "Human Rights and the Age of Inequality," Open Democracy, accessed December 10, 2015, https://www.opendemocracy.net/openglobalrights/samuel-moyn/humanrights-and-age-of-inequality.

262 Samuel Moyn, "Substance, Scale, and Salience: The Recent Historiography of Human Rights," Annual Review of Law and Social Science 8, no. 1 (December 2012): 123-40, 135. ${ }^{263}$ Samuel Moyn, "A Powerless Companion: Human Rights in the Age of Neoliberalism," Law and Contemporary Problems, 2014, Samuel Moyn; "Human Rights and the Age of Inequality," Open Democracy. 264 Moyn, "Human Rights and the Age of Inequality". 265 Moyn, "A Powerless Companion."
} 
opportunist-I shall first turn to a brief intellectual history of economic and political thinking focusing mainly on the 1970s, but certainly not constrained to that decade in regards, broadly, to the perception of equality, rights, and more broadly, democracy at the same time.

(A) Economics and Inequality in American Intellectual History

The year 1977 is now considered the signal year for the earnest emergence of human rights in most serious scholarship, but it is also the year that Charles Lindblom's controversial Politics and Markets was published. It received several scathing reviews across the scholarly and political spectrum (and from friend and foe alike), ${ }^{266}$ but also attention and acclaim by the New York Review of Books. ${ }^{267}$ The degree of interest in Lindblom's book was in part due to his unflattering observations-from a democratic standpoint-about the power of corporations in America, but perhaps even more so to the fact that Lindblom, Yale professor and with Robert Dahl, prominent proponent of pluralism theory, described somewhat harshly by Daniel Fusfeld as "this stalwart of the conventional wisdom, this academic pillar of the status quo," 268 appeared to have undergone an "intellectual and ideological transformation." 269 Others, less charitable still, particularly in light of their admitted friendship, likened Limblom's efforts to that of a Rip Van

\footnotetext{
266 Daniel Fusfeld, (1979) Three Reviews of Charles E. Lindblom: "Politics and Markets: The World's Political Economic Systems" Journal of Economic Affairs 13(1) 207-217; Charles W. Anderson, C. (1978) The Political Economy of Charles E. Lindblom. The American Political Science Review, 72 (3), 1012-1016; James Buchanan, (1979). Three Reviews of Charles E. Lindblom: "Politics and Markets: The World's Political Economic Systems" Journal of Economic Issues 13(1), 207-217; Robert Solo, (1979). Three Reviews of Charles E. Lindblom: "Politics and Markets: The World's Political Economic Systems" Journal of Economic Issues 13(1), 207-217. 267 Fusfeld, 209.

268 Ibid, 214.

269 Ibid, 215.
} 
Winkle, who had seemed to have slept through the 1960s. ${ }^{270}$ And perhaps not only the 1960s, as he seemed to have missed the storied debates and critiques that marked the decade so strongly, ${ }^{271}$ most notable of which was the 1960 publication of The Semisovereign People: A Realist's View of Democracy in America, ${ }^{272}$ in which E.E. Schattschneider famously quipped that "the flaw in the pluralist heaven is that the heavenly chorus signs with a strong upper-class accent." 273

Lindblom's general argument was that the idea of pluralism-developed, argues Ido Oren, as a research agenda to counter what the discipline considered to be the inherent totalitarianism of the Soviet Union at the height of the cold war ${ }^{274-h a d ~ f a i l e d ~ t o ~ t a k e ~ i n t o ~ a c c o u n t ~ t h e ~ d i s p r o p o r t i o n a t e ~ i n f l u e n c e ~ o f ~ b u s i n e s s ~}$ and corporate interests on political power, and that this phenomenon had disenfranchised the people-at least with respect to their control of government authority-and they had come, in addition, to accept that state of affairs uncritically. 275

Lindblom's concern resides in the fact that private enterprise, quite outside formal collaboration with governing institutions, makes decisions (as is

\footnotetext{
270 Buchanan, 216.

${ }^{271}$ An comprehensive account of these debates in to be found in John G. Gunnell, Imagining the American Polity: Political Science and the Discourse of Democracy, (University Park PA: The Pennsylvania State University Press, 2004).

${ }^{272}$ E.E. Schattschneider, The Semisovereign People: A Realist's View of Democracy in America (New York: Holt, Rinehart, and Winston, 1960).

273 Ibid, 31.

274 Ido Oren, Our Enemies and US: America's Rivalries and the Making of Political Science, (Ithaca NY : Cornell University Press, 2003), 95-98.

275 Charles Lindblom, Politics and Markets: The World's Political-Economic Systems, (New York: Basic Books, 1977); Fusfeld, 214.
} 
its nature in a capitalist economic system) relevant to a huge swath of economic organization, and that influence the lives of millions of people. ${ }^{276}$ Putting it bluntly, Lindblom revealed the tension between the idea of the great American democracy, and an institutional and economic reality that does not appear to fulfill the promise of pluralist theory. Of this theory, Fusfeld writes that it is:

[T] he socio-political theory of the 1950s that explained why the United States-whose economy is dominated by a few hundred giant corporations, whose politics is run by special interests and their allied bureaucrats, where at least 60 percent of the productive wealth is controlled by less than 2 percent of the families-why this society was the most truly democratic and beneficent that mankind had ever seen. ${ }^{277}$

The attitude revealed by Fusfeld, above, recalls Samuel L. Huntington's insight that Americans suffer from "cognitive dissonance," a condition caused by the gap between ideals-and in this case it would be pluralist theory-and the existing political institutions' inability to measure up to the standards of democracy. In Huntington's argument it is Gunnar Myrdal's “American Creed," embodying the ideals of liberty, equality, individualism, and democracy ${ }^{278}$ that has fallen short. Huntington emphasizes the ideal of equality as that which U.S. institutions has most disappointed-conceding the point regarding the distribution of wealth and in limited respects regarding the distribution of political power-citing de Tocqueville's "half right and half wrong" assessment of equality being the

\footnotetext{
${ }^{276}$ Fusfeld, 214.

277 Ibid, 210.

${ }^{278}$ Samuel P. Huntington, (1982) "American Ideals versus American Institutions," Political Science Quarterly, 97(1), 1-37, 1, 10.
} 
defining characteristic of American society. ${ }^{279}$ Half-right, empirically, at the time, argues Huntington, but not correct regarding a gradual evolution towards equality, at least not, as Lindblom discovered, where economic distribution of wealth is concerned.

It is worth noting that Huntington approached the problem of "his" cognitive dissonance by first characterizing the people's reactions as a mixture of moralism, cynicism, complacency, and hypocrisy 280 -in a manner not dissimilar to Lindblom's conclusion that in fact the people had lost the ability to take better into account business interests in their daily lives and by becoming slothful and acquisitive 281 -then, by engaging upon a comparative analysis of other polities which were, he argues, all institutionally improved by American foreign intervention. ${ }^{282}$ Thus he can claim that the gap between American ideals and American institutions vanishes when applied to the American impact on other societies. The similarity with the new human rights of the 1970 s as radiating outwards to wrongdoers abroad, rather than to inequality at home is striking.

The corporate sector is already a leviathan of an interest group, quite unlike the associations conceived of by de Tocqueville, Robert Putnam or even Michael Walzer, a fact rarely conceded by the pluralist theorists of Lindblom's generation..$^{283}$ They arguably benefit from at least four important advantages over

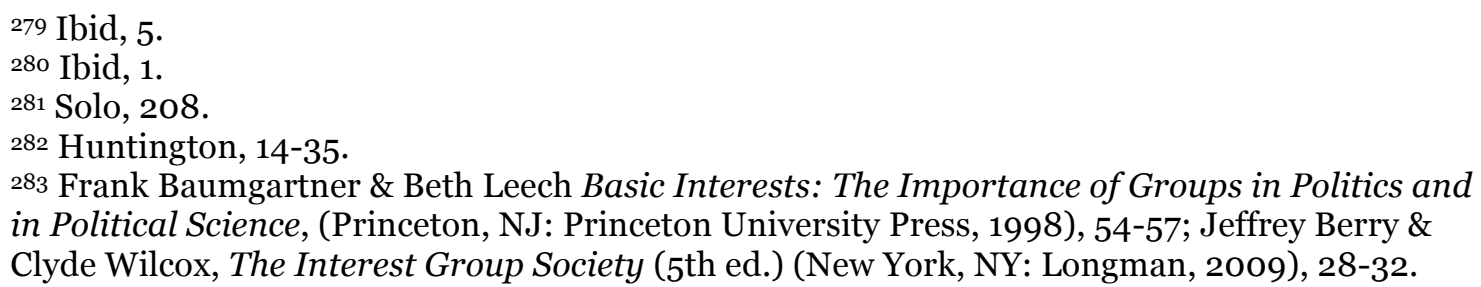


other groups, that is, resources in money, organization, access, and indoctrination. ${ }^{284}$ Furthermore, corporations have won a First Amendment challenge in Citizens United v. FEC, and may now devote unlimited financial resources to federal electioneering communications, and thus directly attempt to influence the electorate to (further) adopt corporate preferences in the public sphere. Since then, the Supreme Court in its 2014 McCutcheon v. FEC ruling took Citizens United further, “celebrating,” as campaign finance scholar Richard Hasen writes, "the idea of politicians responding to the wishes of big donors and spenders." 285 And in a dramatic finding reported well outside the confines of political science, ${ }^{286}$ Martin Gilens and Benjamin Page found that time and again, across policy areas, the interests of the wealthy are preferred over those of the general public as measured by policy outcome. In fact, average citizens were found to have little to no influence. ${ }^{287}$

As even eminent pluralists, in the 1970s, began to doubt the promise of economic equality, and indeed of democracy, just as human rights were invoked by the United States government against violators of individual rights abroad, it is easy to grasp why human rights talk would want to minimize demands in order to succeed as a movement. The idea of equality was already running dry as alarm bells rang against the expansion of corporate power, as the credo of equality was

\footnotetext{
284 Anderson, 1016.

285 Richard Hasen, Plutocrats United : Campaign Money, the Supreme Court, and the Distorsion of American Elections, (New Haven : Yale University Press, 2016), 5.

286 What in the world? Pieces of global opinion, "Study: US Is an Oligarchy, Not a Democracy," BBC News, accessed February 14, 2016, http://www.bbc.com/news/blogs-echochambers27074746.

${ }^{287}$ Martin Gilens and Benjamin Page, "Testing Theories of American Politics: Elites, Interest Groups, and Average Citizens," 12 Perspectives on Politics 564 (2014); see discussion in Hasen, Plutocrats United, 53-54.
} 
even explicitly discredited as a petulant populist demand by thinkers as influential as Huntington. The time was evidently ripe for human rights, then eventually international criminal law, as well as Holocaust memory in between.

(B) Powerless Companions and Neoliberal Stooges

Samuel Moyn has taken on, as we have seen, the charge that he has inadequately, as opposed to Naomi Klein, appreciated the contribution of market fundamentalism as a driver of the human rights movement as we know it, a minimalist enterprise. ${ }^{288}$ Susan Marks first deftly summarizes Moyn’s conclusions in his important 2010 The Last Utopia: Human Rights in History in a succinct paragraph:

In his words, human rights 'became powerful and prominent because other visions imploded'; they 'are best understood as survivors: the god that did not fail while other political ideologies did'. The 'god that failed' was, of course, communism, as seen by ex-communists who had repudiated it. But while Moyn highlights the 'anti-totalitarianism' of this period, he also stresses the 'anti-politics'. If human rights avoided failure, he explains that this was 'most of all because they were widely understood as a moral alternative to bankrupt political utopias'. Their success 'depended on leaving behind political utopias and turning to smaller, more manageable moral acts'. Human rights thus involved the 'substitution of moral for political utopianism'. They were a 'minimalist, hardy utopia that could survive in the harsh climate' of the post-oil shock era, with its straitened economic circumstances and 'mistrust of more maximal plans for transformation - especially revolutions but also programmatic endeavours of any kind'289

But Marks quickly shifts to a virtual retort she would have Naomi Klein make against Moyn's careful research into the conditions that allowed the frank

\footnotetext{
288 Ibid.; "Human Rights and the Age of Inequality" openDemocracy."

${ }^{289}$ Susan Marks, "Four Human Rights Myths" in Kinley, Sadurski, Walton (eds.) Human Rights:

Old Problems, New Possibilities (Edward Elgar Publishing, 2013), 217-235, 224.
} 
emergence of a movement that had previously labored in the shadows. For Moyn, this is the displacement of discredited political utopias in favor of minimal ones focusing less on summum bonum than on summum malum. Klein, according to Marks, also considered that human rights were truly born in the 1970s, however, states Marks, Klein points out what Moyn failed to mention: that human rights rise in the "period of the neo-liberal version of 'private' capitalism, with its now familiar policy prescription of privatisation, deregulation and state retreat from social provision". ${ }^{290}$ Marks adds that for Klein, "part of the context for the consolidation of neo-liberalism itself was the emergence of the human rights movement (...)"291 Unfortunately, that is not quite what Klein argues in the thirteen-odd pages she devotes to human rights in The Shock Doctrine, ${ }^{292}$ a book that though receiving plaudits on its book jacket (and beyond) did not fail to draw harsh criticism from both the left (how is this new?293) and from the right (selection bias, faulty causal reasoning, vulgar demonization of Milton Freidman ${ }^{294}$ ). In discussing the shift from a utopian left politics in the Southern cone to a more legalistic, human rights discourse, she tells the story about how groups were forced, because of the violence of state repression, to shift their strategies, and instead focus on appeals about disappearances, extra-judicial detention, and torture. The strategy of minimizing demands she recounts does not seem to substantially differ from Moyn's, and the idea that neo-liberalism

\footnotetext{
290 Ibid, 226.

291 Ibid.

${ }^{292}$ Naomi Klein, The Shock Doctrine: the Rise of Disaster Capitalism (New York: Metropolitan Books, 2007).

293 Doug Henwood, http://www.leftbusinessobserver.com/Shock.html, accessed 12/14/2015. 294 “Naomi Klein Smackdown Roundup,” The Economist, accessed December 14, 2015, http://www.economist.com/blogs/freeexchange/2007/10/naomi_klein_smackdown_roundup.
} 
could consolidate as a result of this adaptation-in a geographically limited case study-is suggested rather than affirmed, and then if only because these authoritarian neoliberal states' use of violence precluded other means of opposition. So, too, do the demands of students, leftists, trade unionists, and their clergy comrades, must, in the face of an army ready to shoot, and a police ready to imprison, be reduced from calls for redistribution to cries for help. Klein shows that human rights emerge as a strategy in these cases because of violence (and is that violence inherently neoliberal, or is it more accurately authoritarian?) but not that the shift to human rights did anything to enable, enforce, or consolidate neoliberalism.295 It is best described by Klein as its symptom, not its cause.

Marks also uncharitably, and it seems inaccurately, faults Moyn for desiring, if not prescribing, a minimal human rights devoted to "catastrophe prevention," and not grasping that anti-politics is a politics. ${ }^{296}$ Though Moyn has never taken the position the human rights have a causal link to inequality, he has consistently demonstrated that he is concerned with the problem of their coincidence, and has shown, if gingerly, dissatisfaction with the current minimal state of human rights affairs, contrary to Marks' contention. In response to these charges, Moyn has recently written that:

Unlike some Marxists, ${ }^{297}$ I think it is foolish to blame human rights for the explosion of inequality in our time, even though the former became

\footnotetext{
295 Klein, Shock Doctrine, 117-125.

296 Susan Marks, “Four Human Rights Myths,"226.

297 I wish to thank Samuel Moyn for responding to private correspondence querying who those

"Marxists" might be.
} 
globally prestigious just when the latter began. In a vulgar formula, neoliberalism, not human rights, is to blame for neoliberalism. The real trouble is that those systems of law and programs of action that have so far been established around socioeconomic rights have made of them neither an enabling tool, nor a threatening enemy, but a helpless bystander of market fundamentalism. ${ }^{298}$

\section{(C) Crafting a Via Media: Reckless Opportunists}

It is not certain that anyone-including "some Marxists"-have been sloppy (or foolish) enough to "blame human rights" for inequality. Moyn himself has pointed to the importance of the coincidence in the rise of both phenomena as an important and useful question in the historiography of human rights. ${ }^{299} \mathrm{He}$ points out that not only Marxists see a link between the two, but proponents of economic freedom have argued 300 that open markets promote human rights, citing Ernst-Ulrich Petersmann's301 unbridled free market optimism, as well as Philip Alston’s unambiguously clever response: “Petersmann's goal was “to hijack, or more appropriately to Hayek, international human rights."302

Surely Moyn is not as blind to the consequences of neoliberalism on the human rights movement of the 1970 s and beyond as Marks would have him, but in the end, following his own reasoning, he contends that a system that conceives

\footnotetext{
298 Moyn, "Human Rights and the Age of Inequality".

299 Moyn, "Substance, Scale, and Salience."

300 Moyn, "A Powerless Companion," 148

${ }^{301}$ Ernst-Ulrich Petersmann, "Time for a United Nations "Global Compact" for Integrating Human Rights in the Law of Worldwide Organizations: Lessons from European Integration," European Journal of International Law 13 (2002) 621, 621-22, cited in Moyn, "A Powerless Companion," 148.

302 Moyn, "A Powerless Companion," 148, citing Philip Alston, "Resisting the Merger and Acquisition of Human Rights by Trade Law: A Reply to Petersmann," European Journal of International Law 13 (2002) 815-16.
} 
of rights as a floor, with no interest in limiting or attaining (an economic) ceiling is simply too weak to affect rising inequality. ${ }^{303} \mathrm{He}$ concludes by assessing the limited goals of the current rights movement, and stating that only something much different, and more threatening could have the power to affect market fundamentalism:

To bring the limited aims and often glancing successes of human rights movements into focus is simply to demand another politics to supplement goals that are inadequate in the first place and strategies that rarely work, especially in the socioeconomic domain. A threatening enemy, rather than a powerless companion, is what market fundamentalism demands. 304

To be sure, rights that primarily, if not exclusively, seek to ensure the protection of fundamental freedoms (from catastrophe or atrocity) will not have the power to-nor the objective of-taming economic inequality. But to say that this conception is but a "helpless bystander" is mistaking the rights per se with the human rights movement as a sociological group, one with agency and the ability to make choices for the survival, and indeed the ultimate triumph of its aspirations. Yves Dezalay and Bryant Garth have employed the tools of structural sociology, developed by Pierre Bourdieu, to explore the dynamics of the field of human rights.305 "To understand the logic of the field, we examine how it was built and what ingredients became a part of it," they write. "This sociological and historical approach," they continue, "reveals power relationships that are obscured in words like "the international community," "norms," and the "law."

303 Ibid.

304 Ibid, 169.

305 Yves Dezalay and Bryant Garth, 'From the Cold War to Kosovo: The Rise and Renewal of the Field of International Human Rights', Annual Review of Law and Social Science 2, (2006): 231255. 
They conclude: "The "rules of the game" of the field determine the kinds of arguments, ideas, and actors that will be capable of transforming the field, or particular aspects of it. U.S. influence, [...], created a transnational field that not only privileges legalization, but also places U.S. campuses, the U.S. media, and the U.S. power centers of New York and Washington, DC, at the top of the hierarchy of actors and organizations." 306

If Moyn is correct in his assessment that the human rights movement rose to prominence as a result of the discredit of a former, be it redistributive, reformist, or plainly socialist utopia-and he has made a terribly good case that he is-it is worth examining whether or not the human rights movement made conscious choices to tailor rights as minimally as they did. Only then will it be possible to judge whether they are, with respect to inequality and to economic injustice "helpless bystanders," or as I prefer to put it, reckless opportunists.

By all accounts, human rights organizations made the conscious choice to scuttle socio-economic rights in order to streamline and mainstream their message; in today's cynical marketing parlance, we would speak of clarifying their brand. This certainly contradicts the idea that these movements stood like deer in the headlights before an unexpected neoliberal ten-ton truck: they had already known it best to dash away to the safe-haven of the atrocity and the war crime. Thus, no frontal impact did, during the most important period, occur. It is instructive to examine the views held by the former head of the ACLU and Human Rights Watch (HRW), Aryeh Neier, towards socio-economic rights, as 
these, at least as he has stated them, go well beyond a strategic decision to leave them aside for the sake of more important so-called first generation rights (also known as political rights, or as he put them, "negative rights," following Isaiah Berlin),307 but demonstrate evident political hostility to the very idea of economic rights. He "strenuously opposed," he writes, both at the ACLU and HRW, "efforts to deal with economic issues as rights." 308

Neier thus challenges the idea that what he calls economic issues can or ought to be construed as rights, 309 despite the inclusion of eight such articles in the Universal Declaration on Human Rights. ${ }^{310}$ Neier considers the concept of economic and social rights "profoundly antidemocratic," and adds that "authoritarian power is probably a prerequisite for giving (them) meaning." In light of the lack of evidence he presents, one can only conclude that this is an ideological preference, premised perhaps on his stated reliance on Aristotle's conception of distributive justice, opposed as is it to equals receiving unequal shares and unequals receiving equal shares in a given distribution. ${ }^{311}$ Neier claims to oppose the idea of economic rights because they somehow "diminish the protection of political rights," as he contends that economic issues concern expenditures by governments that may have different conceptions of, for instance, an adequate standard of living that may vary from place to place and

\footnotetext{
307 Aryeh Neier, Taking Liberties: Four Decades In The Struggle For Rights (PublicAffairs, 2005), xxxi. 308 Ibid, xxix. 309 Ibid, adding his "unwillingness to concede it is appropriate even to use the terminology of rights is discussion economic issues." 310 The United Nations. 1948. Universal Declaration of Human Rights. ${ }^{311}$ Neier, Taking Liberties, xxxi.
} 
from time to time. Thus, for Neier, "the language of universal rights should be reserved for matters where it is possible to insist on adherence to these same criteria everywhere.”312

The problem in Neier's reasoning is that he appears to assume that to view those UDHR economic rights as rights, necessarily undermines freedom of expression and association. He perhaps has some examples in mind where this may have been the case, but counterexamples abound showing that ensuring something like a non-discriminatory wage, or compulsory elementary education are not inconsistent with the exercise of democracy. Democracy is undermined, he argues, because economic rights claims do not trust "institutions and processes" that normally make decisions regarding the allocation of resources. That is not necessarily the case: democratic decisions can be made to promote more redistributive policies that coincide with the economic and social rights promulgated in the UDHR; so too can democratic decisions be made to restrict freedom of expression and assembly, as France has done in the wake of terrorist attacks in Paris of November 13, 2015. The compulsion to separate the two types of rights overlooks a legalist reality: the Declaration is a hortatory document, it is aspirational, and it did not spring fully formed like Athena from the head of Zeus, but was rather the result of compromise between cold war actors. ${ }^{313}$ Contrary to what Neier suggests, there are no enforceable political rights from which antidemocratic economic issues must be extracted to preserve the universalism of the former. Moreover, even the assumption some may hold that liberal states 
might have been forced to accept social and economic rights is not historically correct: Moyn provides the obvious reminder that social rights were not controversial at the time, they had been present in the French Revolution, and more recently in President Franklin Delano Roosevelt's proposal of a "Second Bill of Rights," as well as the interwar policies designed to tame the excesses of capitalism. ${ }^{314}$

Of course this will change during the Reagan era, when the administration's anti-big government measures drew curiously little resistance from human rights leaders, as James Peck details, citing Neier's claim that economic rights are undemocratic as well as the wider observation that the Reagan administration had no difficulty capitalizing on many human rights groups' anti-statism. ${ }^{15}$ Journalist Mark Ames points out the resemblance between Neier's view that economic rights impede the protection of negative rights (or more broadly "freedom") not only with Friedrich Hayek, but also with Social Darwinist William Graham Sumner:

As with Neier, William Graham Sumner argued that liberty has an inverse relationship to economic equality; according to Sumner, the more economic equality, the less liberty; whereas the greater the inequality in a society, the more liberty its individuals enjoy. It's the fundamental equation underlying all libertarian ideology and politics-a robber baron's ideology at heart. 316

\footnotetext{
314 Ibid, 63-64.

315 James Peck, Ideal Illusions : How the U.S. Government Co-opted Human Rights, 94, 95. ${ }^{116}$ Mark Ames, "The Big Sellout: How the ACLU and Human Rights Groups Quietly Exterminated Labor Rights," Naked Capitalism, June 2012, http://www.nakedcapitalism.com/2012/06/markames-the-lefts-big-sellout-how-the-aclu-and-human-rights-groups-quietly-exterminated-laborrights.html, accessed December 17th, 2015.
} 
Not only Sumner, but also Milton Friedman makes the same point in Capitalism and Freedom. ${ }^{17}$ Ames details previous initiatives taken by Neier-while head of the ACLU-against organized labor, as well as in favor of campaign financing as freedom of expression. In the first instance, Ames refers to William F. Buckley Jr.'s-a onetime board member of Amnesty International U.S.A.318-account of a conversation with Neier in which he expressed the intention of convincing others in the ACLU that the union shop violates civil liberties. ${ }^{319}$ The ACLU's support of Buckley's brother in Buckley vs. Valeo (and their subsequent amicus brief in support of Citizens United) is also cited by Ames, who makes a broader case that many human rights groups have been accomplices to the reduction of labor rights in the U.S.

Neier, an important figure at the ACLU, HRW, and subsequently at George Soros' Open Society Foundation thus appears to have a clearly well thought-out position against economic rights, as well as an antiquated conception of equality, all of which are consistent with economic inequality and injustice. Here "human rights," in the sociological sense, are hardly "helpless bystanders." As represented by Neier, the human rights movement has agency, but it also has power. Neier had described himself as the Secretary of State of the only private citizen in the world with his own foreign policy, George Soros. ${ }^{20}$ That is no "powerless companion." And yet, human rights, as conceived of by the field cannot offer any defense, not only to a society, but to individuals, against the anti-democratic

\footnotetext{
317 Milton Friedman, Capitalism and Freedom, (Chicago : University of Chicago Press, 2002), 5. ${ }^{18}$ Keys, Reclaiming American Virtue, 193.

319 Ames, "The Big Sellout."

320 Neier, 299.
} 
consequences of a decision like Citizens United. The human rights movement was free to set economic and social rights aside for ideological or methodological reasons, as defended by the current HRW head, Kenneth Roth, ${ }^{221}$ but it could not have failed to foresee that ignoring economic injustice, or worse still, attempting to scrub economic and social rights from the Universal Declaration, would leave those individuals whose rights it purports to defend, defenseless. As Neier claims that economic "issues" undermine political rights, so too does defending political rights to the detriment of economic rights cause them to be seen as issues of distributive justice to be gently adjudicated through elections with nearly unlimited campaign spending where the most vulnerable do not stand a chance to have their economic aspirations-if they even dare hold them-heard. The human rights movement was reckless, if not more, but it was also opportunistic, taking full advantage of the U.S. turn to human rights with the aim of "reclaiming American virtue.”22 It should be obvious that raising economic injustice at home as a human rights issue would not serve as the moral tonic that the Carter and Reagan administrations had in mind.

\section{(D) Schindler's Social Darwinism}

The rise of human rights as a triumphant project thanks to its streamlined focus on summum malum is intertwined with both the Holocaust memory boom that occurred at roughly the same period, as well as the creation of institutions of

\footnotetext{
${ }^{321}$ Kenneth Roth, "Defending Economic, Social and Cultural Rights: Practical Issues Faced by an International Human Rights Organization” Human Rights Quarterly, Vol. 26, No. 1 (Feb., 2004), pp. 63-73.

${ }^{222}$ See Barbara Keys, Reclaiming American Virtue: The Human Rights Revolution of the 1970 s
} 
international criminal law. As we have seen, inequality, neoliberalism, and economic injustice begin to hold sway at approximately the same time. The year 1993 is when the Holocaust Museum is inaugurated, with Elie Wiesel's dedication beseeching that something be done about Yugoslavia; just two months before, the first international criminal tribunal since Nuremberg and Tokyo is established by the United Nations Security Council. Returning briefly to Aryeh Neier, it is instructive to note that he claims to have initiated the call for criminal prosecutions in relation to "ethnic cleansing" in Bosnia, in July 1992. The ethnic character of the crimes being committed, according to Neier, were reminiscent of Nazi methods, thereby justifying the proposal of a Nuremberg type body.323

James Peck mentions that broad interest in Bosnia at about the same time "coincided with a blossoming of popular films, books, and academic programs and the opening of the Holocaust Memorial Museum in Washington."324 The culmination, writes Peter Novick, of the process of affixing the Holocaust to American culture was the 1993 release of Steven Spielberg's Schindler's List. 325 The film was not only a box office success, it received moral plaudits from Oprah Winfrey who announced "I'm a better person as a result of seeing Schindler's List," 326 and from President Clinton, who "implored" Americans to see the film. ${ }^{327}$ It also seemed to resonate politically, as special screenings of the film were

\footnotetext{
323 Neier, Taking Liberties, 230-231.

324 James Peck, Ideal Illusions: How the U.S. Government Co-Opted Human Rights (New York: Metropolitan Books, 2010), 231. 325 Novick, The Holocaust in American Life, 214. 326 Ibid.

${ }^{327}$ Joseph McBride, Steven Spielberg: A Biography (Second Edition) (Faber \& Faber, 2010), 435.
} 
organized for the leaders of France, Germany, Israel, Austria, and Poland. ${ }^{28}$ According to Spielberg's biographer, Schindler's List provided much the same emotional experience as the newly opened Holocaust Memorial and Museum.329 The experience of seeing the film is described by Novick as overwhelming, a confrontation with horror and grief that moved many-including himself-to tears. He adds, however, that "this leaves unresolved the question of why the eliciting of these responses from Americans is seen as so urgently an important task." 330

The film was not without its detractors, many finding the redemptive "feel good" plot unspeakably inappropriate, ${ }^{331}$ or others, such as Nobel Prize winner and Holocaust survivor Imre Kertész, denouncing the very idea of portraying human beings emerging from the camps healthy and unharmed as kitsch. Kitsch, too, for Kertész, is the representation of the Holocaust as a phenomenon that would be foreign to human nature. ${ }^{32}$ Alvin Rosenfeld registers some surprise that Schindler's List entirely reverses the empirical reality of the destruction of the European Jews, as developed by Raul Hilberg,333 from perpetrators, victims, then later in his research, bystanders, to the tragically statistical outliers of survivors and rescuers. 334 Given, as Rosenfeld observes, that the virtue of

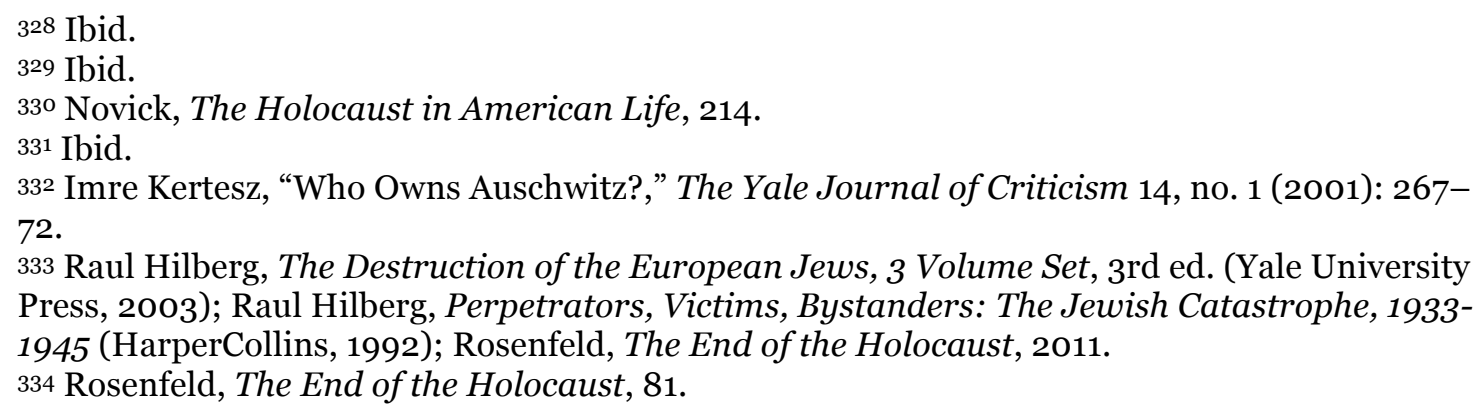


Schindler's List is that it may well be the introduction, or perhaps the sum total in some cases, of exposure to knowledge about the Holocaust, it is unfortunate that it distorts the truth about the general thrust of the killings during that period of history. Survivors were rare, and rarer still were the rescuers. It may be, however, that some degree of tolerance ought to be afforded to Hollywood treatments of historical events, and in any event, as Hilberg lamented, kitsch, distortion, manipulation, and even plagiarism are not unheard of in Holocaust scholarship. 335

As Kirby Farrell notes with respect to Schindler's List-as does Novick more generally in his attempt to grasp how and why the Holocaust rose to prominence when and where it did336-the film "recreates the past through present concerns." 337 Farrell then asks, point blank: "Given all the stories which could have been told about the Holocaust, why are we moved at this historical moment by an account of a factory boss saving people from death by making them slave laborers?" 338 He details-and the characters have aged prematurelythe handsome bonuses received by "heroic chairman Lee Iacocca," who days later announced the transfer of K-car production to Mexico; similarly Farrell recalls another film, Michael Moore's Roger \& Me and the destruction of Flint,

335 Hilberg, The Politics of Memory, 138-157.

$33^{6}$ Novick, The Holocaust in American Life, 3, citing, or rather relying on a misinterpretation and erroneous translation of French sociologist of collective memory Maurice Halbwachs. On the distortion of Halbwachs' contribution in American Memory Studies, see my "The Assassination of Maurice Halbwachs," forthcoming, Humanity.

337 Kirby Farrell, "The Economies of Schindler's List," Charles L. P. Silet, The Films of Steven Spielberg: Critical Essays (Scarecrow Press, 2002). 338 Ibid, 193. 
Michigan,339 without knowing then that the true dystopia of the automobile industry, or the calamitous state of Flint-declared a state of emergency in December 2015 due to important quantities of lead in the water340-actually lay ahead. While allowing, as surely he must, that the Nazi slave economy was more horrific than America in the 1990s, he notes a number of distressing social developments affecting the working class in "postindustrial America": falling wages, dissolving job security, erosion of retirement, and increased earnings inequality between CEOs and workers. He observes that anxiety about economic injustice has begun, just as Schindler's List is released, to bubble to the surface, citing articles published at the time. 341

Farrell makes parallels between the insane productivity of Nazi slave-labor factories-as then "superfluous labor" meant death and incentives to produce were accordingly and barbarically high-and the emerging business models of the 1990s, from total quality management (with its interchangeable workers), downsizing, management slogans such as "lean and mean," layoffs of older and less healthy workers to avoid paying benefits, and the export of jobs with the type of industrial production Spielberg depicts. Bartov and Kertesz have both, albeit the former calling it "subversive" and the latter calling it "kitsch," cautioned against the failure to see the Holocaust as something not foreign to us-"us" being the developed, industrialized world-as it is precisely a society like ours

\footnotetext{
339 Ibid.

340 All Things Considered, "A Return To Flint, Where The Mayor Has Declared A State Of Emergency," NPR.org, accessed December 20, 2015, http://www.npr.org/2015/12/19/460414818/a-return-to-flint-where-the-mayor-has-declared-astate-of-emergency.

${ }^{341}$ Farrell in Silet, The Films of Steven Spielberg, 200-201.
} 
that committed and can commit such a genocide. ${ }^{342}$ It is therefore not surprising that Farrell can detail these economic similarities (of degree), and the reader is left to determine how persuasive is the subtle suggestion that Hollywood wishes American workers or the unemployed to favorably compare their plight to doomed Jews facing certain death if not for the intercession of the Nazi party member and cheerful opportunist turned benevolent lifesaving entrepreneur. Such is the gratitude of the slave labor to Schindler for saving their livescontrast here with the famous March $27^{\text {th }}, 1941$ demonstration in Belgrade, opposing the authorities' alliance with the Nazis, where the slogan was "Bolje grob nego rob!," "Better grave than slave!"343-that their last industrial act in Schindler's factory is to manufacture a gold ring from their fillings to give to their benefactor.

There would probably be no possible restrained Marxist reading of that scene (or of that historical event), and none shall be attempted here. Another gesture the Shindlerjüden extend to the man who upon Nazi surrender may face capture for the war crime of exploiting slave labor, is a note describing his good works, and his successful deployment of many talents to save 1100 people, so that he might escape an eventual war crimes prosecution. One practicing law as a defense attorney at the time, when talk of prosecuting the Serbs dominated the news, could not help but notice that for all the Holocaust analogies driving the establishment of the newly-minted international criminal tribunal, the box office

\footnotetext{
342 Omer Bartov, "Chambers of Horror: Holocaust Museums in Israel and the United States," Israel Studies 2, no. 2 (1997), 74; Kertesz, "Who Owns Auschwitz?” 343 Wayne S. Vucinich, Jozo Tomasevich, Contemporary Yugoslavia: Twenty Years of Socialist Experiment (University of California Press, 1969), 54.
} 
hit and Oscar victor of the day told a story not just about rescue (in fairness, of course it did), but also about slavery, and paradoxically, impunity.

Farrell also successfully discusses the influence of Social Darwinism both in Nazi industrial production-and the effect, literally, of "survival of the fittest" on the lives of slave labor on an assembly line-as well as the broader embrace of eugenics in Nazi ideology.344 The discussion may well succeed because of its familiarity: certainly it is well grounded in the American history of economic ideas as a defense of capitalism as "natural law.”345 John Kenneth Galbraith's study of American attitudes "rooted in the poverty, inequality and economic peril of the past," 346 devotes what could seem a surprising amount of attention to Social Darwinism. He believes that it was in practice dealt crippling blows first by democracy, citing Barry Goldwater's 1964 rout, and by the modern corporationwhich by virtue of its "immortality," he mentions General Motors and General Electric-no longer engages in the kind of struggle Herbert Spencer and Sumner had in mind between, say, individual entrepreneurs. 347 Corporate "immortality" is of course one of the most compelling objections to the Citizens United decision regarding corporate personhood; but there are instances when the faith in everlasting corporate life is challenged. Thus, Vice-President Biden, on a Labor Day stump speech in Detroit during the 2012 election campaign summed up the

\footnotetext{
344 Farrell in Silet, The Films of Steven Spielberg, 202.

345 John D. Rockefeller described economic Darwinism as "the working-out of a law of nature and a law of God," in Richard Hofstadter, Social Darwinism in American Thought (Boston : Beacon Press, 1995), 45. 346 John Kenneth Galbraith, The Affluent Society (Houghton Mifflin Harcourt, 1998), 2. 347 Ibid, 52.
} 
success of the Obama administration: "Osama bin Laden is dead and General Motors is alive." 348

Galbraith sees Social Darwinism's improbable survival in two areas, the first being in the realm "of attitudes which American brought into the age of affluence,"349 and the second being an attribution of "a special mystique to the market." 350 Where general attitudes are concerned, Americans could think that here, more than anywhere, the ordinary person had equal chances of success. Yet, they also had to face the fact that economic life was a mortal struggle, that a chance of winning also meant a chance of losing, that the consequences of losshunger, privation and death-must be accepted. He adds:

Poverty and insecurity became inherent in the economic life of even the most favored country. So, of course, did inequality, and this was firmly sanctified by the fact that those who enjoyed it were better. ${ }^{31}$

Where the market is concerned, Galbraith contends that its idealization broadened its own claims to the detriment of "social measures designed to rescue the individual from the privation or to protect him from the hazards of economic life." 352 This resembles the attitude towards economic and social rights held by Aryeh Neier, as well as the current state of enforceable protection of such rights today.

348 Rodney Hawkins CBS News September 3, 2012, "Biden: We Are Better Off, 'Bin Laden Is Dead and General Motors Is Alive,"” accessed December 21, 2015,

http://www.cbsnews.com/news/biden-we-are-better-off-bin-laden-is-dead-and-general-motorsis-alive/.

349 Galbraith, The Affluent Society, 52.

350 Ibid, 53.

351 Ibid.

352 Ibid. 
For the sake of argument, let us assume that Neier is correct and that economic rights diminish the protection of political rights. 353 It should follow then that the neglect of economic rights would have served to strengthen those most important civil and political rights, such as the core, crucial rights to freedom of expression, the presumption of innocence, or the right to an independent, impartial trial.

Defendants at the ICTY and ICTR have not made broad demands for anything like economic redress, much less a socialist utopia. They have merely asserted their most liberal "bourgeois" fair trial rights, and sadly have had to denounce the violation of what Neier would argue are cornerstone human rights. Yet he himself when discussing Milosevic's court case takes the tone and tenor of the prosecutor, having perhaps forgotten along the way his four decade long career devoted to protecting the human rights of individuals. 354 As I have detailed elsewhere, 355 in the context of highly politicized trials, those basic fair trial rights defended by the human rights field (be it NGOs, academics, or governments) to the detriment of economic rights, have not fared as well as what the new institutions of international criminal law have claimed.

\footnotetext{
353 Neier, Taking Liberties, xxx.

354 Ibid, 349.

355 See Tiphaine Dickson and Aleksandar Jokic, Targets of International Justice: Yugoslavia and Rwanda First in Focus (forthcoming); Tiphaine Dickson and Aleksandar Jokic, "Hear No Evil, See No Evil, Speak No Evil: The Unsightly Milosevic Case," International Journal for the Semiotics of Law 19 (4) (2006): 355-387; Tiphaine Dickson, "De l'invisible attentat aux faux experts: le combat des avocats de la defense au Tribunal penal international pour le Rwanda," in Charles Onana (ed), Silence sur un attentat: le scandale du genocide rwandais, (Paris: Editions Duboiris, 2005), 83-100.
} 
Defendants' freedom of expression, their right to a public, independent and impartial trial, due process, as well as the presumption of innocence have all been violated by these bodies since their inception in the 1990s. Thus scuttling economic rights may have been beneficial for the human rights organizations themselves, but setting them aside did not make fair trial rights hardier in exchange. Indeed, not only did the most influential human rights NGOs demonstrate hostility towards the economic rights that might have, if only discursively or perhaps culturally, opposed the rising tide-turned-tsunami of neoliberal inequality-already apparent in 1977 for Lindblom just as rights became the Western buzzword-but those same organizations abruptly turned prosecutorial when ad hoc courts were created, thereby undercutting those few remaining rights of relevance to accused persons before international courts. Blind faith in the markets and the uncritical idealism of human rights were reckless and opportunistic where the basic economic well-being and decent conditions of life of people was concerned. Not only have they ignored, and contributed to rendering illusory or dangerously populist those very economic safeguards agreed upon in the drafting of the Universal Declaration of Human Rights, but in their desire for proximity to power, have ultimately cost defendants those very rights they claimed they were most keen to preserve. 


\section{Essay 3: "The World's Court of Justice": A Historiography of War Crimes Prosecutions}

"Presque toute l'histoire n'est donc qu'une longue suite d'atrocités inutiles" 356 "The History of the world is the world's court of justice."357 "History is a pack of tricks we play on the dead." 358

The Gavel of History

To say that the influence of history on war crimes trials and international criminal law is significant would be an understatement. The discipline of history participates in the establishment of a narrative that international courts (and their political proponents) consider as being true; this truth in turn becomes, in the highly charged context of, for example, a genocide trial, the historical account that must be proven as a matter of law. The idea of (writing) history becomes one of the objectives of the court, and some judges, not content to note the historical nature of their functions adopt, in addition, the mantle of historians.359 But contrary to those they emulate, they seek an account not subject to appeal. Historical events and historic legal precedents from the mid-twentieth century lend solemnity and purpose by analogy. After all, the judges who preceded them

${ }^{356}$ Voltaire, Essai sur l'histoire générale et sur l'esprit et les moeurs des nations, (Cramer, 1757), 24.

357 Karl Löwith, Meaning in History (1949) cited in Carlo Ginzburg, "Checking the Evidence: The Judge and the Historian," in Questions of Evidence: Proof Practice and Persuation Across the Disciplines, James Chandler, Arnold I. Davidson, and Harry Harootian, eds. (Chicago: University of Chicago Press, 1994), 291.

358 Words of Voltaire cited in Judith Shklar, "Learning Without Knowing," Political Thought and Political Thinkers, Stanley Hoffmann, ed., (Chicago: University of Chicago Press, 1998), 117. 359 The International Criminal Tribunal for the Former Yugoslavia's website, in its "About Us" section, makes this plain: "The Tribunal has contributed to an indisputable historical record, combating denial and helping communities come to terms with their recent history." http://www.icty.org/sections/AbouttheICTY, accessed April $7^{\text {th }}, 2015$. 
at Nuremberg, at least in France, have their words enshrined in legislation that prohibits contesting (“contester") the existence of crimes against humanity as defined by the Nuremberg Charter committed by organizations deemed criminal or by individuals found guilty by French or international tribunals. ${ }^{360}$ Members of the French Commission on Constitutional Law, the commission being a legislative committee, have argued that this provision of criminal law can be extended to questioning (or "contesting") the existence of crimes against humanity as held by judges of the ad hoc International Criminal Tribunal for the Former Yugoslavia and the International Criminal Tribunal for Rwanda. ${ }^{361}$ It should not come as a surprise that a number of reputable historians ${ }^{362}$ have publicly objected to this law, and asked for its repeal, among them the tireless opponent of Holocaust denial and son of two parents killed in Auschwitz, Pierre Vidal-Naquet. “History is not a legal object," Vidal-Naquet wrote in an op-ed published in Libération. "In a free state, it is not the province of Parliament or the courts to define historical truth. State policy, even when animated with the best intentions, is not the policy of history." 363

And so a historian protests the enactment of a criminal law that protects the history written by judges in international criminal cases-at times with the help

\footnotetext{
360 "Loi Gayssot," Law No. 90-615 of July 13, 1990, J.O., July 14, 1990, p. 8333.

${ }^{361}$ Assemblée Nationale, No. 3074, "Rapport fait au nom de la Commission des lois constitutionnelles, de la législation et de l'administration générale de la république sur la proposition de loi ( $\mathrm{n}^{\circ}$ 3030) de m. Didier Migaud et plusieurs de ses collègues, complétant la Loi $\mathrm{n}^{\circ}$ 2001-70 du 29 janvier 2001 relative à la reconnaissance du génocide arménien de 1915, Par M. Christophe Masse, Député," May $15^{\text {th }}, 2006,15$.

${ }^{362}$ See René Rémond, "L’histoire et la loi," Études, June 2006.

363 My translation. "L'histoire n'est pas un objet juridique. Dans un État libre, il n'appartient ni au Parlement ni à l'autorité judiciaire de définir la vérité historique. La politique de l'État, même animée des meilleures intentions, n'est pas la politique de l'histoire.” Pierre Vidal-Naquet, December 13, 2005, Libération.
} 
of expert historians-from the scrutiny of historians. This essay examines how we got there.

\section{Law in History}

Law and history have long been interrelated. Historians have employed law's artifacts-judgments, transcripts, letters exchanged in the margins of trials, 364 accounts of trials-to tell stories about politics, society, institutions, and philosophy. From the numerous conflicting accounts of the trial of Socrates to historical scholarship on the witchcraft trials of the Inquisition, law's manifestation through sources offers useful evidence for the work of the historian. Legal proceedings leave precious archival records for historians to mine. 365 But this observation is trivial if the purpose for which historians employ archival evidence generated by law is ignored. The Annales school366-named after the 1929 French journal, Annales d'histoire économique et socialeintroduced a new approach to social history, borrowing from Emile Durkheim's contribution to the sociological theory of collective unconscious, as well as from the structuralist theories developed in anthropology. ${ }^{367}$ It is with these methods

\footnotetext{
364 Michael Grossberg "How to Tell Law Stories," Law and Social Inquiry, 1998, Vol. 23 (2)(Spring, 1998), 459-470, 365 Martha Howell and Walter Prevenier, From Reliable Sources: an Introduction to Historical Methods, (Ithaca: Cornell University Press, 2001), 34. 366 Howell and Prevenier, From Reliable Sources, 110; Ginzburg, "Checking the Evidence: The Judge and the Historian," in Questions of Evidence: Proof Practice and Persuation Across the Disciplines 293 ${ }^{367}$ Collective consciousness is theorized by Durkheim as a shared set of beliefs and understanding of social norms among given social groups. These group beliefs can usefully be studied over time by historians. Structuralist anthropology provided a theory that could delve into the way human society assigned identities, functions, and roles. Notions such as gender, space, time, life and
} 
and approaches that historians of this school studied social units such as women, the poor, marginal elements of society as well as the ideas creating the boundaries and values of these elements in their historical context. 368

Inquisition records provided evidentiary foundation for the exploration of themes well beyond the narrow scope of the trials themselves; Emmanuel Le Roy Ladurie reconstituted the complex social relations of a $14^{\text {th }}$ century French town on the basis of Jacques Fournier's Inquisition records of the investigation of 94 people accused of heresy in Montaillou, setting the records against the broader economic, social and political context of the time. ${ }^{369}$ Carlo Ginzburg's The Cheese and the Worms, ${ }^{370}$ as well as The Night Battles, examine society, beliefs, and cosmology by exploring the gaps created by misunderstandings and distortions contained in Italian Inquisition records. ${ }^{371}$ This work disproved the pessimism of many historians regarding the possibility of reconstructing the lives of average individuals, and even more so, the underprivileged of the distant past, as evidence did not exist in a sufficient amount to document their daily habits and social relations. ${ }^{372}$ The law proved critical in permitting this approach to emerge, as Ginzburg puts it, since "the richest (not to say the only available) evidence for these entries has been provided, either directly or indirectly, by court records

\footnotetext{
death are elements of social structure, both founding it as well as being produced by it. Howell and Prevenier, From Reliable Sources, 110-111.

368 Ibid.

369 Ibid., 111.

${ }^{370}$ Carlo Ginzburg, The Cheese and the Worms: The Cosmos of a Sixteenth-Century Miller, trans. John and Anne Tedeschi, (New York, 1982).

371 Arnold. I. Davidson, "Ginzburg and the Renewal of Historiography," in Questions of Evidence, 320.

372 Ginzburg, "Checking the Evidence: The Judge and the Historian," 300.
} 
from distance places and times: fourteenth- or sixteenth-century France, seventeenth-century Italy or China.”373

But more crucially than the issue of availability, as important as it is, the fact is that history and law share some core methodological affinities. History, originally conceived as a practice on the intersection of medicine and rhetoric, 374 reflects not only tools of legal reasoning and argument, but also the evaluation and careful weighing of evidence375. History is, however, the self-conscious reconstitution of that evidence into a coherent, honest, yet nonetheless subjective narrative. ${ }^{36}$ Peter Brooks writes, regarding histories of law, that: “How stories are told, listened to, received, interpreted-how they are made operative, enacted-these are issues by no means marginal to the law nor exclusive to theory; rather they are part of law's daily living reality." 377 What this means with respect to history is that good history is a story well told, conveying an illusion of reality ${ }^{378}$ but it is not-and surely cannot be tolerated as-a merely fictional exercise. Evidence matters. But what can be reconstructed is a storyscrupulously respecting the integrity and authenticity of evidence-that borrows from the literary genre, allowing the historian to consider matters that had been

373 Id., and c.f. Ginzburg, "The Inquisitor as Anthropologist," Clues, Myths and the Historical Method, trans. John and Ann Tedeschi (Baltimore, 1989) 158-159.

374 Ginzburg, "Checking the Evidence: The Judge and the Historian," 290-291.

375 Ibid., 290.

376 Howell and Prevenier, 20.

377 Peter Brooks, "The Law as Narrative and Rhetoric," in Peter Brooks and Paul Gewirtz, Law Stories, Narrative and Rhetoric in the Law. (New Haven, Conn.: Yale University Press, 1996). 378 Ginzburg, The Judge and the Historian: Marginal Notes on a Late-Twentieth-Century Miscarriage of Justice, trans. Antony Shugaar, (London: Verso, 2002) 12. 
considered irrelevant (such as peasants and "witches") or for which the evidence was scarce. 379

Thus law and history overlap, but they are not interchangeable. Earlier historiography emphasized persuasion, at the expense of the production of evidence, the latter being reserved to antiquarians. ${ }^{800}$ In the eighteenth century, the practice of the historian considering evidence and "testimony" emerged; and so, too, did the practice of the historian assuming the role of a judge. ${ }^{81}$ Ginzburg shows how profoundly the influence of the judicial temper and function affected historiography at this time: first, Hegel's grand pronouncements, in his philosophy of history, of the "Weltgericht," "verdict of the world"-which also means "Last Judgment,"-against which Nietzsche railed furiously in his Uses and Abuses of History ${ }^{382}$ - then Lord Acton's characterization of history as a legitimate tribunal dispensing universal truth. ${ }^{383}$ But this approach oriented historiography to the examination of great events, leaving aside the type of social relations later captured by the Annales school-paradoxically, perhaps, thanks to the assistance of sources generated by the legal process. It is thus that social historians chose to understand rather than to judge. ${ }^{884}$

The judicial process and the law, writes Ginzburg, travel along the same road in the initial stages of their respective purposes, both, in particular, paying

\footnotetext{
379 Ginzburg, "Checking the Evidence: The Judge and the Historian," 297. 380 Ginzburg, The Judge and the Historian: Marginal Notes on a Late-Twentieth-Century Miscarriage of Justice, 12-13.

381 Ibid.

382 Judith Shklar, "Learning Without Knowing," Political Thought and Political Thinkers, 115. 383 Ginzburg, "Checking the Evidence: The Judge and the Historian," 292.

384 Ibid. 293.
} 
careful attention to facts and evidence; but they must necessarily diverge at one point. Both justice and history suffer from conflation of purposes, and indeed, in Ginzburg's apt formulation, "whoever attempts to reduce the historian to a judge simplifies and impoverishes historiographical consciousness; but whoever attempts to reduce the judge to historian irredeemably pollutes the exercise of justice. $385 "$

\section{History in Law}

"The remote past," wrote Judith Shklar, regarding the charge of waging aggressive war in Nuremberg, "cannot be legally tried, and the remote future cannot be controlled." 386 In Legalism, Shklar sharply distinguished the legal and historical approaches to events on the basis of different methodological commitments to causality 387 . Where historians and jurists could agree, she argued, was on simple matters of causality such as John Wilkes Booth being the cause of Abraham Lincoln's death. But historians, though their discipline provides them with professionally understood and accepted cut-off points in time, nonetheless explore vast swaths of social and economic interrelations over time and space. This, she argues, makes history uniquely ill-suited to examining charges, brought in the judicial sphere, such as that of waging aggressive war,

385 Ginzburg, The Judge and the Historian: Marginal Notes on a Late-Twentieth-Century Miscarriage of Justice, 118. ${ }^{386}$ Judith Shklar, Legalism, (Cambridge MA: Harvard University Press, 1964) 171.

387 Causality, here, refers to the historian's interest in change, and the examination of phenomena, events, or antecedents that may have played a role in the change. Complex events have complex antecedents; this requires historians to take account of that complexity when exploring a causal explanation. Howell and Prevenier, From Reliable Sources, 128. 
since the prosecution of such an offence (and inevitably its defense) would introduce a discussion of the causes of the war. This exploration can be taken up by the historian, but it embraces far more than what a trial requires and indeed allows. ${ }^{388}$ Much of the contemporary scholarship on the role of history in the legal process, however, has not been as skeptical as Shklar's.

In the heady post-cold war years Shklar's work-Legalism and "The Liberalism of Fear," an essay-were in fact posthumously employed to variously promote the idea that war crimes trials had always been established by liberal democracies, 389 or to restore, urgently, faith in liberalism-paradoxically lost after it had ostensibly triumphed against the ideas of Marx-by highlighting terror and fear abroad, thus creating vocations of heroism for American rebels without a cause. ${ }^{390}$ Standard accounts now repeat that the nineteen-nineties were years where atrocities were unleashed while the West stood by; 391 in this narrative, those who did act (usually with the pen, or more frequently the laptop of the foreign correspondent) were fighting the tide of stubborn inaction. The claim seems curious, as not one, but two, ad hoc international criminal tribunals were established by the Security Council of the United Nations before the end of 1994. ${ }^{392}$ This is worthy of mention as the creation of these bodies is a legitimate object of study for history; but the type of history that has been produced to

\footnotetext{
388Shklar, Legalism., 195-197.

${ }^{389}$ See Gary J. Bass, Stay the Hand of Vengeance: the Politics of War Crimes Tribunals, (Princeton: Princeton University Press, 2000), 20.

390 Corey Robin, Fear: The History of a Political Idea, (New York: Oxford University Press, 2004) 145-147.

${ }^{391}$ Samantha Power, A Problem From Hell: America and the Age of Genocide, (New York: Perrenial, 2003).

392 Report of the Secretary-General Pursuant to Paragraph 2 of the Security Council Resolution 808 (1993), UN Doc S/25704, 3 May 1993; SC Res. 955, 8 November, 1994.
} 
account for it, bears striking resemblance to the biographies of great men-one can think here of Samantha Power's lionization of Raphaël Lemkin and William Proxmire393-or to the early historiography advocating Christianity.394 The contemporary cause is the fight against atrocities and its urgent and graphic nature justify the adoption of a historiographical genre better suited to advocacy than to understanding. 395

\section{A Brief History of the ICTY}

It is impossible to assess the quality of ad hoc tribunals writing of history without reference to these bodies' origins and purposes, as well as to the specific historical conditions that colored the first post cold war decade.

The ICTY was created by the Security Council of the United Nations in 1993, after both decades of inaction following Nuremberg and Tokyo, as well as decades spent fruitlessly laboring at drafting a code of offenses. 396 The prosecution of crimes against the peace-described by the Nuremberg judgment as the "supreme international crime"-was relegated to a form of protest in the cold war years, as with Bertrand Russell and Jean-Paul Sartre's "popular" tribunals judging French and American actions in Vietnam. ${ }^{297}$ After the first Gulf War, both Margaret Thatcher and George H.W. Bush called for the creation of a

\footnotetext{
393 Samantha Power, A Problem From Hell: America and the Age of Genocide. 394 Howell and Prevenier, From Reliable Sources, 5. Incorporated, 2004).

397 Frédéric Mégret, "The Politics of International Criminal Justice," European Journal of International Law 13, no. 5 (2002): 1261-84.
} 
special UN court to try "Iraqi war criminals," 398 an initiative that was no more successful than the initiative of the (then twelve) European Community states to petition United Nations Secretary General Javier Perez de Cuellar to "examine the personal responsibility" of Iraqi leaders for acts of genocide.399 Western support for Iraq against Iran, including arming in conventional as well as chemical weapons was a more recent memory then, leading some to speculate that such a trial might have proven too politically perilous to attempt. 400

In June 1991, Slovenia seceded from Yugoslavia. The republics of Croatia and Bosnia and Herzegovina followed suit. Fighting erupted in the latter two territories, prompting a United Nations arms embargo, 401 followed by the deployment of European peacekeepers, assistance in the delivery of humanitarian aid, as well as the imposition of economic sanctions. ${ }^{402}$ The media's increased coverage of the war, and its framing of the conflict as a one-sided infliction of barbarity (by the Serbs) against defenseless civilians ${ }^{403}$ created the impression that not only solutions short of armed intervention could do nothing to alleviate the humanitarian situation, but that a judicial process ought to be established, as

\footnotetext{
398 Cassesse, Antonio, The Path the The Hague: Selected Documents on the Origins of the ICTY (The Hague: United Nations, 1996), 9; Bass, Gary Jonathan, Stay the Hand of Vengeance: The Politics of War Crimes Tribunals (Princeton, N.J.: Princeton University Press, 2000), 210; Hazan, Pierre, Justice in a Time of War, (College Station: Texas A \& M University Press: 2004) 9; U.S. Department of State, Dispatch, 12 November 1990.

399 Pierre Hazan and James Thomas Snyder, Justice in a Time of War: The True Story Behind the International Criminal Tribunal for the Former Yugoslavia, trans. James Thomas Snyder (Texas A\&M University Press, 2004), 10. 400 Ibid.

${ }^{401}$ Samantha Power, A Problem from Hell: America and the Age of Genocide (Basic Books, 2002), 249. 402 Ibid., 251. 403 Diana Johnstone, Fools' Crusade: Yugoslavia, NATO, and Western Delusions (New York: Monthly Review Press, 2002) 65-77.
} 
a matter of urgency, to show international resolve. 404

Historical analysis suggests that the run-up to what can be called the judiciarization of the conflict was not solely driven by idealism, compassion, or pathos. The conflict, before it was framed as a narrative of atrocities, had been viewed by the Bush administration as a matter for Europeans to demonstrate their nascent strength and authority. "Yugoslavia," wrote Secretary of State James Baker, “was as good a first test as any.”405 Moreover, the Bush administration had overcome its "Vietnam complex" in Iraq, and wished to focus on domestic and economic issues. ${ }^{406}$ Europeans viewed matters differently, emphasizing instead that the fact that they had-in contrast to the Americanspeacekeeping troops on the ground, which justified preferring diplomatic attempts to broker peace. Thus European concern-while mischaracterized as simple weakness and ineffectuality407-focused on negotiated settlement for the safety of European troops and for an ultimate resolution of the conflict. 408

In August 1992, however, media reports of concentration camps and images suggesting conditions reminiscent of Nazi places of detention during the

\footnotetext{
404 Power, A Problem from Hell 247-249; Gary Jonathan Bass, Stay the Hand of Vengeance: The Politics of War Crimes Tribunals (Princeton, N.J.: Princeton University Press, 2000) 207-214; Hazan and Snyder, Justice in a Time of War, 11-25; Congressional Research Service, Bosnia War Crimes: The International Criminal Tribunal for the Former Yugoslavia and U.S. Policy, 1996, updated 1998. .

405 Power, A Problem from Hell, 259; James Addison Baker, The Politics of Diplomacy:

Revolution, War, and Peace, 1989-1992 (New York: Putnam, 1995), 637.

406 Power, A Problem from Hell, 251.

407 Ibid., 259.

408 Hazan and Snyder, Justice in a Time of War, 10-11.
} 
Holocaust ${ }^{409}$ refocused the issue of the Yugoslav conflict significantly. Imagery and the emergence of a concentration camp narrative were central in what could be called (borrowing a chapter subheading from Samantha Power's A Problem From Hell) a successful deployment of “advocacy and analogy." 410 Yugoslavia was no longer a civil war somewhere in "Eastern Europe" (as it was frequently misreported), but a repetition of unmentionable crimes in the midst of Europe in the waning days of the twentieth century.

In the U.S., the shift coincided with a presidential election; then candidate William Jefferson Clinton attacked George H. W. Bush's inaction, promising armed intervention against the Serbs who were committing, he contended, genocide, further calling for perpetrators to be brought to justice. ${ }^{411}$ Clinton's eventual election to the presidency tempered his interventionist ardors, after Secretary of State Warren Christopher found little in the way of European enthusiasm to put peacekeepers at risk. ${ }^{412}$ The balance in favor of a judicial rather than a military or diplomatic approach was tipped heavily by an unexpected speech by Secretary of State Lawrence Eagleburger in Geneva at an international conference to support the negotiation efforts led by Cyrus Vance and Sir David Owen (known as the Vance-Owen plan) in the waning days of the Bush administration. Eagleburger called for the prosecution of Slobodan Milosevic and

409 Power, A Problem from Hell, 269; Hazan and Snyder, Justice in a Time of War 12-13; Johnstone, Fools' Crusade, 65.

${ }^{410}$ Holocaust analogies are of course not unproblematic in international relations. See Michael C. Desch (January-March 2006). "The Myth of Abandonment: The Use and Abuse of the Holocaust Analogy," Security Studies, Vol. 15, no. 1, p. 106. ${ }^{411}$ Power, A Problem from Hell, 274; Bass, Stay the Hand of Vengeance, 214.

412 Bass, Stay the Hand of Vengeance, 214. 
others, much to the chagrin of the European and British delegates who saw the outburst as definitively scuttling peace prospects. ${ }^{413}$ French diplomats expressed their exasperation, claiming that they were being employed as troops at the bidding of the Germans and Austrians (whose early recognition of Croatia had contributed to fanning the flames of war, but whose World War II actions, to employ a euphemism, prevented them from intervening themselves), as the Americans staked "out the moral high ground to avoid getting wet while we take all the hits in Bosnia." 414 Eagleburger had forced the hand of his successor, perhaps conveniently, to commit to the establishment of a war crimes trial-in lieu, as some have argued 415 of what at the time was the more complicated, risky, and internationally divisive policy of intervention.

French foreign minister Roland Dumas had been one of the early proponents of a war crimes prosecution, though his advocacy had left French President François Mitterrand cool until the French learned that the Italians were preparing a proposal for a tribunal.416 In January 1993, President Mitterrand publicly expressed his support for a war crimes prosecution days before President-elect Clinton was to be sworn into office. The following weeks, the two states engaged in what Pierre Hazan has described as "an opportunistic steeplechase" to circulate the final draft for an ad hoc court at the United Nations

\footnotetext{
413 Hazan and Snyder, Justice in a Time of War, 20-21.

414 Ibid., 33.

415 Bass, Stay the Hand of Vengeance, 215; Hazan and Snyder, Justice in a Time of War, 22;

Kenneth Anderson, "The Rise of International Criminal Law: Intended and Unintended Consequences," European Journal of International Law 20, no. 2 (April 1, 2009): 331-58, 334; Mark Mazower, Governing the World: The History of an Idea (Penguin Press HC, The, 2012), 397.

${ }^{416}$ Hazan and Snyder, Justice in a Time of War, 34.
} 


\section{Security Council.417}

The ICTY was established by the Security Council without opposition, despite concerns expressed by China, Venezuela, and Brazil. ${ }^{418}$ China followed its interests, whether that was seeking most favored nation status with the US, or responding to French delegation entreaties that they ought not be seen to be siding with the "butchers" if they wanted to increase their international standing (accounts from the American perspective are similar).419 The cold war rival, Russia, was in the process of privatization and liberalization; moreover, President Yeltsin, embattled and struggling with internal problems, was seeking U.S. political and economic support.420

Thus on February 22 ${ }^{\text {nd }}, 1993$, the Security Council passed Resolution 808, creating a Tribunal for the "prosecution of persons responsible for serious violations of international humanitarian law committed in the territory of the former Yugoslavia since 1991.”

This institution, a "law-like body" 421 established on the legal basis of the Security Council's power over international peace and security, and more specifically its ability to create "subsidiary organs as it deems necessary for the

417 Ibid., 36.

418 Ibid., 62.

419 Ibid. 37; Michael P Scharf, Balkan Justice: The Story behind the First International War Crimes Trial since Nuremberg (Durham, N.C.: Carolina Academic Press, 1997), 62. ${ }^{420}$ Hazan and Snyder, Justice in a Time of War, 37. ${ }^{421}$ Judith Shklar, Legalism: Law, Morals, and Political Trials (Harvard University Press, 1964), 156. 
performance of its functions" 422 is a creature of politics, specifically, as explained by Secretary-General Boutros-Ghali, as a remedy to a threat to international peace and security through the unprecedented use, by the United Nations, of a body to prosecute individuals (and not member states) for war crimes ${ }^{423}$ The tribunal's title indicates that it prosecutes "persons responsible," and the legal history of the ICTY's approach to modes of responsibility certainly indicates that this infelicitous formulation was taken seriously.

The brief historical sketch of the court's emergence stresses the importance of power, and interests in its establishment. The idea of the virtuous liberal (read American) war crimes court, to be judged by history, and that would, if it failed to treat a defeated enemy fairly, put a poisoned chalice to its own lips, 424 has by all accounts failed to materialize. An oddly disincarnated "justice cascade" has entrenched humanitarian norms in the UN system to be sure, but those continue to be unenforceable against the US (as well as China and Russia). 425

\section{Trying History}

It may be that the role of history in war crimes prosecutions is situated somewhere between judging and understanding. Richard Wilson undertakes the rebuttal of a trio of objections against the use of history in war crimes

\footnotetext{
422 Boutros Boutros-Ghali, Report of the Secretary-General Pursuant to Paragraph 2 of Security Council Resolution 808 (1993), (S/25704), par. 19.

423 Ibid., par. 10.

424 Nicolas J. S. Davies, Blood on Our Hands: The American Invasion and Destruction of Iraq (Nimble Books LLC, 2010), vi-vii.

425 Mazower, Governing the World, 399-401.
} 
prosecutions: that it is harmful to due process, that it is inconsistent with the legal approach, and that it generates "boring" history. ${ }^{426}$ Wilson begins from the questionable premise that the "standard" view is that history ought not play a role in the law governing atrocities, which can hardly be said to reflect the conventional scholarly, social, or even institutional wisdom on this point.

Starting with the public position of the International Criminal Tribunal for the Former Yugoslavia, as set out by their outreach program (a responsibility of the Registrar, one of the three organs of the Tribunal), a radical embrace of history, as well as of a sense of historical mission and accomplishment is immediately apparent:

The Tribunal has established beyond a reasonable doubt crucial facts related to crimes committed in the former Yugoslavia. In doing so, the Tribunal's judges have carefully reviewed testimonies of eyewitnesses, survivors and perpetrators, forensic data and often previously unseen documentary and video evidence. The Tribunal's judgements have contributed to creating a historical record, combatting denial and preventing attempts at revisionism and provided the basis for future transitional justice initiatives in the region.

As the work of the ICTY progresses, important elements of a historical record of the conflicts in the former Yugoslavia in the 1990s have emerged. The ICTY has established crucial facts about crimes, once subject to dispute, beyond a reasonable doubt. ${ }^{427}$

The pronouncement, by a Security Council body tasked to hold trials against individuals, that certain historical matters are now no longer subject to dispute is perplexing. Wilson, however, expresses the view that international tribunals, and

426 Richard Wilson, "Judging History: The Historical Record of the International Criminal Tribunal for the Former Yugoslavia," 2005, Human Rights Quarterly 27 (3) 908.

427 <http://www.icty.org/sid/324\# establishing> (last accessed December 7, 2015). 
in particular the ICTY, have overcome the main obstacles posed by previous courts, by virtue of their international nature. Part of the problem is that Wilson considers only objections to French proceedings against Paul Touvier, and Hannah Arendt's critique of the Eichmann trial; but obviously international courts are not a single nation-state exploiting a criminal trial for the purposes of restoring moral credibility as in the case of France or building a national identity as in the case of Israel. ${ }^{228}$ It thus says very little to point to international courts as not tributary of the idiosyncratic goals of particular states if that is to mean that such international status can guarantee fair trial and due process rights, or indeed that history has not been abused or potentially distorted. It hardly makes a difference from the due process standpoint that the Security Council is employing an international tribunal to write history instead of a nation state: the problems inherent in court-written history remain just the same. "A trial at the ICTY" writes Patricia Wald, former judge at the ICTY and quoted by Wilson, "is usually more akin to documenting an episode or even an era of national or ethnic conflict rather than proving a single discrete incident."429 Is Wald not describing a practice beyond that of the prosecution of individuals, more akin to Shklar's

\footnotetext{
428 Wilson refers to two well-known objections to court-written history: the first is Hannah Arendt's assessment that the Eichmann trial had been instrumentalized by the Israeli government to write a broad, sweeping history of anti-Semitism instead of concentrating on the criminal matter at hand and guaranteeing due process for the accused. Hannah Arendt, Eichmann In Jerusalem: A Report On The Banality Of Evil 253 (Rev. \& Enlarged ed., 1964), 19. Tzvetan Todorov, in turn, deplored that the French trials of Paul Touvier and Klaus Barbie engaged in forays into World War II history and questions of French national identity, rather than applying the law in an equitable way: "The Touvier Affair," in Memory, The Holocaust And French Justice: The Bousquet And Touvier Affairs (Richard J. Golsan ed., 1996) 120.

429 Patricia M. Wald, "To Establish Incredible Events by Credible Evidence": The Use of Affidavit Testimony in Yugoslav War Crimes Tribunal Proceedings," 42 Harvard International Law Journal 535, 536-37 (2001) cited in Wilson, "Judging History: The Historical Record of the International Criminal Tribunal for the Former Yugoslavia," 923.
} 
concerns regarding the historians' broader views of causality, and can it be blithely assumed that this will have no impact on the due process rights of an individual charged with specific criminal offenses?

In the end, Wilson does not meaningfully address the due process objections that emerge when war crimes prosecutions employ courts to write history; instead, he devotes considerable space to praise the quality of the history written by the ICTY, noting that the court's first judgment, in the case of Prosecutor v. Tadic, 430 restates the history of Yugoslavia (and its constituent parts, before the creation of the Socialist Federal Republic of Yugoslavia) from the fourth century to the armed conflicts justifying the establishment of the tribunal in 1993, as it was presented by the Prosecution's expert, military historian James Gow. ${ }^{41}$ Wilson then summarizes the sixty-nine pages that the Tadic judgment devotes to history even before addressing the indictment, and approvingly cites another prosecution expert witness, historian Robert Donia, who in his own published account of his role as a prosecution expert in another case, 432 wrote that " $\mathrm{t}] \mathrm{h}$ ese chambers have produced histories that are not only credible and readable, but indispensable to understand the origins and course of the 1990 conflicts in the former Yugoslavia."

430 Prosecutor v. Tadic; (Case No. IT-94-1-T), Judgment of Trial Chamber, 7 May 1997 ${ }^{431}$ Wilson, "Judging History: The Historical Record of the International Criminal Tribunal for the Former Yugoslavia," 927: "The history up to World War I is taken entirely from Gow's testimony and significant elements of subsequent history as well, including the role of President Tito in suppressing nationalist tensions, the significance of the 1974 Yugoslav Constitution, and finally the organization and ethnic composition of the Yugoslav People's Army in the 1980s and early 1990s", citing the Tadic Judgment at 9ף 56-79, 108-14.

432 Robert Donia, "Encountering the Past: History at the Yugoslav War Crimes Tribunal," Journal of International Institute 2 (2004), 11. 
The Tribunal judges, though writing a history spanning centuries on the basis of a single testimony (with the exception of a relatively narrow point about worker self-management offered by anthropologist Robert Hayden, called by the defense), describe as Serb propaganda the fact that periodicals from Belgrade "featured stories on the remote history of Serbs intended to inspire nationalistic feelings." 433 The "remote history" in question refers to the Second World War. That period, as the Tribunal mentions elsewhere in the decision, with the type of understatement that led to the British libel trial in Irving v. Penguin Books, 434 was a "tragic time, marked by harsh repression, great hardship and the brutal treatment of minorities. It was a time of prolonged armed conflict, in part the product of civil war, in part a struggle against foreign invasion and subsequent occupation." 435 One hoping to read even a superficial account of the fascist political structure of NDH Croatia, or the widespread atrocities committed by the Ustasha-those committed against the Jews comprehensively detailed in Volume II of Raul Hilberg's The Destruction of the European Jews ${ }^{436}$ - will be disappointed. Instead, the "credible history" presented by the ICTY judges states that "Three distinct Yugoslav forces each fought one another: the Ustasha forces of the strongly nationalist Croatian State, supported by the Axis powers, the Chetniks, who were Serb nationalist and monarchist forces, and the Partisans, a

\footnotetext{
433 Prosecutor v. Tadic, $\uparrow 91$.

434 See infra.

435 Prosecutor v. Tadic, $\uparrow 61$.

$4{ }^{6}$ Raul Hilberg, The Destruction of The European Jews, $3^{\text {rd }}$ ed., vol. II, (New Haven: Yale UP, 2003), 756-765.
} 
largely communist and Serb group.” ${ }^{437}$

Let us attempt to break down that sentence. First, the ICTY's history qualifies the Ustasa as "forces of the strongly nationalist Croatian state," and while this is true in the same way it is true that Nazis were forces of the strongly nationalist German state, the claim is significant for what it fails to state. In Hilberg's words, "the underlying philosophy of the [Croatian] state was FascistCatholic." ${ }^{38}$ The United States Holocaust Memorial Museum is somewhat less reserved than Hilberg in its characterization of the Ustase as "fanatically nationalist, fascist, separatist, and terrorist." ${ }^{3} 9$ The "tragic time, marked by harsh repression, great hardship and the brutal treatment of minorities," (as the ICTY describes it) is less euphemistically described by Hilberg's account of half the Jewish population of Croatia's internment in one or the other of NDH Croatia's seven labor or two extermination camps. 440 Of the two extermination camps, Jasenovac is the most well known, and it is primarily there that Jews (along with Serbs, who comprised the majority of the victims, as well as Roma and political opponents) died of typhus, torture, drowning, knifings, and blows to the head with hammers. ${ }^{41}$ Walter Laqueur and Judith Tydor Baumel describe Ustasa killings as "madness", 442 a sentiment echoed by General Edmund Glaise von Horstenau, the Wehrmacht's Plenipotentiary General in NDH, one of the

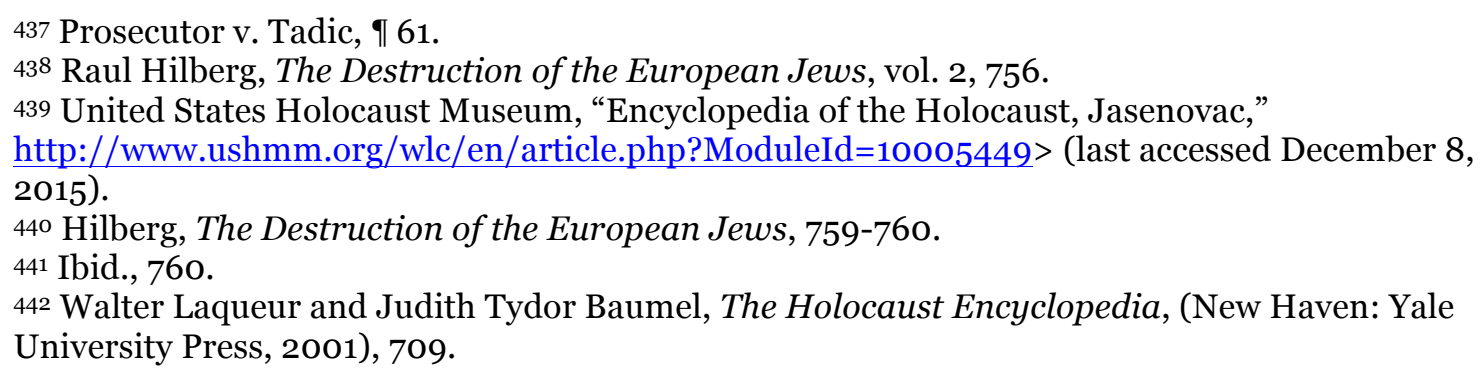


many Italian and German officials who complained about "the lawless and chaotic" methods of the Ustase. 443

The Tadic judgment mentions Jasenovac-memorialized by the USHMMonly three times, and only twice in the portion of the judgment devoted to history. First, it emerges in the context of Serb propaganda, and "stirring up Serb nationalistic feelings.” The ICTY judges write: “Among much other suffering, many Serbs, including the accused's mother, had been forcibly deported by the Ustasha to a concentration camp at Jasenovac where many died and all were illtreated." 444 The second mention of Jasenovac occurs in a paragraph directly addressing a "campaign of propaganda" orchestrated by the Serbs, and it is referred to in a quote, attributed only to "Serb-dominated media," 445 as a "symbol." The final mention of Jasenovac in the "reliable" history written by the ICTY concerns the accused. "During the Second World War," wrote the judges, "his mother had been confined to the Jasenovac prison camp which was operated by Croats."

The Tadic judgment nearly instructs the reader in greater detail about the Hapsburg occupation than it does about the death camp at Jasenovac. In fact, it is not possible to know what it was, other than a place of ill treatment-a prison or concentration camp-where many died. And thus, judicial history determines what counts as history, but also what history is entitled to leave out of its account.

\footnotetext{
443 Richard Breitman, US Intelligence and the Nazis, (Cambridge: Cambridge University Press, 2005), 204. 444 Tadic judgment, $₫ 83$.

445 Ibid., ๆ88.
} 
The historiography of Yugoslavia continues to be contentious, and nothing arguably illustrates this better than Josip Glaurdic's scathing review 446 of the recently published result of Charles Ingrao's “Scholar's Initiative," an eight-year project involving three hundred scholars from thirty-one countries to attempt to resolve the most enduring controversies in the historical scholarship on Yugoslavia. 447 Glaurdic is unsparing in his criticisms of the volume, and some objections certainly seem legitimate, in particular the instances of plagiarism, if confirmed. However, the importance of Ingrao's initiative in the context of the historiography of war crimes tribunals, and Glaurdic's exasperation over inaccurate points of varying importance, is that attempts to write the one last definitive history of anything-let alone of recent and highly-charged conflictual events-is as incautious as it is unsuccessful. Richard Evans details a remarkably long list of complaints made in the press after the Irving trial at which he appeared as an expert on behalf of Deborah Lipstadt and Penguin Books, many expressing concern with a judicially enforced single narrative about the Holocaust which would result in an atrophy of important questions about the events..$^{448}$ Evans takes pains to distinguish these objections-with which he would have agreed had the trial actually been about imposing a single version of history-with what the Irving trial did address, that is, the standards of historical scholarship. The standards, for Evans, are what distinguish ideologically-driven twisting of sources (and omissions) from legitimate debate about the

446 Josip Glaurdic, "Review Essay: Confronting the Yugoslav Controversies: A Scholar's Initiative," 2010, East European Politics and Societies (24) 294.

447 Charles Ingrao and Thomas A. Emmert, eds., Confronting the Yugoslav Controversies: A Scholars' Initiative (West Lafayette, IN: Purdue University Press).

$44^{8}$ Richard Evans, Lying About Hitler (New York: Basic Books, 2002), 251-259. 


\section{Holocaust. 449}

In the Irving trial, a libel suit was initiated by David Irving in Great Britain, where libel law places the burden of proof on the defendant. The issue in question was whether Deborah Lipstadt was entitled to characterize Irving as a Holocaust denier. Irving's position was that he was a serious scholar and historian and thus, that his reputation had been harmed by Lipstadt, and her publisher, Penguin Books. The defense proceeded to inundate Judge Charles Gray's court with expertise detailing the ways in which, over the course of his career, Irving had oriented his work towards a denial of the Holocaust, and had not treated his sources and evidence in an objective, fair, or scholarly manner. To arrive at a verdict, Judge Gray formulated the standard of the "conscientious historian." 450 The misrepresentations and distortions of historical evidence, found in nineteen separate instances of Irving's work were found to have fallen short of that standard, according to Judge Gray's 350-page judgment.451

One is entitled to wonder whether the ICTY's historical treatment of the former Yugoslavia would meet the standard of the "conscientious historian." What is certain is that the kind of history that it did generate is incomplete, and would cause some perplexity from the vantage point of scholarship undertaken on the Holocaust, in particular its treatment of NDH Croatia and the atrocities committed during the Nazi satellite's existence. Thus, its own claims to having

\footnotetext{
449 Ibid., 256-266.

450 Evans, Lying About Hitler, 227.

451 Irving v. Penguin Books Ltd., No. 1996-I-1113, 2000 WL 362478, ๆ 1.3 (Q.B. Apr. 11), appeal denied (Dec. 18, 2000).
} 
established a historical record, "beyond reasonable doubt" to silence deniers is of historical and legal concern. In fact, silencing deniers, when seen as a judicial function, apparently involves silencing episodes of history-in this case the Holocaust-which paradoxically serves as the very model of denial (a moral and in some cases criminal offense) the ICTY has appropriated.

Other difficulties are related to the historian's role in war crimes prosecutions, in particular when historians are personally invested in the events about which they later testify as experts. The case of the International Criminal Tribunal for Rwanda's first judgment, in Prosecutor v. Akayesu, is instructive in this respect. Historian Alison Des Forges testified as an expert, both on the history of Rwanda-which Trial Chamber I saw fit to recite at length, from precolonial times to $1994^{45^{2}}$-as well as to interpret broader events, well beyond the scope of Akayesu's indictment, as constituting preparation and execution of genocide. These views had been endorsed by the Human Rights Watch and FIDH sponsored "International Commission of Inquiry" (ICI), in a 1993 report Des Forges co-authored.

Des Forges was the only historian cited by the ICTR in its thirty-three paragraph history of Rwanda, as well as its eighteen paragraph finding that genocide had occurred as a historical fact in Rwanda in 1994. Des Forges' testimony provided the court with its basis for findings on issues as diverse as political and territorial organization, Rwandan law, the military, weapons shipments, the economy, religion, as well as a unique-and arguably influential452 Prosecutor v. Akayesu, Judgment, ICTR 96-4-T, ๆ 78. 
manner of disqualifying the previous government's claims of attacks or infiltration by the other party signatory to the Arusha Peace Accords of 1993, the Rwandan Patriotic Front, who had invaded Rwanda from Uganda in 1990.453 The Rwandan President's entourage, the Trial Chamber noted, on the basis of Des Forges' sole historical testimony, had disseminated propaganda and fabrication, characterized, according to the judgment, "as 'mirror politics', whereby a person accuses others of what he or she does or wants to do." 454 This constitutes a powerful explanatory claim; one that in the ICTR's first ever judgment certainly set a tone and even suggested how evidence should be weighed and credibility assessed. It is so powerful a disqualifying device that its uncritical inclusion in a court-written history poses a double problem of evidence: that is, the nature of the evidence that supports the claim, and the fact that the device may later be used to assess the credibility of claims regarding historical events.

Des Forges' involvement in the International Commission of Inquiry led to her testimony in other trials regarding Rwandans suspected of involvement in the 1994 events, but the reception she received in some domestic courts was not as uncritical as it appears to have been before the ICTR. The Canadian Federal Court of Appeals, for instance, was sharp in its assessment of her credibility as well as her objectivity as a historian. Testifying against Leon Mugesera, facing immigration charges in Canada, Des Forges (much as she did before the ICTR in

\footnotetext{
453 Barrie Collins, Rwanda 1994: The Myth of the Akazu Genocide and Its Consequences, (London, Palgrave Macmillan, 2014) 56.

454 Ibid., ๆ 99.
} 
Arusha) defended the report of the ICI, as well as her activism. The Canadian court highlighted the following statement:

She admitted, at the end of the cross-examination: "If you wish to argue that we chose our evidence to support our conclusions, you are entirely correct. We chose our evidence to support our conclusions. There were many facts concerning the historical period which did not appear to us relevant. We did not include them. We chose our evidence after we had weighed all of the facts and reached our conclusions. We made an orderly presentation as you do as a lawyer to support your contention" (a.b. vol. 10, p. 3075 - emphasis added by the Federal Court of Appeals). 455

The prosecutorial flavor of her expert testimony-which went unnoticed in the context of a UN trial, where in fact she was afforded tremendous deference and her testimony great weight-was remarked upon in Canada in an unambiguously critical manner:

Even making the debatable assumption that a member of a commission of inquiry, who is actually its co-chairperson and co-author of the report, can be described as an objective witness concerning the conclusions of that report, Ms. Des Forges testified much more as an activist than as a historian. Her attitude throughout her testimony disclosed a clear bias against Mr. Mugesera and an implacable determination to defend the conclusions arrived at by the ICI and to have Mr. Mugesera's head. 456

The difference in treatment of Des Forges as a witness by the UN and Canadian bodies emphasizes the striking difference in the acceptable scope of a historian's testimony in domestic as opposed to war crimes courts. This phenomenon was even remarked upon by Robert Donia, who testified for the Prosecution in the

455 Mugesera v. Canada (Minister of Citizenship and Immigration), [2004] 1 F.C.R. 3, 232 D.L.R. (4th) 75, 309 N.R. 14, 31 Imm. L.R. (3d) 159, par 99. Reversed by the Canadian Supreme Court: Mugesera $v$. Canada (Minister of Citizenship and Immigration), [2005] 2 S.C.R. 100, 2005 SCC 40. Des Forges' testimony was not considered by the Supreme Court. 
Blaskic case in The Hague, as "more an extended lecture on regional history than court testimony as it might take place in an American court, where a judge would neither need nor welcome such an extensive background portrayal”. ${ }^{457}$

Aleksandar Jokic has referred to this moral and judicial differential as "the normative divide," a concept that captures the fact that acts that would be blameworthy in Western democracies or Western courts, appear acceptable if performed abroad, in relation to an ostensible challenge against, or even a narrative about genocide. $45^{8}$ Beyond the moral question, however, lies the historical one, and it is intertwined with the notion of justice. As Judith Shklar has argued about the legalist disposition of lawyers and legal theorists-that is, that they insist rather dogmatically on a separation between politics and law, when in fact the notion that they can be so neatly distinguished is a conservative self-delusion459-so, too, we are challenged to look at the connection between history and the law.

But while it is obviously misguided to insist that history and law never do and never ought to intersect, it is also arguably even more dangerous to suggest that judges can capably do the work of historians and that historians can safely perform the functions of the judge. Again, Carlo Ginzburg's point appears apposite here: "if one attempts to reduce the historian to a judge, one simplifies and impoverishes historiographical knowledge; but if one attempts to reduce the judge to historian, one contaminates-and irreparably so-the administration of

\footnotetext{
457 Cited in Wilson, "Judging History: The Historical Record of the International Criminal Tribunal for the Former Yugoslavia," 928. $45^{8}$ Aleksandar Jokic, "Genocidalism," The Journal of Ethics, 8 (3) (2004), 251-297, 293. 459 Judith Shklar, Legalism, 1-11.
} 
justice." 460 Shklar's view that legalism is an ideology ought not stand for the proposition that either history or law are well served by their respective instrumentalization. A court writing history-a single, definitive history, the denial of which is in some instances subject to criminal sanction-is also performing an ideological role. ${ }^{461}$ While Tzvetan Todorov formulates the classic legalist objection to the trial of Klaus Barbie, writing that "what is especially worth criticizing ... is not that they wrote bad history, it's that they wrote history at all, instead of being content to apply the law equitably and universally," 462 the problem is compounded when, even assuming that judges are qualified to reconstruct events for anything wider in scope than what is required for the ends of a discrete criminal prosecution, according to its rules of evidence and procedure, they determine a preferred historical interpretation of that reconstitution.

Emanuela Fronza's critique of the criminalization of negationism (or denial) emphasizes the ideological nature of the judicial protection of a single version of history. Rational and democratic systems of government treat people like citizens, but when they criminalize who people are or what they want, they treat them as enemies. ${ }^{463}$ Fronza isolates the historiographical problem of the court-sanctioned version of history: "The tribunal will inevitably find itself, in

460 Ginzburg, The Judge and the Historian 118.
461 Emanuela Fronza, "Punishment of Negationism: The Difficult Dialogue between Law and
Memory", 30 Vt. L. Rev. 609 (2005-2006) 621, 622.
462 Tzvetan Todorov, "The Touvier Affair," in Memory, The Holocaust And French Justice: The
Bousquet And Touvier Affairs 114, 115 (Richard J. Golsan ed., 1996), 116 cited in Wilson,
"Judging History: The Historical Record of the International Criminal Tribunal for the Former
Yugoslavia," 912.
463 Fronza, "Punishment of Negationism: The Difficult Dialogue between Law and Memory," 622. 
this case, sanctioning one interpretation as official and discrediting the idea that more than one historical school exists. Yet, in truth, a multitude of historical schools exists.464"

Criminal law seeks a single, definitive reconstruction of an event, but only as a means to determine whether the state has established the culpability of an individual according to rules of evidence and a standard and burden of proof. The historical approach selected by a tribunal will necessarily be subordinated to the needs of the judicial function.

For example, David Chuter argues, following the analogy of the intentionalist-functionalist debate in Holocaust scholarship465 that it would have been impossible, had Hitler been tried, to settle on one approach to the detriment of another, as most proponents of a historical school will generally concede that there are valid objections to it.466 It may be, however, that in some cases a side in a historical debate is chosen. This will occur when or if one approach presents greater consistency with judicial, usually prosecutorial, objectives. Thus, in the case of Nuremberg, neither historiographical approach lent itself well to a smooth prosecution. It is noteworthy that then, functionalism had barely emerged, as Hilberg's Destruction of the European Jews was yet unpublished. ${ }^{467}$ For the Nuremberg court, conspiracy, as participation in a common plan to commit

\footnotetext{
464 Ibid., 621.

465 See, too, Hilberg, The Politics of Memory: The Journey of a Holocaust Historian, (Chicago: Ivan R. Dee, 1996).

466 David Chuter, War Crimes: Confronting Atrocity in the Modern World, (Boulder CO: Lynne Reiner, 2003), 152. 467 Hilberg, The Politics of Memory, 66.
} 
crimes against the peace, was the legal device most suitable to apply. 468

International war crimes tribunals may have difficulty performing their judicial function, moreover, when the historical nature inherent to these prosecutions imposes, if not a dominant interpretation, then at least a sense of a widely accepted version of history. 469 David Paccioco argues that the events creating international tribunals impose an interpretation of history on judges that is practically irresistible, and which creates expectations from judges that they will find in the record what they think that they already know.

This creates an irresistible temptation-however well intentioned-to prejudge issues, one that traps both the innocent and the guilty. ${ }^{470}$ There is little allowance made for the idea that the received history can be wrong, and thus that innocents can be convicted as a result, and while judges decide on evidence, their assessment of it will inevitably be based on their pre-existing beliefs about the events 471 that led to the creation of the "law-like political institutions" 472 in which they are called to judge. Paccioco points out that part of the reason for history's influence on these proceedings lies in the very creation of international criminal courts, ${ }^{473}$ namely in the attempt to promote reconciliation, in addition to their prosecutorial and punitive functions. In turn, this preoccupation is transformed

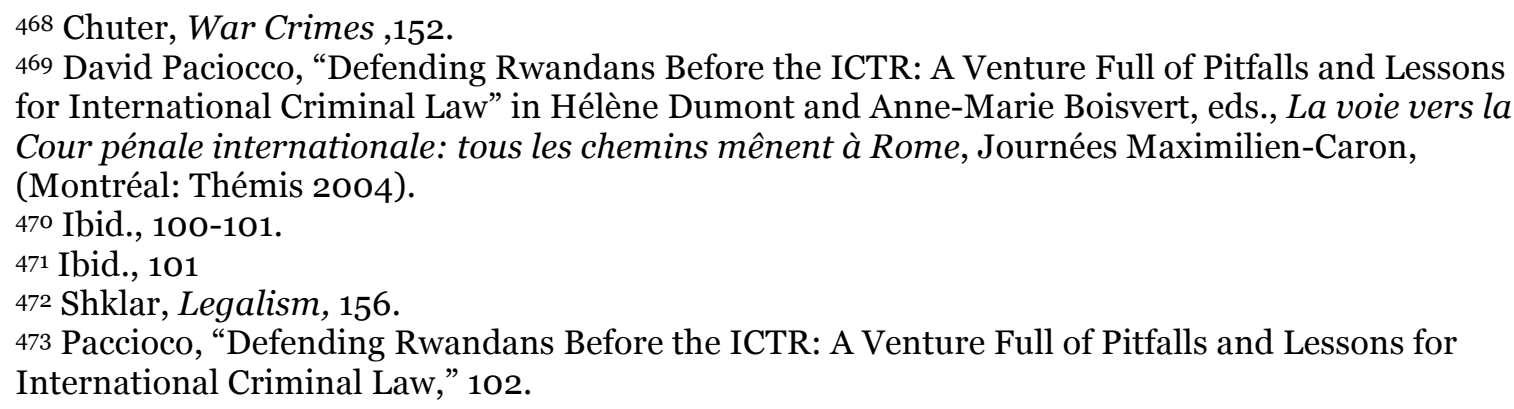


into a "search for historical truth" 474 which justifies recourse to what Almiro Rodrigues and Cécile Tournaye call a "free system of evidence," one that admits hearsay, and indeed, whatever type of evidence judges consider relevant and which has probative value. 475 Rodrigues and Tournaye consider that these rules of evidence were deemed necessary in anticipation of the difficulties that the ICTY would encounter in gathering evidence in the service of historical truth. ${ }^{476}$ Thus, from its inception, the contemporary UN war crimes tribunal, as a judicial body, both invests itself in the search for historical truth, and-perhaps surprisingly from the vantage point of historians-loosens the rules of evidence to do so.

Reconciliation is seen by proponents of the historical school of international law as establishing a "memory" that would, as Paccioco writes, "shame offending parties into distancing themselves from their past." 477 Participants in the establishment of the United Nations ad hoc courts have explicitly acknowledged this intent. For instance, Michael Scharf, writing an oped in the summer of 2004 arguing against Slobodan Milosevic's continued selfrepresentation, stated that the ICTY had been established with three objectives:

In creating the Yugoslavia tribunal statute, the U.N. Security Council set three objectives: first, to educate the Serbian people, who were long misled by Milosevic's propaganda, about the acts of aggression, war crimes and crimes against humanity committed by his regime; second, to facilitate

\footnotetext{
474 Almiro Rodriguez and Cécile Tournaye, "Hearsay Evidence," in May, Tolbert, Hocking, Roberts, Jia, Mundis, and Oosthizen, eds., Essays on ICTY Procedure and Evidence in Honour of Gabrielle Kirk McDonald, (The Hague: Kluwer, 2001), 296 475 Rodrigues and Tournaye, "Hearsay Evidence," 296. 476 Ibid. 477 Ibid.
} 
national reconciliation by pinning prime responsibility on Milosevic and other top leaders and disclosing the ways in which the Milosevic regime had induced ordinary Serbs to commit atrocities; and third, to promote political catharsis while enabling Serbia's newly elected leaders to distance themselves from the repressive policies of the past. May's decision to allow Milosevic to represent himself has seriously undercut these aims. ${ }^{478}$

These clearly appear to be political objectives, and while Shklar would be skeptical of the idea that the judicial function can ever be really separated from politics, it is one thing to admit the influence of politics on law or even to acknowledge its logical necessity, but quite another to establish a body with objectives that appear antithetical to the judicial function. Of concern is the effect that the political nature of this establishment can have on the kind of history it writes, as well as on the history that will be written by others about the events to which these tribunals devote their work.

The Political Quality of History in International War Crimes Trials

The media played an essential role in establishing a dominant narrativedescribed by Diana Johnstone as a "collective fiction" 479 with respect to Yugoslavia: it was, according to the standard narrative, a "prison of peoples" in which the Serbs oppressed all other ethnic groups ${ }^{480}$. When the oppressed of

\footnotetext{
${ }^{478}$ Michael Scharf, "Making a Spectacle of Himself: Milosevic Wants a Stage, Not the Right to Provide His Own Defense" Washington Post (August 29th, 2004), p. B2. 479 Diana Johnstone, Fools' Crusade: Yugoslavia, NATO, and Western Delusions, (New York: Monthly Review Press, 2002) 4. 480 Ibid.
} 
Yugoslavia attempted to liberate themselves from the brutal dictatorship of Slobodan Milosevic, he-and the Serbs (a thoroughly evil group of people)embarked upon a policy of ethnic cleansing, about which the international community did nothing. Milosevic and the Serbs had a policy of systematic rape, concentration camps, and committed genocide in the locality of Srebrenica. U.S. bombing forced Milosevic to participate in peace talks in Dayton, and to make up for the international community's inaction in the face of Nazi-like horror, the UN Security Council established a body just like Nuremberg. ${ }^{481}$

Diana Johnstone argues that almost every material particular supporting this narrative is inaccurate; but that once the equation had been drawn between the Nazi Holocaust and the Yugoslav wars, created by "reporters under pressure to meet deadlines, editors further simplifying the story for readers assumed to be both ignorant and impatient, paid propagandists and public relations officers" it was too late. 482 The political changes that invested a post cold war single superpower with the ability to declare itself the judge of the moral and legal questions it had itself framed proved irresistible. A virtually unimpeachable truth had been established by repeating a narrative that relied on the Holocaust often enough. The power of the historical analogy triggered action; in the interests of justice, something had to be done.

The effects of the media's contribution to the establishment of the ICTY through its reliance on Holocaust imagery cannot be understated. The most 
influential scholars, authors, and pundits do not even attempt to conceal it.

Samantha Power's influential A Problem From Hell: America in an Age of

Genocide makes it unambiguous:

We will never know whether a different war in a different place at a different time would have eventually triggered a different process. But one factor behind the creation of the UN war crimes tribunal for the former Yugoslavia was the coincidence of imagery between the Bosnian war and the Holocaust. 483

The strategy yielded dividends that are still apparent today as even the Obama administration's 2010 National Security Strategy demonstrates the strategic value of U.S.-dominated ad hoc courts, and U.S. involvement-where it can control processes in its interest-in the proceedings of the International Criminal Court.

International Justice: From Nuremberg to Yugoslavia to Liberia, the United States has seen that the end of impunity and the promotion of justice are not just moral imperatives; they are stabilizing forces in international affairs. The United States is thus working to strengthen national justice systems and is maintaining our support for ad hoc international tribunals and hybrid courts. Those who intentionally target innocent civilians must be held accountable, and we will continue to support institutions and prosecutions that advance this important interest. Although the United States is not at present a party to the Rome Statute of the International Criminal Court (ICC), and will always protect U.S.

\footnotetext{
483 Samantha Power, A Problem From Hell: America in an Age of Genocide, 483. See, too, Ivan Simonovic, "The Role Of The ICTY In The Development Of International Criminal Adjudication," 23 Fordham Int'l L.J. (1999-2000) 440, 442: "It was the pressure of world public opinion, viewers of the media with global coverage bringing the reality of the horror to millions of homes that were the catalyst for a response from the international community. Given its earlier intervention in Iraq, the U.S. Administration was not eager to get directly involved, and Europe preferred recourse to multilateralism as well. The fact that the end of the Cold War had brought a period of better understanding between the permanent members of the Security Council enabled the United Nations to become actively involved." Christopher Rudolph (2001) "Constructing an Atrocities Regime: The Politics of War Crimes Tribunals," International Organization, 55 (3): $655^{-691}$, is much in the same vein.
} 
personnel, we are engaging with State Parties to the Rome Statute on issues of concern and are supporting the ICC's prosecution of those cases that advance U.S. interests and values, consistent with the requirements of U.S. law. 484

Thus, what preceded the establishment of these contemporary bodies was the power of history. Today, still, international justice, framed as national security, relies on the Nuremberg precedent, arguably less in its legal form than in its cultural and historical embodiment. It does not follow, however, that the institutions created in the nineteen-nineties write the history of the events they adjudge in the way historians, over the past decades, have refined their understanding of the workings of Nazi Germany and of the Holocaust. Yet that is perhaps precisely the history we imagine when we think of Nuremberg. To conflate the careful scholarship of Raul Hilberg and Christopher Browning, for instance, with the approach of those who established the narratives of this immediate history is to mistake the approach and training of the historians, on the one hand, with the unique constraints and objectives of journalism.

"It is not a criticism of the media," write David Chuter, "to say that its priorities are different from that of courts and investigators," 485 and how much more so do they differ from those of historians. The work of historians can pose a problem in its use in courts-amounting to what Chuter characterizes as a "category error." This means that little if any of the scholarly production in history seeks to establish an individual's guilt for an offense beyond a reasonable

484 National Security Strategy, President of the United States of America, May 27 $7^{\text {th }}, 2010$.
485 Chuter, War Crimes, 153. 
doubt based on judicial standards. ${ }^{486}$ Journalism exacerbates the misfit considerably given the time and commercial constraints of the trade.

Journalists have been more prompt to assert guilt-and with greater confidence and speed-than have historians in articles, and on some occasions, books. Many journalists have been called upon to testify before the contemporary war crimes tribunals. ${ }^{487}$ Yet demands of space and time inherent in the practice of journalism lead to preferring extravagant claims over more tentative ones, higher estimates of casualties over lower ones. 488

Raul Hilberg's careful assessment of Jews killed in the Holocaust is inferior to the standard six million-and, as Chuter puts it, "because of the limitations that the media work under, shorthand comparisons are often used to convey what busy and often inexpert journalists want their busy and poorly informed audiences to understand." 489 Chuter cites Pulitzer award-winning journalist Roy Gutman ${ }^{490}$ as an example of amplification of claims: he had written, in 1992, that every woman aged fifteen to twenty-five had been raped in Bosnia-Herzegovina. 491

Less commonly known is the little remarked upon fact that Roy Gutman was the source for the ICTY Prosecutor's indictment of a certain "Gruban" for a

\footnotetext{
486 Ibid.

487 Ibid.

488 Ibid.

489 Ibid.

490 See Roy Gutman, Witness to Genocide, (New York: Macmillan, 1993)

${ }^{491}$ Chuter, War Crimes, 153.
} 
series of rapes. ${ }^{492}$ The indictment was subsequently withdrawn, as Gutman's source-a fellow Yugoslav journalist-had, in response to Gutman's queries about whether his colleague could identify the "biggest rapist" in the region, named Gruban, a fictional character created by a local novelist. 493

This incident-the actual indictment of a fictional character before a war crimes tribunal established by the United Nations on the basis of a journalist's communication of evidently unreliable hearsay evidence-tends to demonstrate a clear difference in the manner in which journalists and historians treat the concept of a source. As for the judicial component of this embarrassing imbroglio, while it is difficult, perhaps impossible, to measure, it is worth inquiring into the potential influence of the journalistic approach-the rush to judgment on such a tenuous basis-on the carelessness with which this indictment was proffered by the Prosecutor then confirmed by United Nations judges. Journalists played a tremendous role in stoking outrage for reasons detailed above-lack of time to investigate claims, as well as a preference for more colorful narratives-and as a result, they resorted instead to very powerful discursive historical shorthand. "Moral certainty," however, as Carlo Ginzburg put it, "does not have value of proof." 494 Yet, references to the Holocaust were consistent in the reporting on the Yugoslav wars, 495 and more than serving merely as shorthand, these references created-then reinforced-the kind of climate of preconceived belief among judges that Paccioco rightly critiques.

\footnotetext{
492 Jokic, Genocidalism, 291.

493 Ibid.

494 Davidson, "Carlo Ginzburg and the Renewal of Historiography," 306.

495 Chuter, War Crimes, 154.
} 
A legalistic mind might find the narrative quality of some historical works on the events that courts are called to adjudicate objectionable-the emotional, and perhaps melodramatic quality of what fills in the gaps where footnotes are absent, can make criminal lawyers uncomfortable. This phenomenon could be called "narrativism," and would be defined as a misuse of the narrative device in absence of evidence-and in particular in the presence of contrary evidence-to create an emotional response in the reader. Two examples from Samantha Power's influential America in an Age of Genocide may illustrate the problem. Power begins her book, which is not the work of a historian, though its largely positive reception and Pulitzer Prize (for General Non-Fiction) make that irrelevant-with the following paragraph:

On March 14, 1921, on a damp day in the Charlottenburg district of Berlin, a twenty-four-year-old Armenian crept up behind a man in a heavy gray overcoat swinging his cane. The Armenian, Soghomon Tehlirian, placed a revolver at the back of the man's head and pulled the trigger, shouting, "This is to avenge the death of my family!" The burly target crumpled. If you had heard the shot and spotted the rage distorting the face of the young offender you might have suspected that you were witnessing a murder to avenge a very different kind of crime. But back then you would not have known to call the crime in question "genocide." The word did not yet exist. 496

The legalist reader is perhaps the kind of reader that Carlo Ginzburg might have had in mind when he described as "naïve" the person who would search in vain for a footnote to support a clearly conjectural claim. 497 Is there not conjecture in the very familiar wording observed above, "if you had heard the shot," and does

496 Power, A Problem From Hell: America in an Age of Genocide, 1.

497 Ginzburg, The Judge and the Historian, 115. 
this formulation not eerily resemble Eileen Power's description of the life of Bodo in Medieval People? Ginzburg points out the implausibility of Bodo-who was from Île-de-France-singing an Anglo-Saxon incantation. ${ }^{498}$ The problem resides, here, in the filling of gaps in evidence with implausible or questionable conjecture. But in Samantha Power's retelling of Tehlirian's murder of Pasha, the reader is not invited to understand the young Armenian's statement as conjecture; alternatively, if it is conjecture, it is not only implausible, but contrary to existing evidence regarding the event, in particular transcripts of Tehlirian's trial for murder499-in which the accused himself, as well as a witness state that nothing was said before the assassination of Pasha. That "this is to avenge the death of my family"-now reproduced in other pop-historical accounts, footnoting Power-was the broad interpretation one could reasonably hold of Tehlirian's defense, as well as the outcome of his trial (an acquittal by reason of insanity, as a result of trauma caused by witnessing the slaughter of his family) certainly seems sound, it is another thing altogether to gratuitously place that quote-as if it had been spoken, when evidence tends to show that it was not-at the very beginning of Power's book.

In another instance, Power quotes an account from a story published in the Washington Post on July $15^{\text {th }}$, 1995, which possesses a quality that can be described as "the anecdote that nobody could have possibly witnessed," and which again, perhaps, weaves conjecture with evidence: a young woman, a

498 Ibid., 114.

499 Available at http://armenianhouse.org/wegner/docs-en/talaat-1.html (last accessed December $8,2015)$. 
refugee from Srebrenica, hangs herself, but before that moment, she sobs alone.

It is perhaps naïve to wonder how one goes about establishing that she was sobbing if she was alone. It is, one can suppose, an assumption that one sobs before suicide.

The young woman died with no shoes on. Sometime Thursday night she climbed a high tree near the muddy ditch where she had camped for 36 hours. Knotting a shabby floral shawl together with her belt, she secured it to a branch, ran her head of black hair through the makeshift noose and jumped... She had no relatives with her and sobbed by herself until the moment she scaled the tree.50o

Power employs the quote from John Pomfret's emotional front page July $15^{\text {th }}$, 1995, Washington Post article, about the young woman's suicide, to set up a scene at a President Clinton cabinet meeting, in which Vice-President Gore, she writes, had referred to the photograph accompanying Pomfret's article:

Gore told the Clinton cabinet that in the photo that accompanied Pomfret's story, the woman looked around the same age as his daughter. "My twenty-one-year-old daughter asked about that picture," Gore said. "What am I supposed to tell her? Why is this happening and we're not doing anything?" [...] "My daughter is surprised that the world is allowing this to happen," Gore said, pausing for effect. "I am too." Clinton said the United States would take action and agreed, in Gore's words, that "acquiescence is not an option." 501

The sobbing conjecture could appear puzzling enough to prompt the skeptic to verify Pomfret's article to examine his evidence: had somebody witnessed the woman sobbing alone? A Lexis-Nexis search of the Washington

500 Ellipsis in Power, A Problem From Hell, 413.

501 Power, A Problem From Hell, 413. 
Post's front page on July $15^{\text {th }}, 1995$, reveals not only Pomfret's story, but another, by Samantha Power, "special to the Washington Post" (from Sarajevo), with additional reporting by John Pomfret (in Tuzla). There was no sourcing, in the Pomfret piece, to indicate how he knew the woman had sobbed by herself. The prose seems uncharacteristically literary, and the article, according to LexisNexis, is accompanied by a Reuters photo of Muslim women crying. What to make of Power's account of Gore's reaction to the photo of a young woman hanging from a tree, a photo that according to her, "accompanied” Pomfret's article?

A microfilm search of the front page of the July $15^{\text {th }}, 1995$ issue of the Washington Post reveals that John's Pomfret's article appears in a box, beneath the fold, on the right hand side, without illustration. It is continued, on page A-17, and is accompanied by a Reuters photo of Muslim women and children crying. Above the fold that day, under the headline "Residents Sizzle," the Washington Post published a photo of a young woman pouring water down her neck. No photo of a hanged young woman ran alongside John Pomfret's article, as stated by Power, nor was it run on the following days.

Power's account of the cabinet meeting footnotes Bob Woodward's The Choice, at pages 162-163. Woodward writes, regarding Vice-President Gore:

He noted that the front page of the Washington Post over the weekend had described a young woman, just one of the 10,000 refugees from Srebrenica, who had committed suicide by tying a floral shawl and her belt together to hang herself from a tree. A picture of the woman had run all 
over the world. Gore said she seemed to be the age of his own daughter. "My twenty-one-year-old asked about the picture."502

Power's claim that this photo appeared accompanying John Pomfret's July $15^{\text {th }}$, 1995 article is inaccurate. The Washington Post does not support it, and neither does Woodward-who, carefully (for obvious reasons) references only the Washington Post's description of the suicide, claiming rather that the picture had "run all over the world," and that Gore's daughter, perhaps an avid reader of foreign newspapers, had asked about the picture. Does is matter? It matters in that this account-like many others in Power's book-is offered to illustrate a significant moment, an epiphany, in this case, a shift in U.S. foreign policy effected by Gore's response to a photo that was published in the Washington Post, one that prompted his daughter to ask questions that were intolerable.

The photograph was described in a Guardian piece by Lorna Martin, published April 17"th 2005, titled "Truth Behind the Picture That Shocked the World".

The photograph of Ferida Osmanovic was published on front pages across the world soon after the fall of Srebrenica on 11 July, 1995. It prompted a series of questions in the US Senate by those concerned about Bosnia's war. What was her name, where was she from, what humiliations and depravations did she suffer, had she been raped, did she witness loved ones being killed?

At a meeting with President Bill Clinton, Vice President Al Gore referred to a front-page story in that day's Washington Post. 'My 21-year-old daughter asked about this picture,' he told the President, showing him the newspaper. 'What am I supposed to tell her? Why is this happening and

502 Bob Woodward, The Choice (New York: Simon and Shuster, 1996). 
we're not doing anything? My daughter is surprised the world is allowing this to happen. I am too." ${ }^{503}$

Here, too, the point is that this is a significant photograph, described by Martin, ten years after its publication "on front pages across the world," as having prompted questions in the Senate. Martin writes that Vice President Gore showed President Clinton "that day's Washington Post," stating that his 21 year-old daughter asked him about the picture, in precisely the same terms as those crafted by Power. Here, journalism reproduces the errors of a former journalist's account of a conversation it is far from clear ever occurred, about a photograph that did not run in the Washington Post. The account appears in Gore's Senate webpage, the myth now apparently carved into stone. .504

Also strange is Power's contention that Clinton cabinet meeting occurred on July $15^{\text {th }}, 1995$, when page 161 of Woodward's book (the following two pages are footnoted in support of her account) places that meeting on Monday, July $17^{\text {th }}, 1995 \cdot \cdot^{505}$

Power's anecdote is one where a poignant photo of a hanged woman accompanies a front-page article in the Washington Post, and the Vice President brings it to the President's attention, the very same day. Does the account lose

503 Available at <http://www.guardian.co.uk/world/2005/apr/17/warcrimes.lornamartin>. 504 "Internationally, Gore was quicker than Clinton to advocate the use of military force in world trouble spots. While the president pondered what to do about the worsening crisis in Bosnia, the vice president pointed to a front page picture in the Washington Post of a twenty-one-year-old refugee who had hanged herself in despair. "My twenty-one-year-old daughter asked about that picture," said Gore. "What am I supposed to tell her? Why is this happening and we're not doing anything?" United States Senate, Albert A. Gore, Jr., 45th Vice President (1993-2001), http://www.senate.gov/artandhistory/history/common/generic/VP_Albert_Gore.htm>. 505 Woodward, The Choice, 161. 
narrative force if described in a manner consistent with the evidence? The accurate account is that Gore would have referred to a Washington Post article, "published over the weekend" (it was Saturday, July $15^{\text {th }}$ ) that described a hanging, a photo of which was apparently published elsewhere. ${ }^{506}$ That photograph both reminded him of his daughter, and caused his daughter to ask him why "the world" was doing nothing, a question he adopted as his own. The message in each account is the same: this photo changed foreign policy as a result of Gore's emotional response. In Power's account, however, the photo was published in the Washington Post, and Gore responded to it immediately. Both the press (specifically the Washington Post, to which Power herself contributed an article that day), and Gore appear more decisive in Power's inaccurate account. The conclusion seems to be that the media-and in particular, images, have the power to affect politicians and cause them to act despite their hesitations. The obvious problem is of course-and this example shows it welljournalists do not always treat evidence with care.

The difficulty is compounded when a journalist crafts a work imbued with scholarly pretense. Power's erroneous claims, in keeping with the trappings of scholarly methodology, are supported by footnotes, and yet it is those very footnotes that show them to be inaccurate. It is thus not an invitation to conjecture, to be weighed, then accepted or rejected: Power's assertions are offered as facts, supported by footnotes. Power correctly added the reference to

\footnotetext{
${ }^{506}$ I have been unable to locate any major French or English language publication that published the photo; however, there is a contemporaneous account stating that "some newspapers" did run it. James Fenton, Comment, The Independent, July $17^{\text {th }}$, 1995, page 15.
} 
Pomfret's piece in Woodward's account, and footnoted it accurately. No person having done that could honestly claim that the photograph of a woman hanging accompanied that article, and arguably less someone having herself published an article in the same paper that same day. Power misstates the date of the cabinet meeting, yet it stretches credulity that she would miss Woodward's reference to the date at which the meeting occurred. That date appears one page before the pages she footnotes. How does the writing process unfold? One thing is certain; it is not a scholarly process, much less a historical one. It can rather be imagined as a series of anecdotes, all emotional and powerful, fraught with victims and heroes, brought together to send a powerful message. Narrative license, even on insignificant matters, supports a strange subtext: to Power, accuracy does not matter; the story does, as does the appearance of careful research and accurate reference to evidence. Yet a genre tackling genocide, and the history of its understanding by the United States, as well as the history of the establishment of legal bodies, about which Power also states that they would not have been created without the coincidence of imagery with the Holocaust, requires meticulous attention to evidence. A wealth of footnotes and a stout bibliography do not make up for errors of fact, nor does a better story, or a noble cause. In fact, the enterprise becomes suspect as the reader is left baffled and wondering for what purpose an easily uncovered myth is planted in this narrative; one which would have served the thrust of her work just as well had she reported the facts-about reporting, ironically-with accuracy. 
History in International Relations and Academic International Criminal Law

I have attempted thus far to explore the relationship between law and history, as well as the effect of journalism on a certain idea of history. The subdiscipline of international relations, which can study international criminal law from the perspective of political science or the philosophy of international law, also employs history as evidence, data, as well as to provide examples to illustrate social scientific theoretical propositions. Academic international criminal law, too, employs history in a manner of interest to this essay: to account for, or more particularly to advocate for change in the substantive law. Such is the case of academic international criminal law's development of an unusual concept: the "Grotian Moment."

Paul Schroeder has addressed the issue of the relation between history and international relations scholarship with great care, seeking first to address commonly held misconceptions regarding the differences between the two fields. ${ }^{507}$ First, the notion that history addresses only the particular in great detail, while international relations theory addresses patterns and law-like generalizations; second, and related, is the idea that the difference between the two disciplines is that international relations is nomothetic while history is idiographic, a merely descriptive pursuit, which thirdly, seeks understanding in the sense of Verstehen-intuitive identification. ${ }^{508}$ Schroeder argues that while there is some plausibility to each of these claims, they can nonetheless serve to

${ }_{507}$ Paul W. Schroeder, "History and International Relations Theory: Not Use or Abuse, but Fit or Misfit," International Security, 22, (1) (Summer, 1997), 64-74, 65. 508 Ibid. 65. 
distort history to the point of caricature, thus granting license to political scientists (or scholars from other disciplines) to misuse and abuse elements of historical work to pursue what is mistakenly considered to be a strictly social scientific endeavor, that is explanation and prediction. ${ }^{509}$ This misconception holds that history is a merely descriptive undertaking, and while it is true that narration (and description) play a crucial role in the historical approach, this view fails to grasp that historical works, as Schroeder writes, "are clearly nomothetic in the sense that they develop hypotheses, assign particular causes for events and developments, and establish general patterns." ${ }^{10}$ History seeks to account for social change, and its methodology, perhaps "distressingly vague" by social scientific standards, ${ }^{511}$ consists in identifying under-explored or incorrectly interpreted phenomena, and marshaling all available evidence, arriving at a synoptic judgment, that is "a broad interpretation of a development based on examining it from different angles to determine how it came to be, what it means, and what understanding of it best integrates the available evidence." ${ }^{12}$ Misuse of history-in addition to the most obvious abuses resulting from incorrect factual claims, usually resulting from the reliance on other works in international relations-occurs primarily when historical findings are taken out of context and used as data without an adequate understanding of the key differences between history and political science: history seeks to account for change, it is concerned

\footnotetext{
509 Ibid., 65 .

${ }^{510}$ Ibid., 66.

${ }^{511}$ Ibid., 68.

512 Ibid.
} 
with acts of purposive human agency, not mere behavior, and historians form judgments about the causes, meaning and significance of social change. .513

The use of historical materials to classify states according to their democratic or autocratic nature-known in international relations as the democratic peace theory, the proposition that democracies do not go to war against each other-provides an illustration of a misfit between history and the social sciences.514 Indeed, from the perspective of historians, the cases used as data to test the theory have been removed from all context;515 they lose the complexity and richness of explanation, the continued refinement, debates and questions that continue to interest the discipline of history; historical events, thus employed, are effectively dehistoricized. As Schroeder writes:

The concept of what is to be discovered and explained (not change over historic time, but supposedly lawlike, structural correlations between fixed stylized phenomena); of the subject matter (not human conduct, acts of purposive agency, but behavior, phenomena to be stripped of their human, purposive element precisely in order to be manipulable and calculable for scientific purposes); and of the desired explanatory outcome (designed precisely to exclude synoptic judgment and to consist of proofs, preferably statistical-mathematical, of such correlations)-all these are so remote from and alien to what historical scholarship is about and always will be, that between it and this kind of endeavor no genuine conversation, much less fit and collaboration, is possible. $5^{16}$

Edward Ingram draws a similar conclusion, adding that historians, when examining the world of the political scientist, are bewildered by its curious

\footnotetext{
513 Ibid., 71.

514 Edward Ingram, "The Wonderland of the Political Scientist," International Security, 22 (1) (Summer, 1997), 53-63, 56.

515 Ibid., 56.

516 Schroeder, "History and International Relations Theory," 73.
} 
position on time, space, and causation, like Alice in Wonderland.517 Both Ingram and Schroeder argue in favor of something akin to a non-aggression pact between the two disciplines, but it could be argued that historians may have a responsibility greater than that of merely averting their gaze from political science's different perception of the phenomena they study. There are instances in international relations scholarship as well as the related scholarship in academic international criminal law where the use of historical materials goes beyond mere oversimplification or instrumentalization: it is employed to argue that international law has changed-without legislative intervention and in an virtually instantaneous manner-resulting in real consequences for real people. In this genre, the concept of the "Grotian moment," first developed by Richard Falk, but most recently expounded by Michael Scharf, is instructive. The Grotian moment refers to Hugo Grotius, widely considered the father of international law. Michael Scharf employs the expression as he marshals elements of history to assert a paradigmatic shift in law as a result of a dramatic historical event.518 In an article advocating that a controversial mode of criminal participation, joint criminal enterprise-or JCE, also known by some critics as "just convict everyone"519-which in one of its incarnations allows individuals to be held individually criminally responsible for crimes perpetrated by others that were

\footnotetext{
517 Ingram, "The Wonderland of the Political Scientist," 63. 518 Michael Scharf, "Seizing the 'Grotian Moment': Accelerated Formation of Customary International Law in Times of Fundamental Change,” Cornell International Law Journal, 2010, 43, 439 .

519 Shane Darcy, "Imputed Criminal Liability and the Goals of Criminal Justice," Leiden Journal of International Law, 20 (2007): 377, 386; M. E. Badar, “Just Convict Everyone!” - Joint Perpetration: From Tadic to Stakic and Back Again", (2006) 6 International Criminal Law Review 293, at 302; Mark Drumbl, Atrocity, Punishment, and International Law, (West Nyack: Cambridge U.P., 2007), 39.
} 
outside of the scope of the original agreement, provided they were the foreseeable consequence of activities that were originally agreed upon or contemplated. Hence, the purpose of JCE is to facilitate convictions, as it significantly reduces the prosecutorial burden of proof, and permits the conviction of the morally-and objectively-innocent. ${ }^{520}$ I have argued elsewhere ${ }^{21}$ that JCE is both a very recent and unique legal concept. JCE is only deployed in cases where there is, in fact, no evidence-or insufficient evidence, from the standpoint of the criminal burden of proof-of genocidal intent. In other words, its purpose can be said to be to convict the innocent.

JCE is recent, as the ICTY's Statute does not-and did not at the institution's creation-include this "prosecutorial tool" as a mode of participation in a criminal offence ${ }^{22}$; indeed, Article 7 of the Statute sets out traditional modes of participation, which require evidence of both a criminal act, either as a direct act, or as alternate, traditionally known modes of participation, such as aiding and abetting, or a common agreement, plan or design as well as criminal intent.

Scharf's position, in contrast, is that JCE forms part of customary international law since the Nuremberg trials, and an impressive array of arguments are offered in support of this argument. However, precedents (such as the Eichmann trial) or the debatable inclusion of all Nuremberg principles into

\footnotetext{
520 See Hector Olasolo, "Joint Criminal Enterprise and its Extended Form," Criminal Law Forum (2009) 20:263-287, 284

${ }^{521}$ Tiphaine Dickson and Aleksandar Jokic, "See No Evil, Hear No Evil, Speak No Evil: The Unsightly Milosevic Case," International Journal for the Semiotics of Law 19, (4), 2006: 356. 522 JCE was introduced in the case of Prosecutor v. Brdjanin, Decision on Interlocatory Appeal, Appeals Chamber, IT-99-36-A, 19 March 2004, at paras 5-10.
} 
international criminal law do not appear to suffice; Scharf wants to make a different argument, and employ his concept of a Grotian moment to strengthen his legal case. This is done by arguing that the particular atrocities committed by the Nazi regime-described in a single paragraph that omits Germany's invasion of the Soviet Union, surely not a detail of history, and which footnotes two pages from a previous book written by Scharf himself as sole historical support-having led to the establishment of the Nuremberg tribunal, constituted a paradigmatic shift in law. Thus, (and this is Scharf's specific goal) JCE should apply to the defendants before the Cambodia tribunal, and constitutes evidence that this mode of participation was included in international criminal law in the nineteenseventies when the Khmer Rouge regime was in power.

The argument is troubling along legal and historical lines: the legal controversy has, in the case of Cambodia, been resolved by the Appeals Chamber, which has ruled that the most controversial form of JCE523 was not a mode of criminal participation in international criminal law during the years 1975 to 1979 . In fact, the Extraordinary Chambers in the Court of Cambodia, a hybrid international court, have rejected Scharf's arguments as legally unfounded. The Chambers also served a stunning rebuke to the ICTY Appeals Chamber decision in Tadic: the decision incredibly included an egregious error: a quote from Nuremberg prosecutor Telford Taylor's argument, presented by the ICTY Appeals

\footnotetext{
523 Public Decision on the Appeals Against the Co-Investigative Judges Order on Joint Criminal Enterprise (JCE), D97/15/9, 20 May 2010, Extraordinary Chambers in the Court of Cambodia. Kevin Jon Heller is unambiguous in his praise for this decision, claiming that the Tadic appeals decision of the ICTY created JCE III "literally out of thin air,"

http://opiniojuris.org/2010/o5/23/the-eccc-issues-a-landmark-decision-on-jce-iii/
} 
Chamber as part of the Einsatzgruppen judgment. This is the ICTY's final court of appeal, and Tadic was the ICTY's first judgment. Errors and unsuccessful legal arguments are the stuff of everyday practice and scholarship, but what is unusual in Scharf's approach is the blend of (poor) history and legal argument to create claims that would facilitate the conviction of the innocent. Misuse of history in legal scholarship ought to baffle the historian as much and arguably more than Ingram's Alice in Wonderland feeling when confronted with international relations theory, as work such as that written by Scharf is normative in nature, and in this particular instance militates for the conviction of the innocent based on some sort of historical-as opposed to a legal-idea of sudden paradigmatic shifts in international law, minus states ratifying treaties, or their opinio juris. A historian might wonder, as Ingram does about the democratic peace theory, why only the case of Nuremberg? Why no international courts during the cold war? Can the sudden change solely be explained by atrocities that re-emerged only in the nineteen-nineties? If Nuremberg, for the sake of argument, modified customary international law in a "Grotian moment," why is aggressiondescribed by the Nuremberg's Trial of the Major War Criminals as "the supreme international crime"-not presently an actual crime? Historians of legal bodies can also question Scharf's assertions that only the United States wished to tryrather than to execute-the Nazi leadership, whether Nuremberg was an international body rather than the exercise of jurisdiction by the Allies following German terms of surrender, whether conspiracy charges were an exclusively 
American idea, and whether following Nuremberg, international law could charge and prosecute individuals.

\section{The Dangers of Obiter Dicta}

In criminal law, what goes beyond the legal and factual findings required to find whether an individual is guilty or not guilty of an offense, before a court of law, is obiter dictum. 524 Similarly, international court practice disallows a determination in favor of parties that go beyond the issues of a case; this rule is known as non ultra petita. ${ }^{25}$ History written by an international court thus falls somewhere between obiter dicta and ultra petita, but this history is less the responsibility of the judges as it is attributable to the nature of these bodies, described by Judith Shklar as "law-like political institutions."

Since these courts are the product of international politics, they can fall within the scope of international relations scholarship. What should be borne in mind is that international war crimes courts exist at the intersection of politics, law, and history; they are not impervious to the influence of the media. This has an effect on both the history these courts can be expected to write and the fairness of the process.

524 Black's Law Dictionary, (8th edition, Eagan, West Group, 2004), 1102.

525 "It is the duty of the Court not only to reply to the questions as stated in the final submissions of the parties, but also to abstain from deciding points not included in those submissions" (Asylum, Judgment, I.C.J. Reports 1950, p. 402), reiterated by the International Court of Justice in Arrest Warrant of 11 April 2000. (Democratic Republic of the Congo v. Belgium), Judgment of 14 February 2002, par. 43. 
Historians, political scientists, and legal scholars all have a stake in the manner in which they examine the development of international criminal law: historians ought be wary of the history written by courts, and understand, along with legal scholars, that the process cannot be divorced from the political aspects and purposes of these bodies. Political scientists or philosophers, in turn, should not shy from the study of international criminal law as a political question and the establishment of war crimes tribunals as a result of power and of interests; indeed, they are well suited to address the limitations of international law, but they may have to approach the issues reflexively, ${ }^{526}$ rather than attempt empirical theory building and the generation of correlations focusing solely on behavior and ignoring purposive agency. The manner in which historians arrive at synoptic judgments about events, and the care with which evidence is treated should serve as a model for international relations scholarship.

Finally, in examining international criminal courts, international relations scholarship, and conceptually minded thinkers like philosophers, ought to pay attention to the quality of the history generated by these institutions and take great care to verify those narratives with the more careful and deliberate work of historians. International relations and international legal scholars and those who have an interest in evaluating their argumentation, however well intentioned they may be in hoping that a Grotian moment has emerged and that new, unwritten norms now govern individuals, would be well-advised to approach their hopes

\footnotetext{
${ }^{526}$ This has been proposed by Ido Oren, who adopts a Weberian, reflexive, and critical approach to political science in Our Enemies and US: America's Rivalries and the Making of Political Science, (Ithaca NY: Cornell University Press, 2003), 183.
} 
with caution: so-called Grotian moments today seem to operate to the detriment of individuals charged with grave crimes, and some innocent people may well pay the ultimate price of an unjust conviction.

Miscarriages of justice can occur internationally, and are more likely to do so in the misguided search for historical truth. In The Judge and the Historian, Carlo Ginzburg writes that: "in comparison with the errors of historians, however, the errors of judges have more immediate and more serious consequences. They can lead to the conviction of innocent people." 527 And now, at least in France, where Inquisitor Jacques Fournier once tried people for their beliefs, it is a crime to contest the obiter dicta of "law-like political bodies," a matter that ought to-and is-of great concern to historians. It should also be of concern to international legal theory and practice.

527 Ginzburg, The Judge and the Historian, 119. 


\section{Essay 4: Shklar's Legalism and the Liberal Paradox}

"And it is with some dismay that I now find myself treated as the purveyor of standard ideas, known to and accepted by all, even by the most conservative academic lawyers. To recognize that professions have their self-sustaining ideologies is hardly news today, but it was in 1964. And so Legalism, which is my favorite of the books that I have written, went quickly from being a radical outrage to being a conventional commonplace." ${ }_{528}$ -Judith Shklar, “A Life of Learning,” 1989.

\section{Legalism's Interdisciplinary Promise}

Judith Shklar’s 1964 book, Legalism: Law, Morals and Political Trials529 is an eclectic, sophisticated, erudite, critical, historical, but primarily political exploration of a phenomenon, legalism, that she defines immediately as "the ethical attitude that holds moral conduct to be a matter of rule following and moral relationships to consist of duties and rights determined by rules.” This early definition is misleading: what Shklar wanted to really get at was that legalism, or perhaps more accurately legalisms, plural, as she details several kinds, constitute ideology, by which she meant simply a political preference of a certain type. 530

This again is too simple a qualification, as legalism also stands for an evolving concept that shifts from an ideological attitude held by lawyers as a social group, to a potential "creative policy," then finally to a conservative and

\footnotetext{
${ }^{28}$ Judith Shklar, “A Life of Learning," Charles Homer Haskins Lecture for 1989, American Council of Learned Societies, Occasional Paper No. 9, 16.

529 Shklar, Legalism.

530 Ibid., 3-4.
} 
stabilizing force compatible with a wide range of other political ideologies. ${ }^{51}$ Most importantly, however, it is a historical phenomenon, which is why, writes Shklar, it cannot "be understood simply by defining it." 532

The concept, so far, is at once sociological (concerning practicing and academic lawyers), ideological, political, and historical. Legalism-let us for now simply define it as a culture of rule-following-is of course a feature of most democratic societies; in addition, it illustrates the sort of formality that is required if judicial bodies established internationally are to be considered legitimate, a critical requirement in absence of supranational enforcement mechanisms. Of particular interest in the context of the post-cold war institutions of international criminal law, Shklar identifies legalism as a specific and paradoxical ideology that denies "both the political provenance and the [political] import of judicial decisions." 533 That intuition is at the heart of my research agenda: how do bodies that exist as a result of international politics deny their politics? What are those politics, and is there a political and historical cost in denying them? The concept of legalism, as a specific ideology inherent in legal practice and scholarship that considers itself apolitical, neutral and independent-which happens to be the very source of its legal and political legitimacy - but that cannot in fact be dissociated from politics presents a rich conundrum. And because it is at root a historical phenomenon, it can be historicized. Because it relates to multivarious fields, it can be historicized across

\footnotetext{
531 Ibid., 112-220.

532 Ibid.,1.

533 Ibid., ix.
} 
many disciplines.

Legalism has a place of theoretical pride in Gary Jonathan Bass' Stay the Hand of Vengeance: The Politics of War Crimes Tribunals, a work that argues that liberal states are legalistic, and therefore are more likely to put war criminals on trial in rough accordance with their domestic norms than non-liberal states.534 The liberal/non-liberal distinction should be familiar to both the historian of nineteenth century history law and its emphasis on the distinctions between civilized and uncivilized states, as well as to the international relations scholar acquainted with the work of Anne-Marie Slaughter. An actual reading of Legalism, beyond the ritual, initial definition provided by Bass, proved to be an engagement with a much different phenomenon, as well as a different argument altogether, made immediately evident from reading her acid critique of the Nuremberg and Tokyo trials, or her trenchant indictment of the Rosenberg and Dennis trials in the United States. That Legalism was written by a liberal political theorist is no doubt true; that it was a sanguine defense of legalism and of political trials as carried out in liberal states is, in contrast, patently false on even the most tortured reading. The gap between the actual content of Shklar's argument and the purposes to which it was put by Bass is puzzling. Samuel Moyn has observed that Shklar's book had little impact at the time of its publication, hypothesizing that her having "dripped scorn" on most if not all legal academia of the time might have something to do with the cool reception, and that in any

534 Gary Jonathan Bass, Stay the Hand of Vengeance: The Politics of War Crimes Tribunals (Princeton, N.J.: Princeton University Press, 2000), 20. 
event legal realism may have superseded her arguments. 535 He adds that despite the fairly recent reemergence of international criminal law, "no one in the legal academy [...] has ever paid serious attention to it." ${ }^{36}$ This, though the "serious" part is true, does not mean that Legalism has not been swept up as an almost obligatory reference by a remarkable number of scholars. In 1989, three years before dying from massive heart failure, Shklar presented a lecture about her intellectual trajectory in which she wrote of Legalism that it was her favorite book, and that it was "with some dismay" that she found herself, after the book's initial reception as a "radical outrage," "treated as the purveyor of standard ideas, known to and accepted by all." 537 While Shklar could be dismayed at the signal year of the cold war's end that the initial controversy sparked by Legalism had fallen into the realm of conventional wisdom, its arguments fully understood and no longer subject to dispute by any serious academic lawyer or political philosopher, today, Shklar might be struck both by the renaissance as well as the uses to which Legalism has been put, precisely in theorizing the triumph of the very ideology she examined and critiqued.

Ubiquitous superficial footnotes citing Shklar employ the concept of legalism in many curious ways: it is meant to refer to approaches to international criminal law that favor judicial institutions, 538 or perhaps to be opposed to ad hoc

\footnotetext{
535 Samuel Moyn, “Judith Shklar versus the International Criminal Court," Humanity 4, no. 3 (2013): 473-500, 493.

536 Ibid.

537 Judith N. Shklar, A Life of Learning (American Council of Learned Societies, 1989), http://www.acls.org/uploadedFiles/Publications/OP/Haskins/1989_JudithNShklar.pdf., 16. ${ }_{538}$ Jack L. Snyder and Leslie Vinjamuri, "Trials and Errors: Principle and Pragmatism in Strategies of International Justice," International Security 28, no. 3 (n.d.): 5-44, 13.
} 
courts.539 Legalism is instead the mistaken view that international collective action problems can be solved through recourse to institutions that are unrealistic, ineffective, and ignore interests as well as their potential for rational attainment.540 Maybe arguments in Shklar's Legalism should stand for the proposition that political trials are valuable to establish a historical record and prevent revisionist accounts, or the claim that to focus on due process and individual culpability is "too narrow" in the context of international criminal law. ${ }^{411}$ Some have even shown tremendous political creativity in purporting to continue and expand on her work, offering a full-throated defense of liberal show trials.542 It is difficult, if not impossible, to find the streamlined, or worse yet, disfigured “legalism” before Bass' significant mention of Shklar's work in 2000.

Thus, the historical development of Shklar's legalism - not to be confused with the idea of law generally-is revealing. It is apparent that the renewed reference to the work emerges after being cited by Bass as a general defense of the Western, liberal-and it is not going too far to say distinctly American-war crimes trial, but that the totemic footnotes do not imply serious engagement. Instead, what is observable is rather a historical coincidence of the emergence of ad hoc and hybrid international courts, as well as the development of the International Criminal Court, and the publication of an influential book by a

\footnotetext{
539 John M. Czarnetzky and Ronald J. Rychlak, "Empire of Law: Legalism and the International Criminal Court, An,” Notre Dame Law Review 79 (2004 2003): 55.

$54^{\circ}$ Eric A Posner, The Perils of Global Legalism (Chicago: University of Chicago Press, 2009), 19. ${ }^{541}$ Jenia Iontcheva Turner, "Defense Perspectives on Law and Politics in International Criminal Trials," Virginia Journal of International Law 48, no. 3 (2008): 529-594, 535, 539. 542 Mark Osiel in Guénaël Mettraux, Perspectives on the Nuremberg Trial (Oxford; New York: Oxford University Press, 2008), 704.
} 
Princeton rising star (and former journalist) who had himself to some extent jumped on the bandwagon of the successful liberal international relations theory with what "sometimes appears as if a theoretical introduction and conclusion were heaped on what was a lot of-otherwise good-journalism.”543

Shklar's first charge against legalism is that it walls itself off from the rest of historical thought and experience. Law's (or more properly legal theory) propensity to isolate itself from other social phenomena, to limit history to its own discrete jurisprudence, to seal itself off from politics and morality, is primarily what makes it an ideology. For legalists, law is "there" to be discovered and properly interpreted and exists, in its own conception, outside historical space and time. It is a phenomenon, at least in the history of ideas, that can be historicized: contemporary lawyers, Shklar contends, resemble Coke in "their vocabulary, outlook and concerns," something that cannot be said of medical doctors in relation to their respective pre-nineteenth century predecessors. De Tocqueville, she contends, describes perfectly well the modern lawyer's conservatism, built on dedication to order and formality, which translates into support for the established social order. Thus, the radical village lawyer of the French Revolution "was an aberration that the aristocracy foolishly brought upon itself."544 A hundred years later, she sees continuity in Max Weber's assessment of the conservative bureaucratic lawyer, but points to the "liberalizing effects of involuntary politicization on the American higher bench, doomed to interpret

\footnotetext{
543 Frédéric Mégret, “The Politics of International Criminal Justice," European Journal of International Law 13, no. 5 (2002): 1261-84, 1268. 544 Shklar, Legalism, 14-15.
} 
and adapt its own constitution" as historical evidence to support the theoretical claim that legalism should be seen as a matter of degree, rather than as either "there" or not "there" as lawyers think, Shklar states, of the law.545

Shklar is not alone in historicizing legalism: where she sees de Tocqueville's aristocratic habits of thought in the bench and bar as less accurate than Weber's distinction between class and the specific sociological mores of lawyers as responsible for their propensity for order, noting, in addition, that the law, in America, then as now, was open to talent, "the poor boy's road to middle class eminence," ${ }^{546}$ Eric Posner speculates that American legalism may be a symptom, paradoxically, of a skeptical view towards democracy and a veiled preference towards the rule of judges. 547 Posner further conjectures that legalism holds sway in polities where the population is more diverse, and political means of resolving disputes are less available or viewed as unable to successfully navigate bargaining between disparate groups. Many empires with diverse populations, he offers, citing the examples of the Roman, Austro-Hungarian and British Empires, have been legalistic. ${ }^{548}$ In more recent American history, Posner argues, courts with their inherited authority from the British system, presented a desirable alternative to a weak, remote national government, as well as state legislatures viewed with distrust. Finally, for Posner, de Tocqueville's observation that in America the law functioned as a benign aristocracy ought to be sharpened: that elites prefer judges to democracy should be taken to stand for a stronger

\footnotetext{
545 Ibid, 15.

546 Ibid, 16.

547 Posner, The Perils of Global Legalism, 22.

548 Ibid, 21.
} 
anti-democratic preference, and a defense of class interests.549

Mark Mazower's study of international governance illustrates similar nineteenth century themes: as European groups, assorted entities, and even states joined efforts to attempt a legal global governance-even the term "international" is a pure product of the century, coined by Jeremy Bentham550time and again, legalism took a conservative turn. From the idealism that first motivated great initiatives for world peace, the shift to law created a first wave of disappointment in Kant-his bitter reference to the "miserable comforters" Grotius, Pufendorf, Vattel "and the rest," for their justifications in favor of war speaks volumes551 - but by the late nineteenth century advocates of international law, by Mazower's account, seemed increasingly anti-democratic; they denounced socialism and anarchism, drafted extradition treaties for political crimes, and used the law as a rationalization for plunder abroad, while claiming that justice was on their side. $5^{22}$ Shklar firmly attached the cold war idea of a "Western political tradition" to the rule of law, but traced the felt need for ideological identity of the time to nineteenth-century claims of European "rationality." Weber's comparisons of the distinguishing features of European culture-its propensity to follow rules, responsible for the legal profession, capitalism, rational social ethics, and finally, Protestantism-to "Eastern despotism," are historically problematic for Shklar. Beyond questioning the

\footnotetext{
549 Ibid, 22.

$55^{\circ}$ Mark Mazower, Governing the World: The History of an Idea (Penguin Press HC, The, 2012), 19-20.

${ }^{551}$ Immanuel Kant, Kant: Political Writings, ed. H. S. Reiss, trans. H. B. Nisbet, 2nd ed. (Cambridge University Press, 1991), 103. $55^{2}$ Mazower, Governing the World, 80.
} 
adequacy of Weber's account of Asian history, the problem was that there was no single Western tradition, but rather a history of traditions, a diversity of conditions that accounted for Europe's turbulent history. To state, writes Shklar, that "freedom under law" characterizes the Western tradition "falsifies the past, and renders the present incomprehensible." 553 Legalism thus serves as a critical concept that invites historical investigation, or at least awareness, and stands against "the idol of origins," 554 specifically the temptation to view the very new post-cold war international criminal courts as a result of continuous progress, in the manner of a Whig history555 that international law has always advanced, and will continue its march of progress.

Following Shklar, as well as Morgenthau, I contend that international law is a subset of international politics, and in the international relations aspect of my interdisciplinary work, I am interested in the normative implications of the denial of those politics. Courts such as the ICTY and ICTR, and now the ICC are historical agents, who also happen to write history556 but insist, for the sake of their legalistic legitimacy, on the denial of the historical conditions that granted them their limited autonomy557 in particular on the dimension of power. Shklar's normative view of political trials is not that they are inherently anti-democratic, or even totalitarian; instead, she contends that the kind of politics they pursue-

\footnotetext{
553 Shklar, Legalism, 22.

554 Samuel Moyn, The Last Utopia: Human Rights in History, Reprint (Belknap Press, 2012), 4041; Marc Bloch, The Historian's Craft (Manchester University Press, 1992), chapter 1.

555 Posner, The Perils of Global Legalism, 25.

${ }_{556}$ Richard Wilson, Writing History in International Criminal Trials (Cambridge; New York: Cambridge University Press, 2011).

557 Yves Dezalay and Mikael Rask Madsen, "The Force of Law and Lawyers: Pierre Bourdieu and the Reflexive Sociology of Law," Annual Review of Law and Social Science 8, no. 1 (2012): 433$52,436$.
} 
and not whether or not they are political-ought to be the object of the inquiry. It is the nature of the politics that are assessed, and political trials can be excused, tolerated, even encouraged if the politics they promote are "decent." Conversely, and quite contrary to the use that Bass and others have made of this concept, legalism alone is not enough for decent politics, as a rule of law system can have repressive rules and fanatical judges, producing "neither freedom nor decency." ${ }^{5} 8$ Decency, pursues Shklar, is "the spirit of humane skepticism." While disconcertingly brief, Shklar's idea of decency as humane skepticism can provide some guidance and is certainly both sufficiently expansive but fundamentally critical to assess the international politics of criminal trials. In this essay, I develop a working lawyer's legalism that examines precisely the humane skepticism and the promotion of central tenets of classical liberalism, such as the values of human autonomy, freedom and equality, in the nature of the work of defense lawyers generally, and those practicing before international courts in particular.

Legalism's connection to the phenomenon of Memory Studies is a fascinating question on its own. Memory Studies or what I prefer to more broadly call Memory discourse - whatever it may actually be, so varied are the methodologies that sometimes simultaneously drive and study it559-emerged much at the same time as the renewed interest in Shklar's legalism, interest in the Holocaust, which played an important analogical role in the establishment of a

$5^{58}$ Shklar, Legalism, 209.

559 Richard Crownshaw and Jane Kilby, The Future of Memory (New York: Berghahn Books, 2010). 
first ad hoc criminal court as well as the re-emergence of international criminal law.

Historian Peter Novick invoked Maurice Halbwachs' concept of collective memory to provide part of the theoretical framework for The Holocaust in American Life, 560 but only briefly summarized Halbwachs' work as focusing on "the way in which present concerns determine what of the past we remember," then pit this slight definition of collective memory against history: memory is then ahistorical, even anti-historical, sees events from a single committed perspective, is impatient with ambiguities, and reduces events to mythical archetypes, while history, in contrast, strives to grasp the complexity of past events with the kind of detachment that would permit an interpretation that allows various perspectives as well as their inherent ambiguity. ${ }^{61}$

Such a functional definition of history and memory by contrast is reminiscent of Pierre Nora's similar exercise in Les lieux de mémoire, though normative preferences differ in their respective accounts. "Memory is life," writes Nora, while explicitly recognizing (and here the epistemic position differs little from that adopted by Novick) that memory, as a phenomenon borne by living societies, is vulnerable to manipulation, appropriation, censorship and projection. Nora's account, in contrast to Novick's, depicts history as a discipline whose mission is to "destroy and suppress memory" even to "annihilate what in

560 Peter Novick, The Holocaust in American Life (Boston: Houghton Mifflin, 2000), 3-4. 561 Ibid. 
reality has taken place.”562

Leaving aside for the moment the question of whether historicizing memory would end up, following Nora, cannibalizing it altogether, memory has in many ways become increasingly legalistic. "Legalism" here should not be understood as a rule-governed conduct exclusively, but rather as a framework of representation. A significant example of what I mean here is the explosion, in the past few decades of "the imperative of witnessing" "as a powerful secular norm." ${ }^{663}$

Legalism, a nuanced critical concept with normative implications, holds the tremendous interdisciplinary potential to help achieve what Martti Koskiennemi has called for in international legal history, that is "to contextualize the legal ideologies or concepts within the intellectual, social, and political environment in which they have operated." 564

Shklar and the Nouveaux Legalists

While the late political philosopher Judith Shklar could be dismayed in 1989 that the initial controversy sparked by Legalism had fallen into the realm of conventional wisdom, its arguments fully understood and no longer subject to

\footnotetext{
562 Pierre Nora, "Between History and Memory: Les Lieux de Mémoire" Representations (trans. Marc Roudebush), Spring 1989, 26: 7-25, 8-9. 563 Samuel Moyn in Dan Stone, The Holocaust and Historical Methodology (Oxford: Berghahn Books, 2012), 127. 564 Martti Koskenniemi, The Gentle Civilizer of Nations: The Rise and Fall of International Law 1870-196o (Cambridge University Press, 2004), 65; Skouteris in Justo Corti Varela et al., New Approaches to International Law : The European and the American Experiences, 1st ed. (Dordrecht: Springer, 2012), 118.
} 
dispute by any serious academic lawyer or political philosopher, today, Shklar might be struck both by the renaissance as well as the uses to which Legalism has been put, precisely in theorizing the triumph, following the end of the cold war, of the very ideology she examined and critiqued: legalism. Moreover, from the commonplace that it may or may not have been two decades ago, the concept of legalism - which far from being the simple notion that "professions have their self-sustaining ideologies," though it is indeed an important and not unsubstantial insight, and in the case of lawyers, not without certain special difficulties, to which we shall return-has reemerged as something so streamlined and arguably trivial as to bear very little resemblance to the complex exploration undertaken by Shklar in 1964. The "new," primarily post cold war legalism is an ubiquitous footnote in many ambitious articles and books, and is particularly favored by scholars concerned with international criminal law; however, few of these authors appear to have engaged Shklar's work on the concept in earnest. For to engage with Legalism is to be confronted with an evolving concept that shifts from an ideological attitude held by lawyers to a potential "creative policy," 565 then finally to a conservative and stabilizing force compatible with a wide range of other political ideologies. 566 There is, of course, much more to it, and in some cases there is not only more, but something different altogether; thus, rather than refer unthinkingly to an unexamined concept, or worse, perhaps, to embark upon a critical analysis of it without first having given thought and due respect to the manner in which Shklar develops and modifies it

565 Shklar, Legalism, (Cambridge: Harvard University Press, 1964) 112. 566 Ibid., 220. 
herself, it is advisable to give Legalism a second look.

Legalism is a feature of most democratic societies, but can in addition constitute an ideology that denies "both the political provenance and the [political] import of judicial decisions." 567 Legalism illustrates the sort of formality that is required if judicial bodies established internationally are to be considered legitimate, a critical requirement in absence of supranational enforcement mechanisms.

It is worth noting that legalism is both a tool of critical political analysis and a concept that has been reinterpreted by subsequent scholars and publicists as representing formalism as well as a distinctively liberal virtue.568 Reviews published following the initial appearance of Legalism certainly did not mistake Shklar's argument as its opposite, as seems to have occurred in recent years. The problem of legalism as a scholarly attitude unattuned to the political significance of law's social role was then greeted with philosophical skepticism-a contribution to the Philosophical Review dismissed Shklar's views as "not, even on the most latitudinarian construction, those of a philosopher," 569 and another, written by Tokyo prosecutor Joseph Keenan's occasional co-author, Brendan Brown, accused Shklar of engaging in moral relativism, and failing to distinguish human dignity from that of a baboon. ${ }^{570}$ There was, as well, the occasional

${ }^{567}$ Shklar, Legalism, ix; Shiraz Dossa, "Legal Liberalism: Law, Culture and Identity", The European Legacy, 4 (1999): 73-89, 76.\{Citation\}

${ }_{568}$ Bass, Stay the Hand of Justice, 6.

${ }^{569}$ H. A. Bedau, "Review," The Philosophical Review, 76, (1) (Jan., 1967), 129-130.

570 Brendan F. Brown, "Review," The University of Toronto Law Journal, 17, (1) (1967), 218-225, 220. 
expression of praise for having raised an important albeit difficult political and philosophical question. ${ }^{571}$ Shklar's characteristic queasiness with absolutes 572 was already apparent in her 1964 analysis of law, politics, and political trials. She was skeptical of the utopias she grappled with early on in her career, 573 but beyond the more obvious kinds of political extremes typically derided in the cold war context, Shklar was also critical of the "Athens-worship" for which she faulted Hannah Arendt,574 and unimpressed with her friend Michael Walzer's idealization of communities and informal interest groups, 575 views she found to be perfectly consistent with intolerance, injustice, and indeed cruelty. It is precisely her dispositional skepticism, as well as her meticulous care to read and convey with unusual charity her sources that make Shklar's work so complex and valuable, but at the same time challenging for the reader, who is inspired to consider her arguments with commensurate care. Though Legalism's erudite inquiry into the manner in which the legal field attempts to insulate itself from politics and struggles with morals proved to be provocative, it did not stand for a crude triumphalism of Western, liberal justice.

Shklar's skepticism is key to understanding her approach to the problem of legalism. Self-described as a natural, painless skeptic, Shklar found that Rousseau, who she credited for providing her with both "political imagination and a second education," expressed a revealing discomfort with doubt. She

\footnotetext{
${ }^{571}$ Francis R. Aumann, "Review,” The Journal of Politics, 27, (3) (Aug., 1965), 703-705. 572 James Miller, "Pyrrhonic Liberalism," Political Theory, 28, (6) (Dec., 2000), pp. 810-821, 814. 573 Judith Shklar, After Utopia (Princeton, NJ: Princeton University Press, 1957) 574Judith Shklar, "Hannah Arendt as Pariah," Political Thought and Political Thinkers, Stanley Hoffmann, ed., (Chicago: University of Chicago Press, 1998), 362, 369. 575 Ibid., "The Work of Michael Walzer," 376, 381.
} 
preferred the skepticism and indeed the legalistic protection of individual autonomy defended by Montesquieu. ${ }^{576}$ What was seemingly a "continuing revelation" in Rousseau's struggle with skepticism was the contrast presented by Montesquieu: classical liberalism, as Shklar conceived of it, required a decent dose of doubting, an "unconventional view," as she defined skepticism in the late 1980s, "of accepted social beliefs." 577 But skepticism, for Shklar, is more than that; it is an epistemic reaction to disastrous events in human history that leads to question what we know, and how we can know it, demanded by the failure of knowledge to avert the human catastrophes of war and extreme suffering. Not to be confused with the pyrrhonism against which she cautioned postEnlightenment historians, ${ }^{578}$ and with which she generally had little patience, 579 this skepticism is intimately related to Shklar's inquiry into the legalistic ethos, as it is explicitly doubts, in the post war context, "the moral relevance of the normal system of justice." 580

"The great skeptics," observed Shklar in her discussion of the idea of injustice in the works of Plato, Cicero, St. Augustine and Montaigne, "doubted that law-governed judgments could achieve their aims, because we simply cannot

\footnotetext{
576 Judith Shklar, “A Life of Learning," Charles Homer Haskins Lecture for 1989, American Council of Learned Societies, Occasional Paper No. 9, 16-17.

577 Judith Shklar, “Giving Injustice Its Due” Yale Law Journal Vol 98 no 6, 1989, 1135-1151, 1137. 578 Judith Shklar, "Learning Without Knowing," in Political

Thought and Political Thinkers, ed. Stanley Hoffmann, (Chicago: University of Chicago Press, 1998) 105-131, 106.

579 Bernard Yack, "Liberalism Without Illusions: An Introduction to Judith Shklar's Political Thought" in Judith Shklar and Bernard Yack, Liberalism Without Illusions, (Chicago: University of Chicago Press, 1996), 11-12.

580 Ibid.
} 
know enough about men or events to fulfill the demands of justice." 581 The burden of history thus leads to the necessary acknowledgement of the modesty with which skeptics must view the sources of law and practices of the judiciary. There is more, and worse. Alongside Montaigne, with whose Essays Shklar began engaging in earnest when examining the myths and illusions of American history and political thought, ${ }^{582}$ Shklar explored the contention that trusting rules could make us too sure, arrogant, even cruel and tyrannical; that beyond the failure of what she called "normal justice" to achieve justice, it could actually promote harshness and social sclerosis by being delusionally overconfident in its abilities. 583

The critical discussion of legalism did not begin with Shklar; Hans Morgenthau's 1946 Scientific Man and Power Politics raises the liberal lawyer's blind faith in the normative superiority of her profession, and the naïve extension of the success of domestic law, in particular American law, in providing order to the sphere of international relations, the result of an "orgy of idealism." 584 For Morgenthau, this view was inherently liberal, a reflection of the Enlightenment's quest for the universal axiom, which among academic lawyers, was amplified by the belief that international litigation and legislation could serve-and better than any other means, as it indubitably had domestically-the cause of peace. That those other means meant primarily the messy business of politics-something to

\footnotetext{
581 Ibid.

582 Life of Learning, 20

583 “Giving Injustice Its Due," 140-141.

584 Hans Morgenthau, Scientific Man and Power Politics, (Chicago: University of Chicago Press, 1946) 111, quoting Max Lerner.
} 
be obviated entirely by the legalists' attempts to render international conflict rational and calculable-was a fundamental, though unacknowledged insight in Shklar's legalism. For her, as for Morgenthau, the idea that politics would somehow be inferior to law, rather than the area of human relations of which law is a subset, was not only delusional in that it was grossly inaccurate, but actually deleterious, in that wholesale reliance on something as fragile as international law, to be enforced by something as vague as the international community-the existence of which Shklar stoutly denied585-and on its "spurious analogies" of "dueness" and punishment, could not lead to peace. Morgenthau was far more direct in his critique of the influence of legalism on foreign relations. "For here," he wrote, referring to states' inability to learn the lessons of 1914, "our first appeal is always to the law and to the lawyer, and since the questions which the law and the lawyer can answer are largely irrelevant to the fundamental issues of which the peace and welfare of nations depend, our last appeal is always to the general." 586 The 2011 misguided military intervention in Libya, meant to enforce the novel international legal doctrine of "responsibility to protect," hardly proves Morgenthau incorrect on that count.

Shklar's only acknowledgement of Morgenthau is to classify him among the realists who commit in her view the related ideological error of insisting that history, politics, morality and law be confined to separate and isolated spheres. Furthermore, Shklar, though finding the realists' rejection of legalism "sensible

\footnotetext{
585 Shklar, Legalism, 156-157: “...there was and is no system of international criminal law, just as there are no international community and no international political institutions to formulate or regularly enforce criminal laws." 586 Morgenthau, Scientific Man and Power Politics, 121.
} 
enough," ${ }^{87}$ considers nonetheless that their project is ideological, first for their reliance on the "national interest" as something that can be discerned, calculated, and obeyed; and second as a result of the realist dislike for liberalism, "largely because the latter failed." ${ }^{8} 88$ Shklar's insight regarding the conceit of calculability strikingly presents a mirror image of Morgenthau's critique of liberal legalism. Shklar details how realism's hostility to hypocrisy led to the search for a pure politics, and cites in particular Carl Schmitt's conception of power as a unique and separate phenomenon. This political pedigree could hardly be further from the work of the classical realists Shklar was discussing, among whom was George Kennan, also not particularly known for any interest in the work of the Nazis' “crown jurist." And much like Shklar, Morgenthau expressed a clear objection to Schmitt's unmooring of politics from the moral order, which in its logical extreme invited the pure politics that could discard the totality of Western thought and lead to German fascist brutality. ${ }^{589}$ Not all realists, then, should be understood as Schmittian separationists.

Shklar nonetheless drew a prescient connection, as critical legal scholarship far to the left on the political spectrum of Schmitt's fascist leanings has reengaged Schmitt's work of late. 590 So, too has E.H. Carr's very similar

\footnotetext{
587 Shklar, Legalism, 124.

588 Ibid.

589 William Scheuerman, "Was Morgenthau a Realist? Revisiting Scientific Man vs. Power Politics," Constellations 14 (4) 2007, 506-530, 510

590 David Chandler, "The Revival of Carl Schmitt in International Relations: The Last Refuge of Critical Theorists?,” Millennium: Journal of International Studies Vol.37 No.1, pp. 27-48; Paul W. Kahn, Political Theology, (New York: Columbia University Press, 2011).
} 
critique of international law found its way into critical legal scholarship. ${ }^{591}$ Shklar acknowledges that the classical realists of her period are anything but fascists. They are, rather, she writes, "despairing liberals all." 592 In the case of Morgenthau, she might have added that they were despairing-or at least justifiably disappointed-legalists, as well.

The problem of legalism is not merely, however, a problem of the all or nothing thinking of the type Shklar attributes to lawyers. While it is fair to point out that legal theory has devoted what may seem for the political theorist to be an inordinate amount of intellectual resources to establishing the criteria that would determine whether a true system of justice exists-perhaps best illustrated by the passion and acrimony generated by the storied positivist/natural law debate between H.L. Hart and Lon Fuller, skillfully analyzed by Shklar593 though her analysis was deemed "caricatural" by at least one contemporaneous reviewer594the existence or not of law, a debate that Shklar rightly pointed out was unnecessarily artificial and did not serve in any meaningful way the social concerns that such theories purport to deal with,595 is really not the main problem occupying working lawyers or informed legal observers today. Legalism does indeed unnecessarily narrow the study of legal theory and empty it of its political content, but contemporary legalism is best understood when distinctions

\footnotetext{
${ }^{591}$ Nikolas M. Rajkovic, “'Global law' and Governmentality: Reconceptualizing the 'Rule of Law' as Rule ‘Through' Law,” European Journal of International Relations, 20 (10),(2010) 1-24. 592 Legalism, 125. 593 Legalism, 107-110.

594 H. A. Bedau, "Review," The Philosophical Review, 76, (1) (Jan., 1967), 129-130, 130. 595 The point is also made approvingly by Francis Aumann, in one of the rare positive reviews of Legalism immediately following its publication: Francis R. Aumann, "Review," The Journal of Politics, 27 (3) (Aug., 1965), 703-705, 705.
} 
are drawn between domestic law and its international counterpart. Law's power over the American imagination and political identity hardly requires belaboring; noticed early on by Tocqueville596 and today provocatively framed by some as a form of religious observance for the foundational document that is the United States' constitution, the idea of law looms large in the American liberal imagination.

\section{Legalism in the Trenches}

Whether the idea of law in America is theological rather than institutional or political, or merely a matter of habit is beside the point when the focus is shifted to international law. To debate the "thereness" of law in a domestic liberal jurisdiction can indeed be seen as a politically absurd pastime: it is very much there, inasmuch as "there" assumes an institutional framework, enforcement, and above all, the political legitimacy that ensures precisely the type of equal treatment and universal application, or at least its legitimate expectation, that liberals consider the law to embody, at minimum. In domestic law, despite the system's failure to always live up to this ideal-and it is readily identified as an ideal inasmuch as a society is scandalized in those relatively rare instances that it demonstrates its shortcomings-democratic institutions and law seek nonetheless to attain it. The situation in international law stands in stark

\footnotetext{
596 "The spirit of the law, born within schools and courts, spreads little by little beyond them; it infiltrates through society right down to the lowest ranks, till finally the whole people have contracted some of the ways and tastes of a magistrate." Alexis de Tocqueville, Democracy in America 270 (J.P. Mayer ed., George Laurence trans., Anchor Books 1969) (1840).
} 
contrast. There the liberal view, already complex and not always subject to perfect consensus over meaning or exact commitments, is not reflected in judicial institutions that, as the liberal view of justice requires, would hold all states equally to the same standards and obligations, under some kind of penalty meted out in proportion to an offence, and nothing else. This very basic, indeed crude idea of law, as demanding equal subjection, application, and enforcement, is a political one, and its politics are undeniably liberal. Viewed in this manner, to say that an international "law-like body" is illegal, that its legality is dubious, or as Shklar would have it, "not there," is in fact a political claim: it states that an institution is not legal in the sense that it does not possess the minimal attributes of justice on a liberal account. This is most evident in criminal law, where the political commitment to freedom, to be subordinated only to a rational, predetermined procedure, and only following the commission of an offence ostensibly to some principle critical to the maintenance of civil society, takes on the harder and more formal attributes of legalism. Yet the value of freedomfrom which flows the principle of legality and the presumption of innocence-is at root a political concept. Shklar makes much of lawyers' purported obliviousness to politics, but she ignores the fact that working lawyers-no doubt to be distinguished from legal theorists-are the artisans of applied political theory, whether they are aware of it or not.597 When the basic principles that permit working lawyers to carry out their function such as the presumption of innocence

\footnotetext{
597 For the opposite view of the distinction between the manner in which lawyers, on the one hand, and theorists, on the other, approach the idea of law, see Terry Nardin, "Theorising the International Rule of Law,” Review of International Studies (2008), 34, 385-401, 386. In Nardin's view, lawyers employ the law in a merely instrumental manner, while theorists seek to grasp its essence, and ask general, ontological questions.
} 
or the other safeguards to freedom that flow from it are not there, lawyers will point to illegality, and not to the absence of "decent politics." That is a result of their training, or their ideological legalism perhaps, but it is worth mentioning that in such a case what is being complained of is less a deficiency in the "thereness" of the law than the fact that some kind of body has the power to deprive individuals of freedom: if it can do that, then for the lawyer it is "there" enough to worry about. If it can do so without observing those formalized rules that emerged from political norms concerning individual freedom, the working lawyer's objection is in itself a defense of decent politics, as Shklar understood them. The very barebones liberalism of fear developed by Shklar has the rule of law as its first principle, and she observes that one half of the Bill of Rights is about fair trials and the protection of the defendant in a political trial, adding that without these protections "no one has a chance." 598

Thus, it seems legitimate for Morgenthau and Shklar to caution against the enthusiastic precipitation to adopt international legal institutions, as if their legality (or legalist trappings) could ipso facto succeed in guaranteeing order and peace all the while protecting liberty, as understood by the liberal forms of justice, as in domestic law. The critique of lawyers' objections to the illegality of international bodies or the irregularity of their proceedings, however, undercuts something very crucial in the liberal commitment to freedom. When Shklar formulates the creative potential of legalism as one that can promote decent politics, it is surely worth trying to distinguish between a politically decent 
political system, and whether an individual's freedom can be, in a wholly sui generis manner, subordinated to decent politics, whatever, in passing, those might actually consist of. If it is somehow conservative and a defense of the status quo for lawyers to understand "decent politics" to mean some recognized legal procedure that does not sacrifice an individual's liberty for whatever pedagogical purpose, no matter how grand, so be it. However, in practice, and certainly in criminal law, it is the hue and cry of the mob for the blood the designated transgressor that has always represented conservatism, and reflected precisely the kind of action fuelled by fear that Shklar found elsewhere the most deleterious to the tolerance demanded of liberalism.599 And it is the defense lawyers' principled refusal to permit mob rule-whether within or without legalistic support-at times invoking an established rule, and therefore arguably relying on the status quo-but more often seeking more humane interpretations of rules, on the basis of supralegal, be they constitutional or jurisprudential principles that any student of politics would recognize as political and philosophers as moral in nature. Working lawyers are thus very much alert to politics and to morality; that they invoke these principles in legal terms may have less to do with their ideological paralysis than the nature of the institutions in which they participate. The problem of "thereness," for working lawyers, then, is radically different from that which occupies academics: "thereness" for a defense attorney is established by the legitimate use of handcuffs and a potential sentence of imprisonment for a client. For this actor of international justice, hearing that a

599 Ibid., see, too, Corey Robin, Fear: The History of a Political Idea, (New York: Oxford University Press, 2004) 145-147. 
law-like body is perfectly legal and not at all political will either create expectations of commensurate due process, or will generate opposition and outrage if in fact the body demonstrates a primary commitment to international politics promoting the interests of powerful states. Does this show a kind of rigidity in lawyers, and does it prove that legalism is indeed a narrow-minded, conservative ideology, bent at all costs on preserving the status quo? What of the "decent politics" that political trials can accommodate? As for the lawyers, untrained as political actors, in particular when they are expected to play the role of the jurist in a legal trial when what it really at stake is an exercise in political pedagogy or an experiment in international relations, decent politics generally ought not employ them as pawns in another exercise altogether. Once the body, the charter, or the covenant is promulgated and established, it is unfair to the lawyer to blame her for assuming that it is indeed "there." And once it is there, for a lawyer, it means-and this, too, is a manifestation of legalism-that a norm is inevitably created that guarantees equality and supersedes power. ${ }^{600}$ Hence, the traditional distinction between, for instance, recourse to the Security Council, and an appeal to the International Court of Justice, where no great power veto exists. ${ }^{601}$ The expectation is precisely that politics will not intrude upon the settlement of a legal question, and that if it must, as any lawyer with any experience knows that it inevitably will on occasion, it will not be dispositive of the issue at hand. That type of result will be deemed illegal-contrary to law-but

\footnotetext{
${ }^{600}$ See Paul W. Kahn, "American Hegemony And International Law: Speaking Law To Power: Popular Sovereignty, Human Rights, And The New International Order," 1 (1) Chicago Journal of International Law, 2000, 1, 5 . 601 Ibid.
} 
also politically defective.

Working international criminal lawyers may demonstrate some naïve nostalgia for the pristine, apolitical justice of their domestic jurisdictions, understandably forgetting in the midst of trials meant to pursue liberal ideals that often end up doing so in illiberal ways, that their own municipal law often strains liberal principles. What seems different, as observed in Darryl Robinson's excellent analysis of international criminal law's struggle with its Jeckyll and Hyde relationship to liberalism, is that when what we can loosely call liberal states legislate in ways that do violence to those liberal principles that Shklar includes in the most minimal conception of legalism, as they have in the post September $11^{\text {th }}$ world, these changes do not occur without objection, debate, and the sense that something has been sacrificed. ${ }^{602}$ In other words, at home, it is clear that something has been lost. In international trials, that sense of loss is harder to come by. The attempt to deny and obviate politics is so actively pursued by international courts that the political understanding of sacrifice, however intuitive in a domestic jurisdiction, is often foreclosed, or denied.

This is what might be deemed a form of organic legalism, one that posits that inherent in the nature of any liberal understanding of law is the fundamental understanding that issues between parties will not be resolved by politics, but solely upon evaluation of the evidence and in accordance with rules of evidence, procedure, and pursuant to the law. For working lawyers it is simply impossible

602 Darryl Robinson (2008). The Identity Crisis of International Criminal Law. Leiden Journal of International Law, 21, 925-963, 930. 
to perform any professional duty outside this type of understanding; indeed, unless a trial is explicitly acknowledged as being political, a lawyer attempting to engage in "political," or extra-legal advocacy will cause a disservice to her client's interests, risk being shunned by her peers for having violated professional norms, and no longer enjoy the reputation of being a "normal" lawyer. Political advocacy in effect removes the lawyer from the realm of what is understood to be his function.

Shklar's legalism, when viewed as a conservative inability to think of law as a subset of politics within a nuanced continuum of political value, puts lawyers in a bind. Of course lawyers conceive of politics, whether in the legislative process or in the political leanings of prosecutors and judges. But it is a concern, and not an embrace, and in this respect Shklar is correct to pinpoint legalism as, if not an ideology, at least a mindset that does in the context of the law itself, privilege rule following to what is indeed the messy business of politics.

That kind of legalism is simply that of legitimate expectations. Lawyers deploy their trade in courts, and courts, in turn, are meant to eschew the political. That is what makes them courts. But another form of legalism, that which internationally, in particular, insists on its pure, unmitigated legal provenance, procedure, objectives and form, when in fact its creation and objectives cannot be considered purely judicial-for example because it is created by the Security Council of the United Nations, like the ad hoc courts for the former Yugoslavia and Rwanda, or because not all states accept to hold their nationals subject to the body, such as in the case of the International Criminal Court-deserve scrutiny 
here. Shklar may not have envisaged these types of bodies in her examination of legalism as a creative force in the service of decent politics and the elimination of bellicose expansionism and fascism through law. What seems to be the object of some consensus, however, is that bodies such as these do insist on their legality; advocates and opponents alike of the international criminal legal agenda point to the ICC's "legalism" and sometimes to its quintessential legalism. That insistence on perfect legality in cases where politics are evident (and often not denied by anyone except individuals acting within the tribunal setting and some engagé academics) is the legalism that today deserves examination. Why, indeed, is it essential to claim that international tribunals maintain an absolute absence of politics when these are evident, both from the very nature of international relations and by the purposes of the bodies themselves? And why, if the promulgation of decent politics is nothing to be ashamed of, should those ostensibly valid political objectives be shielded from view by those most actively participating in their enforcement? It may be that judges, tribunal administrators, and international prosecutors are as blind to politics as those academic lawyers Shklar chided in Legalism. This, however, though perhaps correct in some cases, seems unlikely as a general claim. What appears as a more plausible alternative is that Shklar's attempt to provoke the legal community into acknowledging the limits of the law and the reality of politics in the judicial realm failed in a spectacular manner; that law remains, as is the epitome of certainly the American character, as fetichized and glorified as it has ever been, in particular since the end of the cold war. Politics, and what is seen, more than ever, as its 
ugly and developmentally disabled cousin, power, are today too tasteless to even mention; what is described as the international community instead considers that it acts solely on principle, as expressed through legitimate legal institutions. That politics indeed operate here, even if they are occasionally explicitly mentioned and lauded for the positive aims of, say, establishing definitive political accounts, ${ }^{603}$ putting an end to impunity, or effecting political catharsis ${ }^{604}$ is in the current context unmentionable. This is legalism and a real legalism of ideology writ large: law in effect redeems then entirely obviates politics, as the idea that politics is a messy business remains unabated. Internationally, the idea of politics as reflecting a form of popular sovereignty, or a liberal view of democracy, cannot, despite great efforts genuinely yet hold. Not all states share these commitments, but all seek-or at least wish to be seen as seeking-resolution of international, and in some instances arguably strictly national, when the nation is a foreign one, disputes and punishment of international crimes through nonpolitical means and specifically legal fora. Thus, international legalism relies on the idea that law, as a vehicle for international relations, is unimpeachable, as only it rises above politics and generates results that secure consensus. This is not the legalism of lawyers seeking to separate the legal order from the moral or the political, this is a political legalism that denies its political provenance and objectives, in the interests of credibility and international support. International legalism demonstrates the current fear of international politics, and the current

\footnotetext{
603 Jenia Iontcheva Turner, "Defense Perspectives on Law and Politics in International Criminal Trials," 48 (3) Virginia Journal of International Law, 529-594 604 Michael Scharf, "Making a Spectacle of Himself: Milosevic Wants a Stage, Not the Right to Provide His Own Defense” Washington Post August 29th, 2004, p. B2.
} 
distaste for bargaining, debate and disagreement. Not much has changed, in that respect-though arguably the situation has deteriorated-since Shklar observed that same attitude towards political arrangements in international relations after the Second World War. ${ }^{605}$

Lawyers working before international law-like bodies are enlisted with tremendous ease in the pursuit of today's international legalism. As the deterrent effect of Socrates' trial and execution calmed the ardors of political theorists ever since, so, too, have the outraged reactions to political defenses, in particular that of Slobodan Milosevic, ${ }^{606}$ incited lawyers to stick very closely to their strictly legalist training. And if self-policing did not suffice, the ICTY's Directive on the Assignment of Counsel only deems lawyers eligible to act as defense counsel if they have not engaged in conduct, professionally or "otherwise" that is "likely to diminish public confidence in the International Tribunal (...) or otherwise bring the International Tribunal into disrepute."607 Lawyers at the ICTR have been sanctioned for complaining that the body was a political court, and that is precisely what it means to "diminish public confidence in a tribunal," or to bring it "into disrepute." This does not prevent tribunal employees or diplomatic representatives of all stripes from making political statements about the

605 Legalism, 133. See the contemporaneous review of Legalism making a similar observation: H. A. Bedau, "Review," The Philosophical Review, 76, (1( (Jan., 1967), 129-130, 129.

${ }^{606}$ Michael P. Scharf, "ICTY Appeals Chamber Decision on Slobodan Milosevic's Right to SelfRepresentation", American Society of International Law, Insight, November 2004, http://www.asil.org/insights/2004/11/insight041111.html; Ana Uzelac, "Milosevic Judges Face New Challenge", Institute for War and Peace Reporting, TU No 380, 05-Nov-04, on the web at: <http://www.iwpr.net/index.pl?archive/tri/tri_380_1_eng.txt >. For more on this question, see, Tiphaine Dickson and Aleksandar Jokic, "Hear no Evil, See no Evil, Speak no Evil: the Ugly Milosevic Case,"

${ }_{607}$ Directive on the Assignment of Defense Counsel, Directive 1/94, Article 14, (A) vii. 
tribunals' successes: it only prohibits characterizing those statements, and that particular approach to law, as political.

Academic efforts have also been invested into demonstrating that defense lawyers do not view the ad hoc bodies as "political."608 Jenia Iontcheva Turner's empirical study of international criminal defense lawyers' attitudes somewhat idiosyncratically construes Shklar's Legalism as defending the proposition that political trials establish definitive historical accounts of events (an idea that horrifies decent historians everywhere), ${ }^{609}$ and prevent revisionism, as well as the idea that due process would also prove too narrow in international criminal law. ${ }^{610}$ While each of these claims reveals a poor grasp of Shklar's global argument, the last is by far the worst offender, for nowhere does Shklar make such a claim: the narrowness she complains of in Turner's reference is explicitly conceptual and refers, in the context of the argument, to the manner in which legalism, as an ideology, is too inflexible to grasp its own creative potential. ${ }^{611}$ The problems for Shklar are not the constraints of fair procedures and individual culpability, as she was an ardent supporter of those very safeguards, but arise in the context of the legalists' self-serving belief that law's validity, and indeed superiority, is attributable to its hermetic separation from politics. ${ }^{612}$ How to express the irony of Turner's misapprehension in light of Gary Jonathan Bass's

608 Jenia Iontcheva Turner, "Defense Perspectives on Law and Politics in International Criminal Trials," 48 (3) Virginia Journal of International Law, 529-594, 534-535

609 See René Rémond, “L'histoire et la loi,” Études, June 2006. See too Carlo Ginzberg, Pierre Vidal-Nacquet et al in Libération 610 Turner, "Defense Perspectives on Law and Politics in International Criminal Trials," 535. ${ }^{611}$ Legalism, 112. 612 Ibid., 111. 
book, Stay the Hand of Vengeance, ${ }^{613}$ that develops a theory of due process liberalism on the polar opposite interpretation of Shklar's Legalism? However unconvincing Bass's treatment of liberal states' propensity to establish war crimes tribunals, how "faddish" 14 his attempt to loosely attach his argument to democratic peace theory, or how questionable it is to enlist Shklar, the notorious skeptic, in hegemonic-sounding claims of liberal virtue, at least to his credit, he does not portray Shklar as an opponent of due process.

The greater irony is perhaps that Turner's project ends up doing precisely what Shklar was deriding when she wrote about "legalism's traditional pieties," as the study reports that a robust majority of defense lawyers before both the ICTY and ICTR do not see the tribunals or their proceedings as political. The world can heave a sigh of relief; the emperor is fully clothed. It may not be clear to academic lawyers or to most political scientists deprived of the joys and pains of legal practice that it is fairly impossible for a defense lawyer actively involved in a criminal case (as those polled in Turner's study were)-much less when the accused is charged with offences as grave as genocide, crimes against humanity, and violations of the Geneva Conventions-not to convince herself that the evidence, her legal arguments, and the quality of her court performance (objections, cross-examinations, and the defense presented) does not have a decent chance of leading to an acquittal. No serious attorney presents a defense doomed to fail. More importantly, the idea that success can be secured, precisely

613 Gary Jonathan Bass, Stay the Hand of Vengeance: The Politics of War Crimes Tribunals, (Princeton: Princeton University Press, 2000).

614 Frédéric Mégret, “The Politics of International Criminal Justice” European Journal of International Law 13 (5) (2002): 1261-1284, 1270. 
because the procedure is legal, rather than political, is essential to a defense lawyer, and without it she should not, and generally cannot, participate as an advocate in a criminal trial. Thus Turner's results can hardly be deemed surprising or reassure anyone that if those hardest nuts to crack-the defense lawyers-believe the proceedings to be legal rather than political, then they must be exclusively legal. Attorneys in the midst of a high-pressure case are in general the least qualified to pronounce on the political nature of a court. Indeed, they have the most to gain from its strict adherence to the principles of legality. As Shklar wrote much later, adherents to legalism generally believe that with a normal system of law, injustices will be rare. ${ }^{615}$ Conversely, in order to believe that injustice will not be committed in a particular case, it is easy to convince oneself that in fact a normal system of justice is in place.

Legalism is a critique of a closed moral and professional system that in denying its political provenance and power, in particular when faced with genuinely political questions, offers nothing beyond its own internal norms of conduct. But it is also a potential creative force. Its iteration as a formalist defense of an accused is not inconsistent with Shklar's liberalism of fear, ${ }^{616}$ and argues in favor of those very fundamental safeguards, say an independent judiciary, without which no system of Rule of Law can be said to exist. 617

\footnotetext{
615 Judith N. Shklar, The Faces of Injustice (New Haven : Yale University Press, 1990), 17. ${ }^{616}$ Shklar, "The Liberalism of Fear," 18. 617 Judith Shklar, "Political Theory and the Rule of Law," in Judith N. Shklar, Political Thought and Political Thinkers, 25.
} 
Both kinds of legalism are ideological, in a very weak sense, simply referring, as Shklar intended, to political preferences. ${ }^{618}$ The first legalism denies that it prefers anything but the law, which is by definition sealed off from politics, and cannot ever therefore amount to a political preference. Any and all conflicts can be solved by recourse to the existing law, and adjudication provides clear, unambiguous, and legitimate answers to difficult problems. The second legalism, the potential creative force, illustrates itself not only, as argued here, in those quintessentially classical liberal defenses of individual freedom against the state or international criminal apparatus, but in the value of the trials themselves.

\section{Legalism and the Emergence of International Criminal Law}

It is by now well established that despite previous well-meaning attempts, international criminal trials tasked with the prosecution of individuals only emerged with the Nuremberg Tribunal following the Nazi defeat after the Second World War. ${ }^{619}$ Historical attempts to try Napoleon or Kaiser Wilhelm had failed, ${ }^{620}$ confronted by international law's most enduring (and possibly intractable) problem, that is its continued existence in a virtual state of nature, without a supervening authority capable of pronouncing judicially and enforcing

\footnotetext{
618 Shklar, Legalism, 4.

619 Jackson Nyamuya Maogoto, War Crimes and Realpolitik: International Justice from World War I to the 21st Century, (Boulder CO : Lynne Reinner Publishers, 2004), 77-100; Samantha Power, A Problem From Hell: America in an Age of Genocide, (New York : Basic Books, 2002), 49-50; Bass, Stay the Hand of Vengeance, 147-205; Stephanos Bibas and William Burke-White, “International Idealism Meets Domestic-Criminal-Procedure Realism,” 59 (4) Duke Law Journal, 2010, 637-704.

620 Bass, Stay the Hand of Vengeance , 37.
} 
its authority against individual states exercising sovereignty. ${ }^{621}$ Though this state of affairs did not genuinely change after the Second World War, and the formal arrangement of states remained one of anarchy, political will emerged strongly among the victorious Allied states to establish "law-like political institutions" 622 to prosecute the Nazi leadership (as well as the Japanese) for the waging of aggressive war and for a newly promulgated offense called "Crimes against Humanity." Shklar recognized-much to the dismay of those most committed to the legalist nature of the Nuremberg and Tokyo trials-that the policy to try individuals was not a purely legal endeavor, emerging fully-formed from nowhere: it was a result of politics, meant to promote decent political aims. Shklar's 1964 Legalism examines the unexplored tensions (and indeed the paradoxes and conflicts) that were apparent in these trials. Seen in a purely legalist light, they could be said to enjoy great international legitimacy, but that very same legalism paradoxically contributed to the erosion of the credibility of courts trying offenses that were not (at least technically) crimes at the time of their commission. And indeed, despite the establishment of the United Nations, not a single international criminal prosecution was carried out until after the cold war was over, with the establishment of the International Criminal Tribunal for the Former Yugoslavia in $1993 \cdot{ }^{623}$ Thus, it cannot be said that Nuremberg left a truly legalist legacy in its wake: the cold war, witness to many large-scale atrocities and undeniably prosecutable war crimes, appeared to promote the

\footnotetext{
${ }^{621}$ Immanuel Kant, Perpetual Peace, 1957, Liberal Arts Press, Lewis White Beck, ed., 103. 622 The expression is Shklar's: Legalism, 156.

623 Maogoto, War Crimes and Realpolitik, 237, Bass, Stay the Hand of Vengeance, 206-275.
} 
interests of the two superpowers more than it did the pursuit of an international criminal policy agenda. As Geoffrey Best put it, as late as in 1984, Nuremberg was "but a beacon behind us, growing ever fainter."624

This is not only because there was still no supranational authority that could compel states (but most crucially the U.S.A. and U.S.S.R.) to submit to a judicial authority, but on broader philosophical grounds. Shklar contended that Nuremberg should be seen as the political conclusion of a kind of politics (Nazism and fascism) and of a kind of war (World War II). Viewed in that light, Nuremberg could never stand as a precedent (legal or otherwise) but as a sui generis resolution of an ideological war of elimination-on both sides-which demanded the corresponding elimination, albeit by legal, or at least legalistic means, of its defeated leadership. ${ }^{625}$ The trial was thus a political act, "a powerful inspiration to the legalistic ethos," ${ }^{26}$ as opposed to a truly legal endeavor that could be referred to as having somehow modified the substance and much less the nature of international law. The value of Nuremberg was not, argues Shklar, that it recognized the legal force of the Hague Conventions or anything else; it was that Nazi political behavior-and specifically what it consisted of-as well as the fact that the allies, however disproportionate were the military means they employed, say in the fire-bombing of Dresden, were not comparable to the atrocities committed by the Nazis. These actions could thus be the object of international political pedagogy, rather than constituting any kind of legal

\footnotetext{
624 Geoffrey Best, Nuremberg and After: The Continuing History of War Crimes and Crimes Against Humanity (London : Southgate, 1984), 26.

625 Shklar, Legalism, 163.

626 Ibid., 170.
} 
precedent. Furthermore, despite the important symbolic contribution of Nuremberg to the collective conscience, its sister tribunal, Tokyo, did not benefit from such symbolic clarity. One need simply write the name of the German city that housed the International Military Trial to evoke the triumph of Westernstyle law over vengeance, then barbarity and indeed evil. In Tokyo, the political lessons made out with such eloquence against the Nazi leadership hardly could have convinced the Japanese. They did not even persuade all the judges, and the dissent of Indian judge Radhabinod Pal in particular illustrates how different Tokyo was. ${ }^{627}$ First, the "clean hands" of the Allies were much less apparent than in Nuremberg. As Bruno Simma noted: "Auschwitz was singularly German, and none of the offences committed by the Japanese political and military leaders came even close." ${ }^{28}$ Judge Pal was revolted that the Americans would try Japan for war crimes and crimes against Humanity after Hiroshima and Nagasaki: and indeed, such outrageous hypocrisy ${ }^{629}$ not only distinguished the lesson of Nuremberg from Tokyo's "political catastrophe," but it served to diminish the legal credibility of both bodies, when taken together. Second, argues Shklar, but far less compellingly, Japan lacked the culture of legalism ${ }^{630}$ that was a feature of German institutions-and, one might add, fairly evident in German intellectual production from Immanuel Kant to Hans Kelsen, and Max Weber in between-

\footnotetext{
627 Kirsten Sellars, “Imperfect Justice at Nuremberg and Tokyo," EJIL (2010), Vol. 21 No. 4, 1085-1102, 1094.

628 Bruno Simma, "The Impact of Nuremberg and Tokyo: Attempts at a Comparison", in A. Nisuke (ed.) Japan and International Law: Past, Present and Future (The Hague : Kluwer Law, 1999), 83.

${ }^{629}$ Shklar, Legalism, 1964, 161; R. B. Pal, Dissenting Judgment. International Tribunal for the Far East (Calcutta: Sanyal, 1953), 620-621. ${ }^{630}$ Legalism, 179-180.
} 
and which Nuremberg reignited. ${ }^{631}$ Furthermore, Joseph Keenan's insistence on arguing on the basis of just war theory, and his claim that it, as well as the natural law he deemed appropriate to frame as the basis of the prosecution, were universal as they flowed from Judeo-Christian civilization, were ultimately an embarrassment, the polar opposite of Nuremberg's much vaunted legacy. The lack of legitimacy of at least one of the two institutions diminished chances of compliance following the end of the post-war proceedings.

Shklar's approach answers Richard Falk's query as to "why sovereign states should have been ever willing to validate such a subversive idea as that of international criminal accountability of leaders for war crimes." This validation, pursued Falk, only made sense "if the imposition of accountability is understood to be a particularly advantageous response to a given geopolitical challenge whose wider implications can be avoided." ${ }_{32}$ And for America, the wider implications continue to be avoided, indeed.

Legalism was meant as a conceptual device serving precisely to illustrate the necessity of political will in the emergence of international criminal law. With the establishment of two ad hoc institutions trying individuals by the United Nations Security Council, as well as the nascent International Criminal Court (of which the U.S. is not a member state, and whose jurisdiction it continues to oppose, on the exceptionalist basis that the United States, does not commit

\footnotetext{
${ }^{631}$ Ibid., 168.

${ }_{632}$ Richard Falk, “Telford Taylor and the Legacy of Nuremberg”, 37 Colum J Transnat'l L (1999) 693, 710)
} 
aggression), ${ }^{633}$ legalism continues to provide a challenge both to the view that legal bodies can (or should) solve everything internationally, and that it could be politically decent not to try.

Legalism, International Politics, and the Politics of Memory

It is possible to doubt the transformative effects of international norms. Particularly in international politics, when legalism clashes with the demands of politics, prudence may guide national leaders toward the latter. As Stephen Krastner has observed, in an international environment in which "there are many demands, multiple norms, power asymmetries, and no authoritative decisionmaking structures," states are socialized to international norms imperfectly. ${ }^{634}$

Besides the variance in state norms, and the absence of authoritative decision-making structures, there is the more important fact of the absence of international enforcement power; this, argues Eric Posner, makes international law “unavoidably weak.”635 Posner considers international law not as what Shklar would characterize as something that is "there," but rather as a collective action problem, to be conceived of and grasped with the tools of rational choice theory. Posner's “legalism," like that of many contemporary thinkers, suffers from

\footnotetext{
633 Barack Obama, National Security Strategy, 2010; Harold Koh, "U.S. Engagement With The International Criminal Court and The Outcome Of The Recently Concluded Review Conference," US Department of State, Special Briefing, June 15 $5^{\text {th }}$ 2010, http://www.state.gov/s/wci/us_releases/remarks/143178.htm.

634 Stephen Krasner, Sovereignty: Organized Hypocrisy, (Princeton: Princeton University Press, 1999), 9.

635 Eric Posner, The Perils of Global Legalism, (Chicago: University of Chicago Press, 2009), xiv; 31-32.
} 
serving merely as a straw man-or at best an extra-in support of what is the author's actual theory. Posner's association of rational choice theory to a classical realist framework to analyze international law is not without a great deal of appeal. State interests and the (still) anarchical distribution of power internationally constitute a lucid, and therefore helpful way of looking at international law. However, what is missing in Posner's otherwise excellent critique is perhaps the nuance in thinking, that continuum developed by Shklar between the legal and the political extremes, incorporating morality, and the understanding that-as legal theorists like Martti Koskenniemi have done-the new "ethical turn" in international legalism, that recourse to morality (or rather moralization) at the expense of law, best exemplified by the self-consciously “illegal but legitimate" NATO bombing of Serbia in 1999, while presenting an alternative to formalized legalism, may serve hegemonic politics, and is profoundly conservative in nature. In turn, the obsession to formalize political problems (what I have called "international legalism"), while, as writes Koskenniemi, "understandable in historical perspective, enlists political energies to support causes dictated by the hegemonic powers and is unresponsive to the violence and injustice that sustain the global everyday." ${ }_{36} 6$

Another way to examine the post cold war international landscape would be to analyze degrees of legalism, while attempting to respect democratic (political) choices made by different societies along a continuum ranging from international regimes demanding formal accountability and retribution, to 
collective political responsibility and reconciliation. ${ }^{637}$ The realization of social peace in post-conflict states is often owed to the decision to defer immediate justice to political negotiations. ${ }^{638}$ Moreover, the deterrent effect of justice can be significantly limited when a society is trapped in a perverse-equilibrium-a situation in which individuals are unwilling to stop abusive practices unless everyone credibly commits to ending them. ${ }^{639}$ Overcoming these challenges often requires providing amnesties, and bargaining with key leaders of the previous regime who otherwise may be inclined to derail the process of post-conflict institution building. The South African Truth and Reconciliation Commission, and the amnesties granted by Spain in order to confront its fascist past-of interest in light of Spain's attempts to prosecute Augusto Pinochet despite newly democratic Chile's political decision to grant him immunity as a senator ${ }^{640}-$ constitute recent examples of non-legalistic approaches to addressing problems of political transition.

It is precisely in cases of political transition-known somewhat hopefully as “democratic transitions"-that Shklar's arguments in Legalism have been deployed the most disconcertingly. Mark Osiel, for instance, argues that an expansion of Shklar's work demands a defense of the liberal show trial,

\footnotetext{
${ }^{637}$ Paul W. Kahn, “American Hegemony And International Law: Speaking Law To Power: Popular Sovereignty, Human Rights, And The New International Order," 1 (1) Chicago Journal of International Law, 2000, 1,5 . ${ }^{6} 38$ Jack Snyder and Leslie Vinjamuri, “ Trials and Errors : Principle and Pragmatism in Strategies of International Justice," International Security 28 (3) (2003) 18-20, 13. Snyder and Vinjamuri $(2003,13)$ ${ }^{639}$ Suzanne Katzenstein and Jack Snyder, "The Expediency of Angels," The National Interest, March 2009, 59, 63. ${ }^{640}$ Kenneth A. Rodman, (2006) "Compromising Justice: Why the Bush Administration and the NGOs Are Both Wrong about the ICC," Ethics \& International Affairs 20 (1), 25, 42-43.
} 
"monumental spectacles," he writes, with no apparent sign of irony; "yarns," "narratives," and "stories" that would require prosecutors to familiarize themselves with the local conventions of narrative genres ${ }^{641}$ (it is assumed, apparently, that prosecutors will be English-language readers of Osiel's work sent to far-away locales where the indigenous storytelling will be unfamiliar to them). Osiel means this for the sake of establishing-or rekindling-liberalism's great virtues in societies recovering from what he calls "administrative massacres," and discouraging the vices that that threaten liberalism most of all. The worst of these vices, Osiel offers, is cruelty, curiously failing to acknowledge Shklar, whose best known work, Ordinary Vices, loosely inspired by Montaigne's Essays, is precisely devoted to an erudite examination of vices in liberal societies, and concludes that cruelty is the one that liberalism must foremost eschew to preserve its nature. ${ }^{642}$ But Osiel seeks something else entirely. In contrast to the kind of tolerance that Shklar defended throughout her career, Osiel seeks a wholesale modification of collective memory in communities affected by massacres, and argues that this be done-in the pursuit of liberal virtues-through the use of gripping narratives and "vivid yarns," spun not around campfires, but in courtrooms, in real criminal cases where individuals' freedom-Osiel seems to momentarily forget just how crucial this is to liberalism-is a stake. Acknowledging-as surely he must-that some lawyers might cringe (the term seems weak) at the idea, Osiel nonetheless offers that interesting narratives, despite the risk, by promoting appeal to the

${ }^{641}$ Mark J. Osiel, "In Defense of Liberal Show Trials-Nuremberg and Beyond," in Perspectives on the Nuremberg Trial, Guénaël Mettraux, ed. (Oxford: Oxford University Press, 2008), 704, 704709.

642 Judith Shklar, Ordinary Vices, (Cambridge, MA: Harvard University Press, 1984). 
sentiments of the general public, that they could compromise the historical record, are useful in creating the decent politics of the sort Shklar thought justified at Nuremberg. Osiel's goal is pedagogical, but one is hard-pressed to find a compelling reason why schools could not teach these heroic stories to inculcate the virtues of liberalism and the condemnation of its vices, rather than instrumentalizing courts and judicial procedures, and thus perverting those very liberal values in so doing. What is liberalism if it requires state-sponsored history to create a consensus of sentiment? Something surely much unlike liberalism, indeed. In Osiel's liberalism of consensus, history fares not much better. $\mathrm{He}$ defends his use of socially salubrious court-made myths on the basis that the legal system is accustomed tolerating competing narratives. He concludes that "courts may legitimately tailor the stories they tell in order to persuade skeptical publics of the merits of liberal morality. But they may not exclude incompatible stories from public hearing." 643 Osiel's idea is that historians can eventuallybecause in a liberal society they are entitled to differ-offer narratives that diverge from the official legal version of history. One is challenged whether to be first struck by his grandiose naiveté or by the Orwellian flavor of this social proposal.

Legalism, when cast as a potentially creative force promoting decent politics can acknowledge that some politics inevitably promote specific interests, and in many cases, those are the interests of the powerful to the detriment of the weak. Moral arguments are only as solid as the facts that support them, and

643 Mark J. Osiel, Mass Atrocity, Collective Memory, and the Law (New Brunswick/London: Transaction Publishers, 1997), 141. 
where legality - if not legalism - provide protection against idiosyncratic actions of a potentially unjust and politically tragic nature, committed often by the most powerful, is in evaluating evidence, in what legalists of the organic type hope at least will be a dispassionate manner. As Koskennemi puts it, "against the particularity of the ethical decision, formalism constitutes a horizon of universality, embedded in a culture of restraint, a commitment to listening to others' claims and seeking to take them into account." ${ }^{44}$ Saying it does not make it so, and for all the weaknesses of legalism, at least it cherishes the idea of considering all sides of an argument, as stated in the legal maxim audi alteram partem. Legalism's formality may be impossible to effect as a result of the nature of international relations, ${ }^{645}$ or its time may simply be past; 646 if this is true it ought not, however, discourage the self-reflexivity required of all those who deploy their efforts in the trenches or on the margins of international law, in particular those involved in international criminal trials. The all-or-nothing thinking, may, as Shklar argued, be characteristic of lawyers, but it presents itself nonetheless, in matters of such gravity, as a prudent alternative to not thinking at all.

\footnotetext{
644 Koskenniemi, id., 174. 645 Hans Morgenthau, Politics Among Nations: The Struggle for Power and Peace, $6^{\text {th }}$ ed. (New York: Knopf) 327.

646 Koskenniemi, 174.
} 


\section{Epilogue: A Salutary Demise}

"We must never forget that the record on which we judge these defendants is the record on which history will judge us tomorrow. To pass these defendants a poisoned chalice is to put it to our own lips as well."

Justice Robert Jackson, Opening Address to the International Military Trial, November 10th, 1945

The varied enthusiasms in favor of the establishment of international criminal "lawlike"647 bodies that characterized 1990s scholarship and activismrekindling the legacy of Nuremberg, exporting Western legalism and human rights to the needy, writing history and effecting reconciliation- stand in stark contrast to what I have found to exist and motivate actual international criminal law. At the outset, I made clear that this work reflected the disposition of a skeptic. This epilogue is meant to test the limits of that skepticism.

The question can be posed quite clearly: can the enterprise of international criminal law, once its myriad shortcomings and perversions identified and analyzed, be reformed and thus retain its promise to create an international regime of norms reflecting the rule of law to be applied equally to all?

Those who would champion the cause of reform look forgivingly at international criminal law's shortcomings; instead they choose to see "a fledgling cause that needs to be sheltered from the ordinary conditions of inquiry," 648 and crucially, a cause that deserves time to self-correct whatever lacunae might blemish the great cause of ending impunity. In the meantime, individuals are

647 Judith Shklar, Legalism: Law, Morals, and Political Trials (Harvard University Press, 1964), 156.

648 As described by Samuel Moyn, "Towards Instrumentalism at the ICC," 39 The Yale Journal of International Law Online, (2014), 62 
prosecuted, and in some cases, the decisions of sovereign states' highest courts are blithely disregarded, while the conspicuous and unavoidable reality of power in international relations works to create a de facto situation where the three most powerful states in the world-and permanent members of the United Nations Security Council: The United States, China, and the Russian Federation-are not, and show no signs of wanting to become members of the International Criminal Court. Many states in the African continent have expressed their dissatisfaction with the court's sole prosecution of Africans, and the African Union has voted in favor of-but has yet to ratify-the establishment of a regional body with jurisdiction over the main international criminal offenses, as well as other proposed crimes, arguably more suited to specific legal preoccupations of the continent. ${ }^{649}$ Of special note are environmental offenses, trafficking offenses, as well as the ability to prosecute corporations. Contrary to the ICC, the African Court of Justice and Human and Peoples Rights does not contain an opt out clause for the crime of aggression, held by the Nuremburg tribunal to be the "supreme international crime." The offenses envisaged in the African Union body are the following:

- genocide;

- crimes against humanity;

- war crimes;

- the crime of unconstitutional change of government;

- piracy;

\footnotetext{
649 Beth Van Schaak, "Immunity Before the African Court of Justice \& Human \& Peoples Rightsthe Potential Outlier," Just Security, https://www.justsecurity.org/12732/immunity-africancourt-justice-human-peoples-rights-the-potential-outlier/
} 
- terrorism;

- mercenarism;

- corruption;

- money laundering;

- trafficking in persons;

- trafficking in drugs;

- trafficking in hazardous wastes;

- illicit exploitation of natural resources; and

- the crime of aggression.

As the original two ad hoc tribunals created by the UN Security Council in the 1990 come to a close, the question of the preservation of international criminal law depends largely on the legitimacy to be afforded to the ICC, and at present, that is challenged both by non-participation by powerful states, as well as by the African Union's bold legal rejoinder. Even once reservedly supportive veteran Western observers of the court have come to critique its "prudent cowardice, that looks only at the crimes of failed, routed peoples, and forgets those of nations that impose their domination." ${ }^{60}$

If the ICC could realistically be reformed, it would be possible to conceive of something like a checklist of deficiencies in order to then go about applying appropriate corrective measures. It might cease disregarding decisions of domestic supreme courts; it might refuse to follow Security Council referrals as in the catastrophic case of Libya-but no, it actually could not. And it seems fairly clear that there will not be Russian and Chinese participation in such initiatives pénale internationale, (Paris : Editions Don Quichotte, 2016). 
for at least the next two decades. There stops the checklist. It could not in any likelihood, as Palestine so ardently wishes, investigate Israelis; it will not prosecute American actions in Afghanistan (as some legalistically dream), and after all, as the late British Foreign Secretary Robin Cook put it, the ICC "was not set up to bring to book Prime Ministers of the United Kingdom or Presidents of the United States.”651

Inequality before international criminal courts, and within the powerful states that promote the soon to be bankrupt project demands a return to AnneMarie Slaughter's caution about international normative institutions: the time is ripe to assert that indeed they have evolved in manner disconcertingly reminiscent of $19^{\text {th }}$ century distinctions between civilized and uncivilized. Even Radhabinod Pal's seething dissent in the Tokyo trials seems appropriate in examining the ICC today, ${ }^{652}$ and though it cannot be said that contemporary international relations reflects the kind of colonialism-though it may well constitute another653 - against which he justifiably railed, it is nonetheless apparent that the ICC can do nothing to afflict the comfortable, and has done far too little to comfort the afflicted.

Against the idealism of the proponents of the international criminal justice project is raised a materialist diagnosis: the costs of the endeavor are simply too high, both at home and abroad. Another idealism is required: that which would

${ }^{651}$ Cited in Latha Varadarajan, "The Trials of Imperialism: Radhabinod Pal's Dissent at the Tokyo Tribunal," European Journal of International Relations, December 10, 2014, doi:10.1177/1354066114555775, 17.

652 Ibid.

653 Ibid. Varadarajan notes that the ICC has only prosecuted individuals from Africa. The continent's wealth in raw materials, overt foreign military operations there, and the ICC's prosecutorial strategy are not, she contends, "mere coincidence." 
shift the focus of rights and law discourse-and eventually practice-from a collective summum malum to a broader project of summum bonum. A genuine reclamation of American virtue surely requires attention to the shocking reality of income inequality, its impact on education, health, life expectancy, and indeed democracy, rather than a miserly focus on atrocities abroad, while US foreign policy itself has in too many ways failed to "stay the hand of vengeance."

Skepticism can easily be confused with pessimism, even cynicism, but it is truly pessimistic not to mourn the coming demise of a failed, costly and distracting project? History appears to be proving that the early optimism in the international criminal law project was at the very least misplaced. And as Isaac Deutscher put it, "Awareness of historical perspective seems to me to provide the best antidote to extravagant pessimism as well as extravagant optimism over the great problems of our time." 554

Seen this way, the emergence of post cold-war international criminal law looks less like Nuremberg, and much more like Tokyo: a tribunal the world would have been better off without. It is time to abandon international prosecutorial zeal and turn instead to "the great problems of our time" at home, without extravagance, but with clear-minded determination for the greater good.

654 Isaac Deutscher, Heretics and Renegades (London: Hamish Hamilton, 1955), p. 7. 


\section{Bibliography}

"A Return To Flint, Where The Mayor Has Declared A State Of Emergency." NPR.org. (2015). http://www.npr.org/2015/12/19/460414818/a-returnto-flint-where-the-mayor-has-declared-a-state-of-emergency.

Abbott, K. Robert Keohane, Andrew Moravscik A, et al., "The concept of legalization," International Organization 54 (3) (2000): 401-419.

Adler, Les, and Thomas Paterson. "Red Fascism: The Merger of Nazi Germany and Soviet Russia in the American Image of Totalitarianism, 1930s1950s," American Historical Review 74 (April 1970): 1046-1064.

"Al-Aulaqi v. Obama-Constitutional Challenge to Proposed Killing of U.S. Citizen." American Civil Liberties Union, October 19, 2011.

Al Bulushi, Samar and Adam Branch, "AFRICOM and the ICC: Enforcing International Justice in Africa?," Pambazuka, May 27, 2010.

American Servicemembers Protection Act of 2002, (P.L. 107-206, Title II).

American Society of International Law Independent Task Force, U.S. Policy Toward the International Criminal Court: Furthering Positive Engagement, (Washington DC: American Society of International Law, 2007).

Amnesty International, "International Criminal Tribunal for Rwanda: Trials and Tribulations", AI Index: IOR 40/03/97 (March 1997).

Amnesty International, "International Criminal Court: U.S. Efforts to Obtain Impunity for Genocide, Crimes Against Humanity and War Crimes," IOR 40/025/2002 (Sept. 2, 2002).

Amnesty International, Fair Trials Manual, at <http://www.amnesty.org/ailib/intcam/fairtrial/indxftm_b.htm\#14>.

Anderson, C. "The Political Economy of Charles E. Lindblom," The American Political Science Review, 72 (3) (1978): 1012-1016.

Anderson, Kenneth. "The Rise of International Criminal Law: Intended and Unintended Consequences," European Journal of International Law 20, no. 2 (April 1, 2009): 331-58.

Aristotle. Politics (Oxford: Oxford University Press, 1995).

Anghie, Antony. Imperialism, Sovereignty, and the Making of International Law. (Cambridge: Cambridge University Press, 2007). 
Arieff, Alexis Rhoda Margesson, Marjorie Ann Browne, and Matthew C. Weed, "International Criminal Court Cases in Africa: Status and Policy Issues," Congressional Research Service Report, July 2011.

Arthur, Paige. "How ‘Transitions' Reshaped Human Rights: A Conceptual History of Transitional Justice." Human Rights Quarterly 31 no. 2 (2009): 32167.

Aumann, Francis R. "Review," The Journal of Politics 27, no. 3 (1965): 703-705.

Badar, M.E. “Just Convict Everyone!"-Joint Perpetration: From Tadic to Stakic and Back Again," International Criminal Law Review 6 (2006): 293.

Bacevich, Andrew J. and Eliot. A. Cohen (eds.), War over Kosovo: Politics and Strategy in a Global Age (New York: Columbia University Press, 2001).

Bachrach, P., \& Baratz, M. S. “Two Faces of Power," The American Political Science Review, 56(4) (1962): 947-952.

Baker, James Addison. The Politics of Diplomacy: Revolution, War, and Peace, 1989-1992. New York: Putnam, 1995.

Bass, Gary J. “Victor's Justice, Selfish Justice,” Social Research 69 (4) (2002): 1035-1044.

Bass, Gary J. Freedom's Battles: The Origins of Humanitarian Intervention (New York: Knopf, 2008).

Bass, Gary Jonathan. Stay the Hand of Vengeance: The Politics of War Crimes Tribunals (Princeton, N.J.: Princeton University Press, 2000).

Bass, Gary Jonathan. "War Crimes Tribunals," in Kenneth Wittington, R. Daniel Keleman, and Gregory A. Caldeira, (eds.), The Oxford Handbook of Law and Politics, (Oxford: Oxford University Press, 2008).

Bass, Gary Jonathan. "Victor's Justice, Selfish Justice," Social Research 69 (4) (2002): 1035-1044.

Baumgartner, F. \& Leech, B. Basic Interests: The Importance of Groups in Politics and in Political Science. (Princeton, NJ: Princeton University Press, 1998).

Bartov, Omer. "Chambers of Horror: Holocaust Museums in Israel and the United States," Israel Studies 2, no. 2 (1997): 66-87.

Becker, Jo, and Scott Shane. "Secret 'Kill List' Tests Obama's Principles" The New York Times, May 29, 2012.

3, Rodney Hawkins CBS News September, 2012, and 2:39 Pm. "Biden: We Are Better Off, 'Bin Laden Is Dead and General Motors Is Alive." Accessed December 21, 
2015. http://www.cbsnews.com/news/biden-we-are-better-off-bin-ladenis-dead-and-general-motors-is-alive/.

"Abdullah Al-Senussi Execution: This Perversion of Justice Suits Western Security Services Just Fine | Voices | The Independent." Accessed December 12, 2015. http://www.independent.co.uk/voices/abdullah-al-senussi-execution-thisperversion-of-justice-suits-western-security-services-just-fine10433785.html.

"Al-Aulaqi v. Obama - Constitutional Challenge to Proposed Killing of U.S. Citizen." American Civil Liberties Union. Accessed December 6, 2015. https://www.aclu.org/cases/al-aulaqi-v-obama-constitutional-challengeproposed-killing-us-citizen.

Anderson, Kenneth. "The Rise of International Criminal Law: Intended and Unintended Consequences." European Journal of International Law 20, no. 2 (April 1, 2009): 331-58. doi:10.1093/ejil/chp030.

Anghie, Antony. Imperialism, Sovereignty, and the Making of International Law. Cambridge, UK; New York: Cambridge University Press, 2007.

Arthur, Paige. "How 'Transitions' Reshaped Human Rights: A Conceptual History of Transitional Justice." Human Rights Quarterly 31, no. 2 (2009): 321-67. doi:10.1353/hrq.0.0069.

Baker, James Addison. The Politics of Diplomacy: Revolution, War, and Peace, 19891992. New York: Putnam, 1995.

Bartov, Omer. "Chambers of Horror: Holocaust Museums in Israel and the United States." Israel Studies 2, no. 2 (1997): 66-87.

Bass, Gary Jonathan. Stay the Hand of Vengeance: The Politics of War Crimes Tribunals. Princeton, N.J.: Princeton University Press, 2000.

Becker, Jo, and Scott Shane. "Secret 'Kill List' Tests Obama's Principles." The New York Times, May 29, 2012.

http://www.nytimes.com/2012/05/29/world/obamas-leadership-in-waron-al-qaeda.html.

Beneyto, José María, and David Kennedy. New Approaches to International Law: The European and the American Experiences. Springer, 2013.

Bloch, Marc. The Historian's Craft. Manchester University Press, 1992.

Considered, All Things. "A Return To Flint, Where The Mayor Has Declared A State Of Emergency." NPR.org. Accessed December 20, 2015. http://www.npr.org/2015/12/19/460414818/a-return-to-flint-where-themayor-has-declared-a-state-of-emergency. 
Crownshaw, Richard, and Jane Kilby. The Future of Memory. New York: Berghahn Books, 2010.

Czarnetzky, John M., and Ronald J. Rychlak. "Empire of Law: Legalism and the International Criminal Court, An." Notre Dame Law Review 79 (2004 2003): 55.

Davies, Nicolas J. S. Blood on Our Hands: The American Invasion and Destruction of Iraq. Nimble Books LLC, 2010.

Dezalay, Yves, and Mikael Rask Madsen. "The Force of Law and Lawyers: Pierre Bourdieu and the Reflexive Sociology of Law." Annual Review of Law and Social Science 8, no. 1 (2012): 433-52. doi:10.1146/annurev-lawsocsci102811-173817.

Drezner, Daniel W. "Ideas, Bureaucratic Politics, and the Crafting of Foreign Policy." American Journal of Political Science 44, no. 4 (October 2000): 733. doi:10.2307/2669278.

Galbraith, John Kenneth. The Affluent Society. Houghton Mifflin Harcourt, 1998.

"Get the Data: Drone Wars Archives." The Bureau of Investigative Journalism. Accessed December 6, 2015. https://www.thebureauinvestigates.com/category/projects/drones/dronesgraphs/.

Gilman, Nils. "The Twin Insurgency." Features. Accessed August 12, 2014. http://www.the-american-interest.com/articles/2014/06/15/the-twininsurgency/.

Hazan, Pierre, and James Thomas Snyder. Justice in a Time of War: The True Story Behind the International Criminal Tribunal for the Former Yugoslavia. Translated by James Thomas Snyder. Texas A\&M University Press, 2004.

Hilberg, Raul. Perpetrators, Victims, Bystanders: The Jewish Catastrophe, 1933-1945. HarperCollins, 1992.

- - - The Destruction of the European Jews, 3 Volume Set. 3rd ed. Yale University Press, 2003.

- - - The Politics of Memory: The Journey of a Holocaust Historian. Ivan R. Dee, 2002.

"How Team Obama Justifies the Killing of a 16-Year-Old American - The Atlantic." Accessed December 6, 2015. http://www.theatlantic.com/politics/archive/2012/10/how-team-obamajustifies-the-killing-of-a-16-year-old-american/264028/. 
"Human Rights and the Age of Inequality | openDemocracy." Accessed December 10, 2015. https://www.opendemocracy.net/openglobalrights/samuelmoyn/human-rights-and-age-of-inequality.

Huntington, Samuel P. The Third Wave: Democratization in the Late 20th Century. Norman: University of Oklahoma Press, 1993.

International Human Rights Lexicon. 1 edition. Oxford University Press, 2005.

International Military Tribunal. Trial of the major war criminals before the International Military Tribunal, Nuremberg, 14 November 1945-1 October 1946. Nuremberg, Germany: [s.n.], 1947.

Johnstone, Diana. Fools' Crusade: Yugoslavia, NATO, and Western Delusions. New York: Monthly Review Press, 2002.

Jokic, Aleksandar. “Genocidalism.” The Journal of Ethics 8 (2004): 251-97.

Kahn, Paul. "From Nuremberg to the Hague: The United States Position in Nicaragua v. United States and the Development of International Law." Faculty Scholarship Series, January 1, 1987. http://digitalcommons.law.yale.edu/fss_papers/339.

- - - "From Nuremberg to the Hague: The United States Position in Nicaragua v. United States and the Development of International Law." Faculty Scholarship Series, January 1, 1987. http://digitalcommons.law.yale.edu/fss_papers/339.

- _- "Speaking Law to Power: Popular Sovereignty, Human Rights, and the New International Order." Faculty Scholarship Series, January 1, 2000. http://digitalcommons.law.yale.edu/fss_papers/329.

Kahn, Paul W. "Imagining Warfare." European Journal of International Law 24, no. 1 (February 1, 2013): 199-226. doi:10.1093/ejil/chs086.

Kahn, P. W. "Imagining Warfare." European Journal of International Law 24, no. 1 (April 7, 2013): 199-226. doi:10.1093/ejil/chs086.

Kant, Immanuel. Kant: Political Writings. Edited by H. S. Reiss. Translated by H. B. Nisbet. 2nd ed. Cambridge University Press, 1991.

Kertesz, Imre, and John MacKay. "Who Owns Auschwitz?" The Yale Journal of Criticism 14, no. 1 (2001): 267-72. doi:10.1353/yale.2001.0010.

"Killer Drones: How America Goes to War in Secret by Michael Hastings | Politics News | Rolling Stone." Rollingstone.com. Accessed June 26, 2013. http://www.rollingstone.com/politics/news/the-rise-of-the-killer-droneshow-america-goes-to-war-in-secret-20120416. 
Koskenniemi, Martti. The Gentle Civilizer of Nations: The Rise and Fall of International Law 1870-1960. Cambridge University Press, 2004.

Maier, Charles S. "A Surfeit of Memory? Reflections on History, Melancholy and Denial." History and Memory 5, no. 2 (October 1, 1993): 136-52.

Maogoto, Jackson Nyamuya. War Crimes and Realpolitik. Lynne Rienner Publishers, Incorporated, 2004.

Mazower, Mark. Governing the World: The History of an Idea. Penguin Press HC, The, 2012.

McBride, Joseph. Steven Spielberg: A Biography (Third Edition). Faber \& Faber, 2012.

McDougall, Carrie. The Crime of Aggression Under the Rome Statute of the International Criminal Court. Cambridge University Press, 2013.

Mégret, Frédéric. "The Politics of International Criminal Justice." European Journal of International Law 13, no. 5 (2002): 1261-84.

Meister, Robert. After Evil: A Politics of Human Rights. New York: Columbia University Press, 2012.

Mettraux, Guénaël. Perspectives on the Nuremberg Trial. Oxford; New York: Oxford University Press, 2008.

Molloy, Antonia. "Saif Al-Islam Gaddafi, Son of Libya's Former Dictator, to Go on Trial for War Crimes." The Independent. Accessed September 19, 2014. http://www.independent.co.uk/news/world/middle-east/saif-alislamgaddafi-son-of-libyas-former-dictator-to-go-on-trial-for-war-crimes9257593.html.

"More Predator Drone Debate, in the Wall Street Journal, and What the Obama Administration Should Do as a Public Legal Position - The Volokh Conspiracy." Accessed December 6, 2015. http://volokh.com/2010/01/09/more-predator-drone-debate-in-the-wallstreet-journal-and-what-the-obama-administration-should-do-as-a-publiclegal-position/.

Morgenthau, Hans Joachim. Scientific Man vs. Power Politics. University of Chicago Press, 1967.

Morgenthau, Hans Joachim, and Kenneth W. Thompson. Politics among Nations: The Struggle for Power and Peace. Knopf, 1985.

Moyn, Samuel. "A Powerless Companion: Human Rights in the Age of Neoliberalism." Law and Contemporary Problems, 2014. General OneFile.

- - - Human Rights and the Uses of History. Verso, 2014. 
- - - "Substance, Scale, and Salience: The Recent Historiography of Human Rights." Annual Review of Law and Social Science 8, no. 1 (December 2012): 123-40. doi:10.1146/annurev-lawsocsci-102811-173847.

-_- The Last Utopia: Human Rights in History. Reprint. Belknap Press, 2012.

Murphy, Sean D. United States Practice in International Law: 1999-2001. Cambridge University Press, 2002.

"Naomi Klein Smackdown Roundup." The Economist. Accessed December 14, 2015. http://www.economist.com/blogs/freeexchange/2007/10/naomi_klein_sm ackdown_roundup.

Neier, Aryeh. Taking Liberties: Four Decades In The Struggle For Rights. PublicAffairs, 2005.

Newton, Michael A. Enemy of the State: The Trial and Execution of Saddam Hussein. First Edition edition. New York: St. Martin's Press, 2008.

Novick, Peter. The Holocaust in American Life. Boston: Houghton Mifflin, 2000.

"Obama's Speech on Drone Policy." The New York Times, May 23, 2013, sec. U.S. / Politics. http://www.nytimes.com/2013/05/24/us/politics/transcript-ofobamas-speech-on-drone-policy.html.

opinion, What in the world? Pieces of global. "Study: US Is an Oligarchy, Not a Democracy." BBC News. Accessed February 14, 2016. http://www.bbc.com/news/blogs-echochambers-27074746.

Peck, James. Ideal Illusions: How the U.S. Government Co-Opted Human Rights. New York: Metropolitan Books, 2010.

Piketty, Thomas. Capital in the Twenty-First Century. First Edition edition. Cambridge Massachusetts: Belknap Press, 2014.

Posner, Eric A. The Perils of Global Legalism. Chicago: University of Chicago Press, 2009. http://public.eblib.com/EBLPublic/PublicView.do?ptiID=471901.

Power, Samantha. A Problem from Hell: America and the Age of Genocide. Basic Books, 2002.

"Profile: Abdullah Al-Senussi." BBC News. Accessed December 12, 2015. http://www.bbc.com/news/world-middle-east-17414121.

Rakoff, Jed S. "The Financial Crisis: Why Have No High-Level Executives Been Prosecuted?" The New York Review of Books, January 9, 2014. http://www.nybooks.com/articles/archives/2014/jan/09/financial-crisiswhy-no-executive-prosecutions/. 
"Realities Behind Prosecuting Big Banks." DealBook. Accessed September 10, 2014. http://dealbook.nytimes.com/2013/03/11/big-banks-go-wrong-but-pay-alittle-price/.

"Reclaiming American Virtue - Barbara J. Keys | Harvard University Press." Accessed August 11, 2014. http://www.hup.harvard.edu/catalog.php?isbn=9780674724853.

"Relative of Americans Killed by Drone Strikes: No Justice in U.S. Courts." American Civil Liberties Union. Accessed December 6, 2015. https://www.aclu.org/blog/relative-americans-killed-drone-strikes-nojustice-us-courts.

Rosenfeld, Alvin H. The End of the Holocaust. First Edition edition. Bloomington: Indiana University Press, 2011.

_-_. The End of the Holocaust. Indiana University Press, 2011.

Scharf, Michael P. Balkan Justice: The Story behind the First International War Crimes Trial since Nuremberg. Durham, N.C.: Carolina Academic Press, 1997.

Scheuerman, William E. "Realism and the Left: The Case of Hans J. Morgenthau." Review of International Studies 34, no. 01 (2008): 29-51. doi:10.1017/S0260210508007894.

Seidman, Naomi. "Elie Wiesel and the Scandal of Jewish Rage." Jewish Social Studies 3, no. 1 (1996): 1-19.

Semple, Kirk. "Saddam Hussein Is Sentenced to Death." The New York Times, November 5, 2006, sec. International / Middle East. http://www.nytimes.com/2006/11/05/world/middleeast/05cndsaddam.html.

Shane, Scott. "The Lessons of Anwar Al-Awlaki." The New York Times, August 27, 2015. http://www.nytimes.com/2015/08/30/magazine/the-lessons-ofanwar-al-awlaki.html.

Shklar, Judith. Legalism: Law, Morals, and Political Trials. Harvard University Press, 1964.

Shklar, Judith N. A Life of Learning. American Council of Learned Societies, 1989. http://www.acls.org/uploadedFiles/Publications/OP/Haskins/1989_Judith NShklar.pdf.

_-_. Ordinary Vices. Belknap Press of Harvard University Press, 1985.

Silet, Charles L. P. The Films of Steven Spielberg: Critical Essays. Scarecrow Press, 2002. 
Slaughter, Anne-Marie. "International Law in a World of Liberal States." European Journal of International Law 6, no. 1 (January 1, 1995): 503-38. doi:10.1093/ejil/6.1.503.

Snyder, Jack L., and Leslie Vinjamuri. "Trials and Errors: Principle and Pragmatism in Strategies of International Justice." International Security 28, no. 3 (n.d.): $5-44$.

Stone, Dan. The Holocaust and Historical Methodology. Oxford: Berghahn Books, 2012.

“The Anwar Al-Awlaki File." Accessed December 6, 2015. http://nsarchive.gwu.edu/NSAEBB/NSAEBB529-Anwar-al-Awlaki-File/.

“The Demise of International Criminal Law." Accessed July 29, 2014. http://www.humanityjournal.net/blog/the-demise-of-internationalcriminal-law/.

"U.S. Airstrike That Killed American Teen in Yemen Raises Legal, Ethical Questions The Washington Post." Accessed December 6, 2015. https://www.washingtonpost.com/world/national-security/us-airstrikethat-killed-american-teen-in-yemen-raises-legal-ethicalquestions/2011/10/20/gIQAdvUY7L_story.html.

Varela, Justo Corti, John Haskell, José María Beneyto, and David Kennedy. New Approaches to International Law: The European and the American Experiences. 1st ed. Dordrecht: Springer, 2012.

Vucinich, Wayne S., Jozo Tomasevich, and Stanford University. Contemporary Yugoslavia: Twenty Years of Socialist Experiment. University of California Press, 1969.

Williams, Michael C. "Why Ideas Matter in International Relations: Hans Morgenthau, Classical Realism, and the Moral Construction of Power Politics." International Organization 58, no. 4 (October 1, 2004): 633-65. doi:10.2307/3877799.

Wilson, Richard. Writing History in International Criminal Trials. Cambridge; New York: Cambridge University Press, 2011. 